九州大学学術情報リポジトリ

Kyushu University Institutional Repository

\title{
Mineralogical and Genetical Study on Alabandite from the Manganese Deposits of Japan
}

Fukuoka, Masato

Faculty of Science, Kyushu University

https://doi.org/10.5109/1546077

出版情報：九州大學理學部紀要：Series D, Geology. 24 (4)，pp.207-251，1981-12-25. Faculty of Science, Kyushu University バージョン：

権利関係 : 
Mem. Fac. Sci., Kyushu Univ., Ser. D. Geol., Vol. XXIV, No. 4, pp. 207-251, text-figs. 1-12, tables 1-3, December 25, 1981

\title{
Mineralogical and Genetical Study on Alabandite from the Manganese Deposits of Japan
}

\author{
Masato FuKUOKA
}

\begin{abstract}
The modes of occurrence, parageneses, and chemical composition of alabandite and associated minerals in sixty-three samples from nineteen manganese deposits in Japan are described on the basis of microscopic observation, X-ray powder diffraction, and electron probe microanalysis.

From the results obtained, the parageneses and chemical composition of alabandite are grouped into three types by the differences of the modes of occurrence. In the first type, alabandite occurs in coarse-grained rhodochrosite ore in Tertiary vein-type deposits with $\mathrm{FeS}$ content of 0.6 to $5.8 \mathrm{~mol} \%$. In the second type, alabandite is dispersed in fine-grained rhodochrosite ore in unmetamorphosed bedded-type deposits with FeS range of 0.2 to $6.6 \mathrm{~mol} . \%$. In the third type, alabandite occurs abundantly in manganese silicates and oxides ore in thermally metamorphosed bedded-type deposits and has 0.3 to $13.5 \mathrm{~mol}$.\% FeS. The two bedded-type deposits were formed in Paleozoic to Mesozoic age.

In the second and third types, the FeS content in alabandite is closely correlated to the kinds of the associated minerals. Namely, the FeS content in alabandite associated with manganese oxides ore, tephroite ore, and rhodonite ore is less than $2 \mathrm{~mol} . \%, 4 \mathrm{~mol} . \%$, and $13.5 \mathrm{~mol} \%$, respectively. Especially in the third type, the above data indicate that FeS content of alabandite generally increases from the central to the peripheral parts of ore bodies.

This variation of the FeS content is explained not only by the differences in the distribution ratios of iron between alabandite and associated manganese oxides and silicates but also by the introduction of iron accompanied with sulfur into ore body during thermal metamorphism.

Moreover, considering the stability field of alabandite which was thermochemically calculated by using the selected principal reactions, it seems that alabandite could be frequently found in nature.
\end{abstract}

\section{Content}

Page

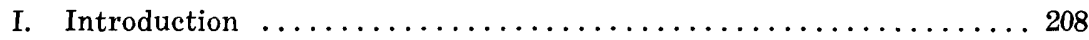

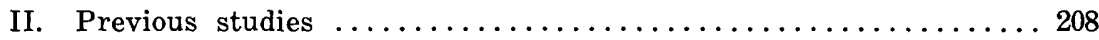

III. Locality and manganese deposits $\ldots \ldots \ldots \ldots \ldots \ldots \ldots \ldots \ldots \ldots$

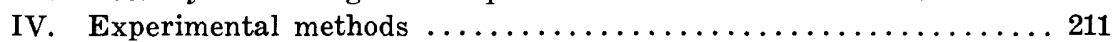

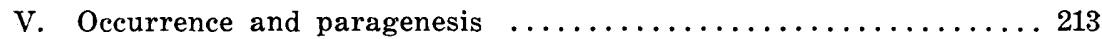

VI. Compositional relation between alabandite and associated

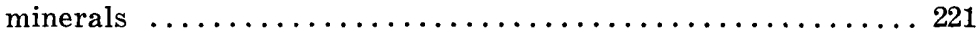

VII. Genetic environment of alabandite $\ldots \ldots \ldots \ldots \ldots \ldots \ldots \ldots \ldots 232$

Manuscript received June 30, 1981. 


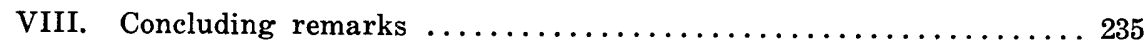

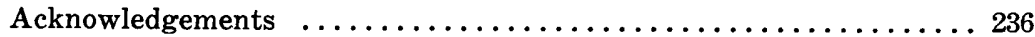

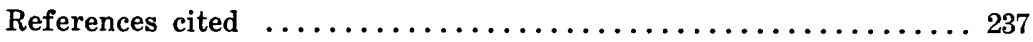

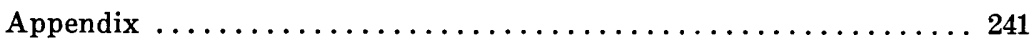

\section{Introduction}

Four synthetic phases of binary manganese-sulfur have been known. They are $\alpha$-MnS (cubic, NaCl-type structure), $\beta$ - MnS (cubic, sphalerite-type structure), $\beta$-MnS (hexagonal, wurtzite-type structure), and $\mathrm{MnS}_{2}$ (cubic, pyrite-type structure) (WYCKoFf, 1921; SchNAASE, 1933; MEHMED and Haraldsen, 1938). Only $\alpha-\mathrm{MnS}$ and $\mathrm{MnS}_{2}$ are stable in nature and are called alabandite and hauerite, respectively. Hauerite has never been found in manganese deposits but occurs rarely in sulfur deposits, because it is stable under sulfur vapor pressures higher than approximately that compatible with the sulfur condensation curve (BILTZ and WIECHMANN, 1936; BARTON and SkINNER, 1979). Alabandite has been known to occur widely as a minor constituent in most manganese deposits in Japan, although it was formerly considered as an uncommon mineral.

Alabandite is now the common and the only mineral in the manganesesulfur system in the manganese deposits. Therefore, it should be possible to use alabandite as an indicator of $\mathrm{fs}_{2}$ (sulfur fugacity) which reflects the effect of the other predominant parameters (e.g., temperature, $\mathrm{fo}_{2}, \mathrm{fco}_{2}$, etc.) controlling mineral formation in the process of manganese ore formation. However, no genetical studies of natural alabandite have been conducted except for the brief reports of HewetT and Rove (1930), WATANABE (1939), and Watanabe and KIMURA (1954).

In this paper, a large number of alabandite samples from Paleozoic to Mesozoic bedded-type and Tertiary vein-type manganese deposits in Japan are described with respect to the mode of occurrence, chemical composition, and paragenetic relation in order to clarify the genetical environment of alabandite.

\section{Previous studies}

Some useful mineralogical works on natural or synthetic alabandite, especially made in Japan, are briefly reviewed.

\section{A. Natural alabandite}

Alabandite was first named by BeUdANT in 1832. In Japan, it was found for the first time from Oishi mine, Akita Prefecture, by Tsunashirō WADA in 1916. Since then alabandite has been recognized and reported from about 60 manganese mincs in Japan (Table 1).

WATANABE and KimURA (1954) classified alabandite into two types on the bas.s of the mode of occurrence and paragenetic relation. One is epithermal deposit type, i.e., the Tertiary rhodochrosite veins, in which alabandite is assoc a ${ }^{\prime} \in d$ with euhedral or colloformed pyrite, marcasite, quartz, and rhodochrosite and occasionally with gold, silver, lead, or zinc bearing minerals. The other is 
Table 1. List of alabandites reported from Japan.

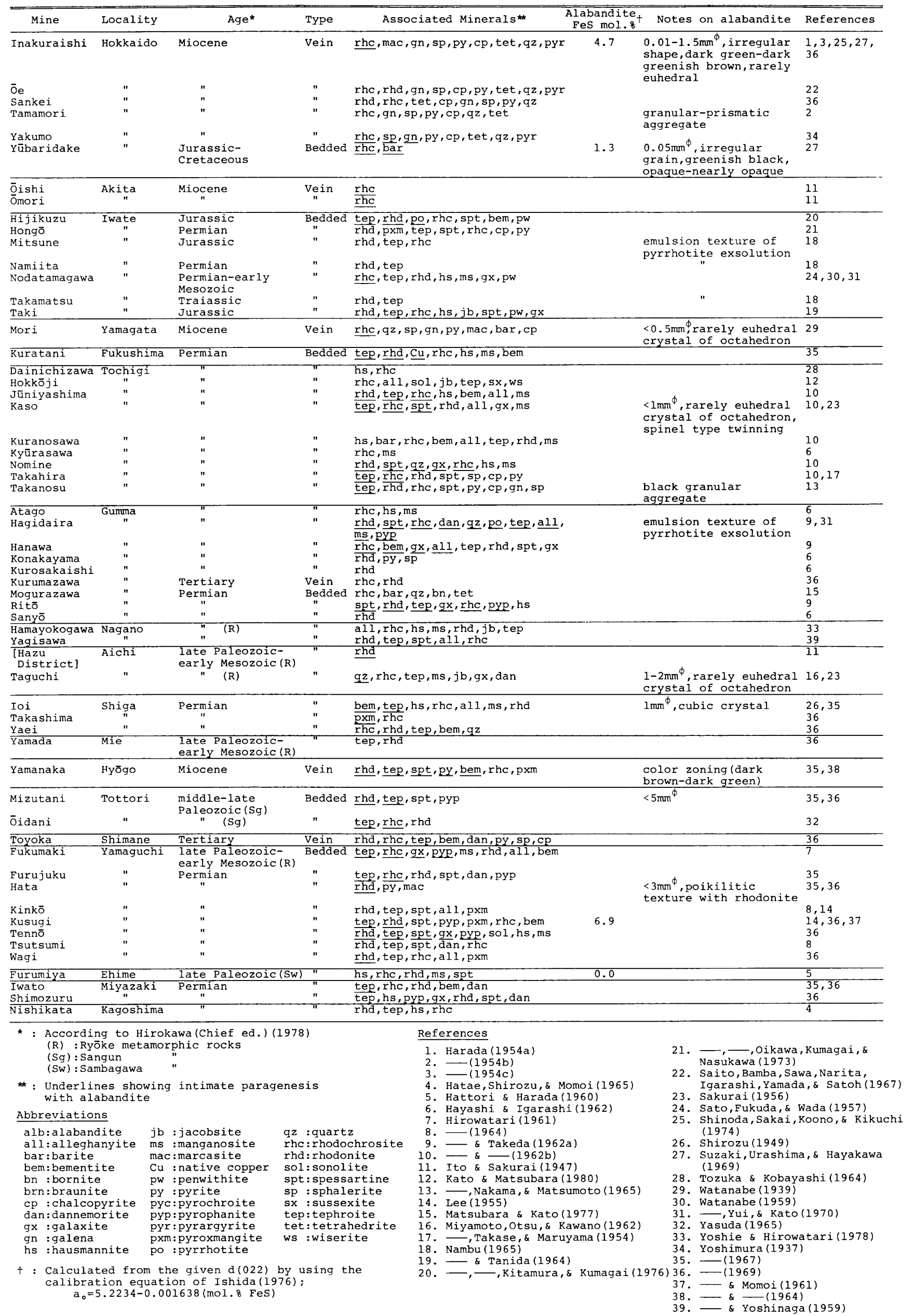


pyrometasomatic deposit type, i.e., the bedded-type manganese deposits in the "Chichibu Paleozoic Formation" metamorphosed highly by intrusion of later granitic rocks, in which alabandite is associated with rhodochrosite, manganese silicates (e.g., rhodonite, tephroite, alleghanyite), and manganese oxides (e.g., hausmannite, manganosite) and commonly includes minute euhedral or granular grains of chalcopyrite, pyrite, and pyrrhotite with the emulsion structure. They have assumed that the former had formed at lower temperature than the latter.

There are a few morphological studies on euhedral alabandite, but it is known to occur very rarely in nature (SHIROzU, 1949; HARADA, 1954a,c; SAKURAI, 1956).

Several chemical composition data of alabandite have been reported, but the analyzed values seem to be unreliable because the analyzed samples were impure. Therefore, the values of $\mathrm{FeS}$ mol.\% in alabandite calculated from the given $d(022)$ values by using the calibration equation of IsHIDA (1976) are also shown for reference in Table 1 .

\section{B. Synthetic alabandite}

Alabandite does not depart measurably from stoichiometric composition of $\mathrm{MnS}$ and remains stable to about $1610^{\circ} \mathrm{C}$ (HANSEN and ANDERKo, 1960). There

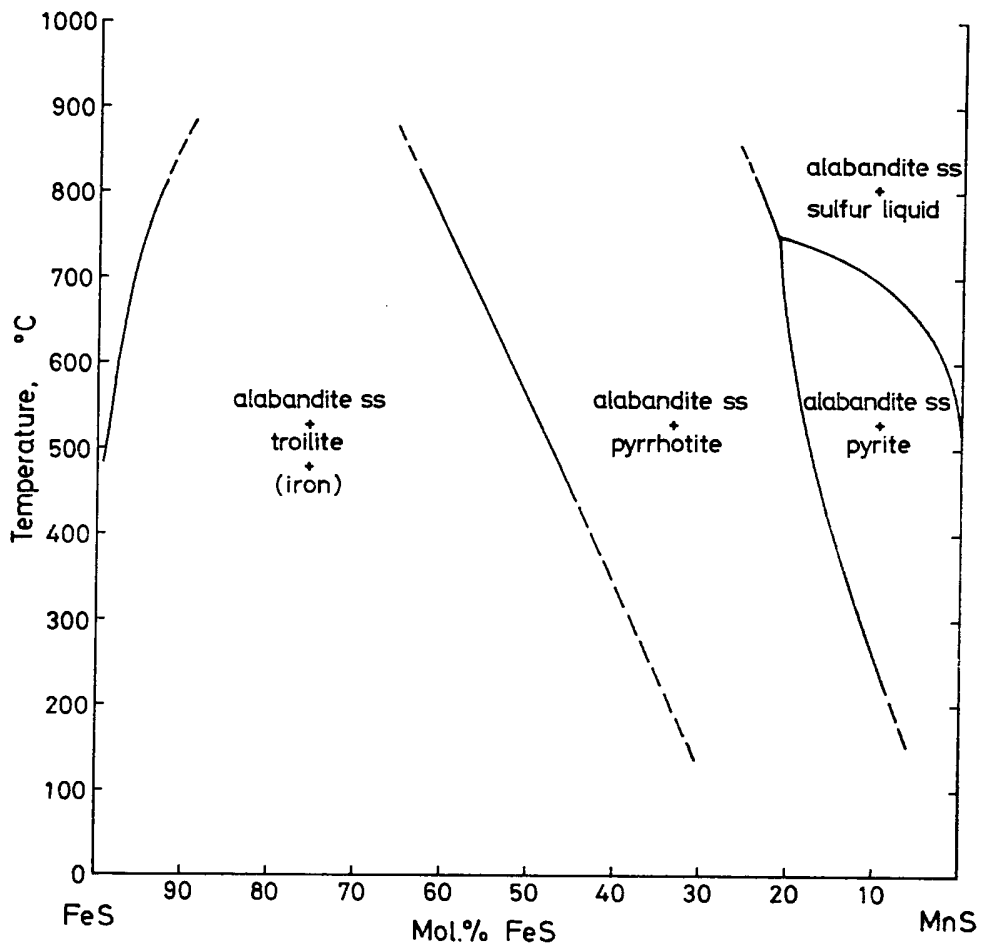

Fig. 1. Composition of alabandite solid solutions in equilibrium with troilite (+iron), pyrrhotite, pyrite, or sulfur liquid after SUGAKI and Kitakaze (1972). 
are several experimental studies of the systems including alabandite, e.g., the system FeS-MnS by SHIBATA (1928) from a standpoint of the steel metallurgy and the system CaS-MgS-MnS-FeS by SkINNER and LUCE (1971) from the mineralogy of enstatite chondrites. The first study for the purpose of direct use in estimating the conditions of ore formation was made by SUGAKI and KITAKAZE (1972) in the system Mn-Fe-S. They have investigated in detail the phase equilibrium relations along the MnS-FeS join of the system by using the rigid and collapsible tube techniques and obtained relation which is very similar to that of the sphalerite solid solution in the system Fe-Zn-S. The gentle slope of the curve of the alabandite+pyrite+pyrrhotite assemblage on a composition-temperature plane shown in Figure 1, which differs from the curve of sphalerite (SCOTT and BARNES, 1971), indicates that the alabandite solvus is useful as a geothermometer. Moreover, IshIDA et al. (1977) have presented the fugacity of $\mathrm{S}_{2}$-composition diagram for the divariant assemblage of pyrrhotite+alabandite in the range $500-800^{\circ} \mathrm{C}$.

\section{Locality and manganese deposits}

In this study, alabandite has been identified in the samples from nineteen localities as shown in Figure 2. Only three of these, i.e., Nakanoyama, Shōwa, and Fukadani mines are new occurrences. The locations of mines, lithofacies of wall rocks, and the major ore minerals are listed in Table 2.

In the Inakuraishi, Mori, and Yamanaka mines, epithermal fissure filling manganese veins occur in the Neogene volcanic field and their major constituents are rhodochrosite.

The Hamayokogawa, Yamada, and Fukumaki mines are located in the Ryōke metamorphic belt. They are Paleozoic to Mesozoic bedded-type manganese deposits and the last two deposits consist mainly of manganese silicates which can be regarded as thermally metamorphosed products by the intrusion of Cretaceous granitic rocks. The deposit of Hamayokogawa mine is situated in the outer zone of the Ryōke metamorphic belt and it is hardly affected by later thermal metamorphism. Major constituents are fine-grained alleghanyite, hausmannite, and rhodochrosite.

The Furumiya mine, as a bedded-type deposit, is found in the Sambagawa metamorphic rocks. The deposit is considered to have been affected by the Neogene volcanism. Although the major constituent of the deposit consists generally of braunite, alabandite occurs in the ores of rhodochrosite, hausmannite, and manganese silicates which partially replace the braunite ore.

The ore deposits of the other twelve mines, belonging to Permian to Jurassic bedded-type deposits, are intercalated in the "Chichibu Paleozoic Formation". The deposits of Hijikuzu, Nodatamagawa, Kaso, Hagidaira, Fukadani, Kusugi, and Tsutsumi mines have been thermally metamorphosed by the intrusion of the Cretaceous granitic rocks and consist mainly of manganese silicate ores. The deposit of Shimozuru mine has suffered presumably the thermal effects by the Neogene granitic intrusion. The major ore is similarly made up of 
$x$ : Vein-type manganese deposit

- : Bedded-type "

1. Inakuraishi

2. Mori

3. Yamanaka

4. Hanawa

5. Nakanoyama

6. Ritō

7. Shōma

8. Hamayokogawa

9. Furumiya

10. Hijikuzu

11. Nodatamagawa

12. Kaso

13. Hagidaira

14. Yamada

15. Fukadani

16. Fukumaki

17. Kusugi

18. Tsutsumi

19. Shimozuru

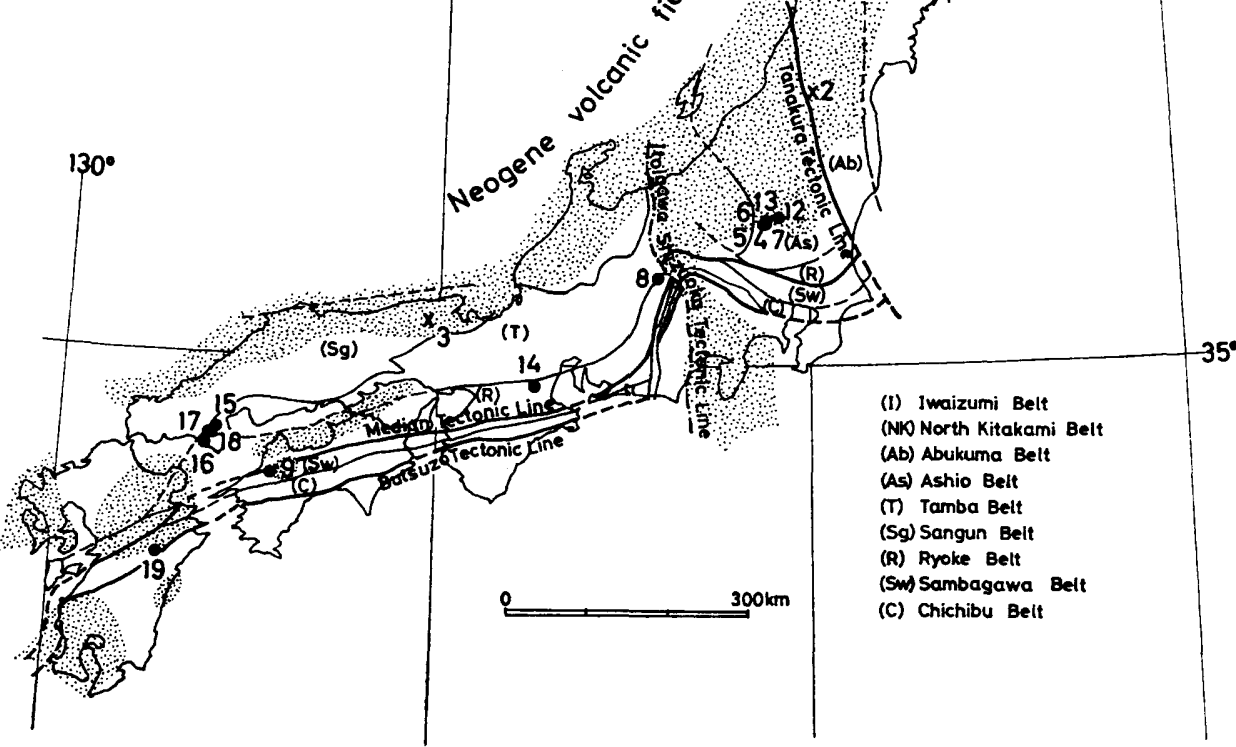

Fig. 2. Location of manganese mines from which samples were taken for this study. Neogene volcanic field and some pre-Neogene geotectonic division are quoted from HIROKAWA (Chief ed.) (1978).

manganese silicates. The deposits of Hanawa, Nakanoyama, Ritō, and Shōwa mines occur in none to weakly metamorphosed sediments and consist mainly of rhodochrosite.

\section{Experimental methods}

All the samples obtained from the above deposits were examined microscopically under transmitted and reflected lights in order to identify alabandite. Then the constituents of the selected samples were identified by means of X-ray 
Table 2. General features of the manganese deposits occurring alabandite used in this study.

\begin{tabular}{|c|c|c|c|c|c|}
\hline Mine & Location & Age & TYpe & Wall rocks & Chief constituents \\
\hline 1. Inakuraishi & $\begin{array}{l}30 \mathrm{~km} \text { W of Otaru City, } \\
\text { Hokkaido Prefecture }\end{array}$ & Miocene & Vein & propylite and tuff breccia & rhc,alb \\
\hline 2. Mori & $\begin{array}{l}28 \mathrm{~km} \mathrm{SW} \text { of Yamagata City, } \\
\text { Yamagata Prefecture }\end{array}$ & $"$ & $"$ & granodiorite & rhe \\
\hline 3. Yamanaka & $\begin{array}{l}17 \mathrm{~km} \mathrm{~S} \text { of Toyooka City, } \\
\text { Hyōgo Prefecture }\end{array}$ & $n$ & $"$ & rhyolitic tuff & rhd, rhe, alb \\
\hline 4. Hanawa & $\begin{array}{l}16 \mathrm{~km} \mathrm{~N} \text { of Kiry } \overrightarrow{\mathrm{u}} \text { City, } \\
\text { Gumma Prefecture }\end{array}$ & Permian & Bedded & massive chert and bedded chert & rhe, bem, pxm \\
\hline 5. Nakanoyama & $\begin{array}{l}15 \mathrm{~km} \mathrm{~N} \text { of Kiryū City, } \\
\text { Gumma Prefecture }\end{array}$ & " & " & " & rhc, bem, all \\
\hline 6. Ritō & $\begin{array}{l}17 \mathrm{~km} N \text { of Kiryū City, } \\
\text { Gumma Prefecture }\end{array}$ & $"$ & $"$ & $"$ & rhc, bem \\
\hline 7. Showa & " & $"$ & $"$ & $"$ & rhe, bem, hs \\
\hline 8. Hamayokogawa & $\begin{array}{l}25 \mathrm{~km} \mathrm{~S} \text { of Matsumoto City, } \\
\text { Nagano Prefecture }\end{array}$ & $" \quad(\mathrm{R})$ & $"$ & ( & all, hs, rhe \\
\hline 9. Furumiya & $\begin{array}{l}15 \mathrm{~km} \text { S of Matsuyama City, } \\
\text { Ehime Prefecture }\end{array}$ & $\begin{array}{l}\text { late Paleozoic } \\
(\mathrm{Sw}) \text {. }\end{array}$ & $"$ & $\begin{array}{l}\text { piemontite quartz schist and } \\
\text { quartzite }\end{array}$ & brn, rhd, rhc, hs, alb \\
\hline 10. Hijikuzu & $\begin{array}{l}\text { 16km NW of Miyako City, } \\
\text { Iwate Prefecture }\end{array}$ & Jurassic & $"$ & $\begin{array}{l}\text { hornfels of massive chert and } \\
\text { bedded chert }\end{array}$ & pxm, rhd, tep, brn \\
\hline 11. Nodatamagawa & $\begin{array}{l}\text { 16km SE of Kuji City, } \\
\text { Iwate Prefecture }\end{array}$ & $\begin{array}{l}\text { Permian-early } \\
\text { Mesozoic }\end{array}$ & $"$ & " & rhd, tep, hs, pyc \\
\hline 12. Kaso & $\begin{array}{l}12 \mathrm{~km} \text { NW of Kanuma City, } \\
\text { Tochigi Prefecture }\end{array}$ & Permian & $"$ & $"$ & rhc, tep, rhd \\
\hline 13. Hagidaira & $\begin{array}{l}19 \mathrm{~km} \mathrm{~N} \text { of Kiryū City, } \\
\text { Gumma Prefecture }\end{array}$ & $"$ & $"$ & 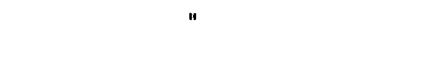 & rhd, alb, tep \\
\hline 14. Yamada & $\begin{array}{l}25 \mathrm{~km} \text { w of Tsu City, } \\
\text { Mie Prefecture }\end{array}$ & $\begin{array}{l}\text { late Paleozoic- } \\
\text { early Mesozoic }(R)\end{array}$ & " & $\begin{array}{l}\text { schistose hornfels of bedded } \\
\text { chert }\end{array}$ & rhd, tep, alb \\
\hline 15. Fukadani & $\begin{array}{l}16 \mathrm{~km} \text { W of Iwakuni City, } \\
\text { Yamaguchi Prefecture }\end{array}$ & Permian & $"$ & hornfels of massive chert & rhd, pxm, rhe \\
\hline 16. Fukumaki & $\begin{array}{l}6 \mathrm{~km} \mathrm{E} \text { of Kudamatsu City, } \\
\text { Yamaguchi Prefecture }\end{array}$ & $\begin{array}{l}\text { late Paleozoic- } \\
\text { early Mesozoic }(R)\end{array}$ & $"$ & $\begin{array}{l}\text { hornfels of biotite schist and } \\
\text { massive chert }\end{array}$ & rhd, tep, alb \\
\hline 17. Kusugi & $\begin{array}{l}23 \mathrm{~km} \text { wSW of Iwakuni City, } \\
\text { Yamaguchi Prefecture }\end{array}$ & Permian & $"$ & $\begin{array}{l}\text { hornfels of massive chert and } \\
\text { bedded chert }\end{array}$ & rhd, tep, spt, alb \\
\hline 18. Tsutsumi & $\begin{array}{l}\text { 18km SW of Iwakuni City, } \\
\text { Yamaguchi Prefecture }\end{array}$ & $"$ & $"$ & " & rhd, pxm, tep, spt \\
\hline 19. Shimozuru & $\begin{array}{l}30 \mathrm{~km} \mathrm{NW} \text { of Nobeoka City, } \\
\text { Miyazaki Prefecture }\end{array}$ & " & $"$ & hornfels of massive chert & tep, rhd, alb, dan \\
\hline
\end{tabular}

Abbreviations are the same as shown in Table 1. 
diffraction. Chemical composition of alabandite and the associated minerals were quantitatively determined by electron probe microanalysis.

The quantitative analyses were carried out in most cases for $\mathrm{Mn}, \mathrm{Fe}$, and $\mathrm{S}$ in alabandite, for $\mathrm{Zn}, \mathrm{Fe}, \mathrm{Mn}$, and $\mathrm{S}$ in sphalerite, for $\mathrm{Mn}, \mathrm{Fe}, \mathrm{Ca}, \mathrm{Mg}, \mathrm{Al}$, $\mathrm{Ti}$, and $\mathrm{Si}$ and, when necessary, $\mathrm{Na}$ and $\mathrm{K}$ in oxides and silicates, and for $\mathrm{Mn}, \mathrm{Fe}, \mathrm{Ca}$, and $\mathrm{Mg}$ in carbonates.

The analytical conditions of the electron probe microanalyser (Japan Electron Optics Laboratory Co., Ltd., Model JXA-5A with $40^{\circ}$ take-off angle) were as follows: for sulfides, the accelerating voltage, specimen current, and electron beam diameter were $20 \mathrm{kV}, 0.015 \mu \mathrm{A}$ (on pure iron), and 2 to $3 \mu$, respectively. The characteristic X-rays used were $\mathrm{S}-\mathrm{K} \alpha$ (analysing crystal: PET, standard specimen: synthetic $\mathrm{MnS}$ or $\mathrm{CuFeS}_{2}$ ), $\mathrm{Mn}-\mathrm{K} \alpha$ ( $\mathrm{LiF}$, synthetic $\mathrm{MnS}$ ), $\mathrm{Fe}-\mathrm{K} \alpha$ ( $\mathrm{LiF}$, synthetic $\mathrm{FeS}$ or $\mathrm{CuFeS}_{2}$ ), and $\mathrm{Zn}-\mathrm{K} \alpha$ (LiF, metal $\mathrm{Zn}$ ). For oxides, silicates, and carbonates, the accelerating voltage, specimen current, and electron beam diameter were $15 \mathrm{kV}, 0.015 \mu \mathrm{A}$ (on pure iron), and 1 to $2 \mu$, respectively. The characteristic $\mathrm{X}$-rays employed were $\mathrm{Mn}-\mathrm{K} \alpha$ ( $\mathrm{LiF}$, natural $\mathrm{MnO}$ ), $\mathrm{Fe}-\mathrm{K} \alpha$ ( $\mathrm{LiF}$, synthetic $\mathrm{Fe}_{2} \mathrm{O}_{3}$ ), $\mathrm{Ca}-\mathrm{K} \alpha$ (PET, synthetic $\mathrm{CaSiO}_{3}$ ), $\mathrm{Mg}-\mathrm{K} \alpha$ (KAP, synthetic $\mathrm{MgO}$ ), $\mathrm{Al}-\mathrm{K} \alpha$ (RAP, synthetic $\mathrm{Al}_{2} \mathrm{O}_{3}$ ), Ti-K $\alpha$ ( $\mathrm{LiF}$, synthetic $\left.\mathrm{TiO}_{2}\right), \mathrm{Si}-\mathrm{K} \alpha$ (RAP, synthetic $\mathrm{CaSiO}_{3}$ ), Na-K $\alpha$ (RAP, natural $\mathrm{NaAlSi}_{3} \mathrm{O}_{8}$ ), and $\mathrm{K}-\mathrm{K} \alpha$ (PET, natural $\mathrm{KAlSi}_{3} \mathrm{O}_{8}$ ). Corrections based on the Sweatman and Long method (ZAF method) were used for sulfides and the Bence and Albee method for oxides, silicates, and carbonates.

\section{Occurrence and paragenesis}

The mole percent $\mathrm{FeS}$ and the grade of pyrrhotite exsolution in alabandite, and the relative amount of principal constituents in the alabandite specimens are summarized in Figure 3. The amount of other contents except for $\mathrm{MnS}$ and $\mathrm{FeS}$ in alabandite is generally so small that the chemical composition of alabandite can be expressed as the mol. $\% \mathrm{FeS}$. The result shows that the $\mathrm{FeS}$ content in alabandite varies continuously from 0.2 to a maximum of $13.5 \mathrm{~mol} \%$ and has intimate relations with the coexisting minerals. The chemical analyses of alabandite are shown in Appendix I-A.

The mode of occurrence, chemical composition, and paragenetic relation of alabandite in each sample are described as follows.

\section{A. Alabandite from vein-type manganese deposits}

In the samples from the vein-type deposits, alabandite is commonly associated with rhodochrosite and quartz, and usually occurs as granular coarse grains with heterogeneous composition. It usually shows no exsolution texture. The FeS content in alabandite is 0.6 to $5.8 \mathrm{~mol} \%$ and the differences among those from three deposits are considerably small.

\section{Inakuraishi mine}

The sample (R.C.) was collected from the point of W50m at 7L of Tsūdō 
vein. It is an aggregate ore of coarse-grained (more than $2 \mathrm{~mm}$ in size) rose pinkish rhodochrosite and dark brownish alabandite, which is associated with small amount of quartz. The sulfides and sulfosalts such as euhedral or subhedral marcasite (partly pyrite), petal-like wurtzite (partly sphalerite), galena, chalcopyrite, miargyrite, pyrargyrite, Mn-bearing fizelyite, Mn·Ag-bearing tetrahedrite, diaphorite, and Mn-bearing andorite occur around the boundaries between alabandite and rhodochrosite or quartz grains. Stibnite occurs as veinlets cutting these minerals, but is invaded by marcasite veinlets. Although the marcasite and wurtzite are considerably of coarse grains up to $1 \mathrm{~mm}$ in size, the other sulfides and the sulfosalts are very fine grains less than $0.1 \mathrm{~mm}$.

Under a polarizing microscope, the alabandite frequently shows the color zoning of greenish yellow to reddish brown and no exsolution texture. The FeS content varies extensively from 0.6 to $5.2 \mathrm{~mol} \%$ in accordance with the variations of color.

\section{Mori mine}

The sample (621080) is composed mainly of light pinkish and dark brownish rhodochrosite (up to $2 \mathrm{~mm}$ in size) associated with small amount of quartz. The dark brownish one includes abundantly fine grains of alabandite and euhedral marcasite (partly pyrite) less than $0.1 \mathrm{~mm}$ in size. Alabandite is out of contact with quartz and has no exsolution texture.

The composition of alabandite varies considerably among the individual grains but is fairly constant within one grain with the range of 1.0 to $5.8 \mathrm{~mol} \%$ FeS.

\section{Yamanaka mine}

Sample (A) is composed mainly of coarse-grained alabandite up to $1 \mathrm{~cm}$. The veinlets of fluorite which is associated with accessory rhodochrosite, rhodonite, and quartz cut through alabandite, and euhedral pyrite occurs in small amount along the boundaries.

Sulfides such as sphalerite, galena, and chalcopyrite are present as minor constituents in or around the grains of alabandite. Although sphalerite shows no exsolution, alabandite contains a little pyrrhotite grains as minute emulsions.

The FeS content of alabandite is 2.4 to $4.4 \mathrm{~mol} . \%$.

\section{B. Alabandite from bedded-type manganese deposits}

In the samples from the bedded-type deposits, alabandite is associated with a large variety of manganese minerals compared to the vein-type deposits. The composition generally has a tendency to vary in accordance with the kinds of associated minerals. The tendency is evident especially in the case of ores strongly affected by thermal metamorphism. This type of deposits can be subdivided into two cases according to their metamorphic grades.

\section{B.1. None to weakly metamorphosed deposits}

In the deposits which are not metamorphosed or very weakly affected, the 


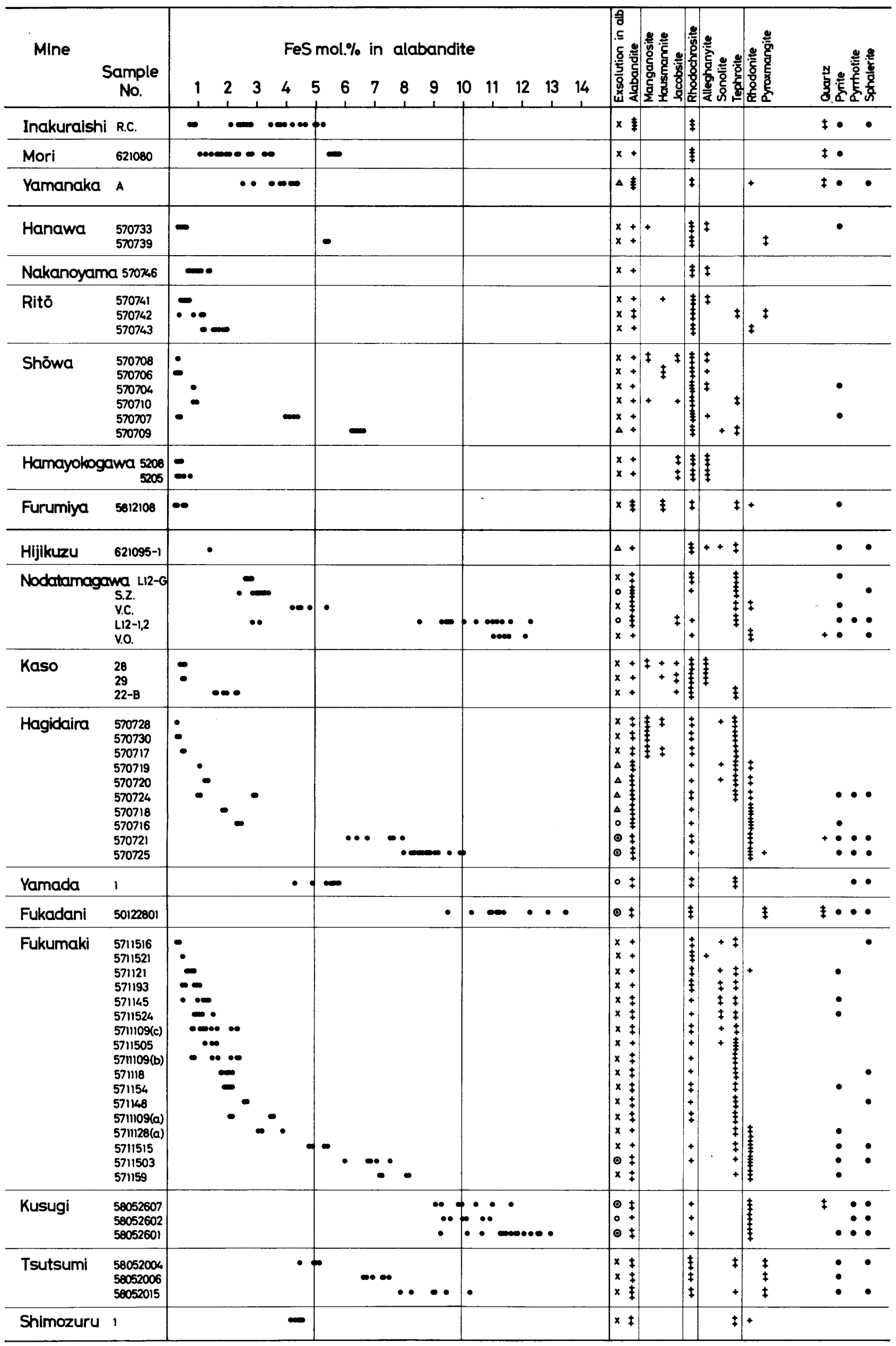

Fig. 3. Relation between mineral assemblage and chemical composition of alabandite in the manganese mines in this study.

+ : relative amount of alabandite and associated minerals, and the more number in increase of abundance.

$\odot, \bigcirc, \triangle, \times$ : grade of exsolution in alabandite, large, medium, rare, and none, respectively.

- : showing the presence of pyrite, pyrrhotite, or sphalerite. 
ore generally consists mainly of rhodochrosite associated with insignificant amount of alabandite. Moreover the iron content of alabandite is lower than that in highly metamorphosed ores.

\section{Hanawa mine}

Sample (570733) is composed mainly of fine-grained rhodochrosite and alleghanyite associated with small amounts of manganosite, galaxite, and bementite. The sample (570739) consists mainly of rhodochrosite and pyroxmangite and is associated with small amounts of spessartine and pyrophanite. Very minor amount of alabandite is disseminated in the rhodochrosite ores. Alabandite takes granular or irregular shape and is up to $0.2 \mathrm{~mm}$ in size. It contains no exsolved mineral.

The FeS content of alabandite is 0.3 to $0.6 \mathrm{~mol} \%$ for the sample (570733), and 5.3 to $5.4 \mathrm{~mol} . \%$ for (570739).

\section{Nakanoyama mine}

Sample (570746) is composed mainly of fine-grained rhodochrosite and alleghanyite and is associated with small amount of galaxite. Minor amount of alabandite occurs in rhodochrosite as dispersed grains which are granular and less than $0.1 \mathrm{~mm}$ in size. It shows no exsolution texture.

The FeS content in alabandite ranges from 0.6 to $1.4 \mathrm{~mol} . \%$.

\section{Ritō mine}

Samples (570741, 570742, 570743) are composed mainly of rhodochrosite associated with various amounts of tephroite, alleghanyite, rhodonite, pyroxmangite, spessartine, bementite, hausmannite, and small amounts of galaxite, pyrophanite, and penwithite. Minor amount of alabandite whose grains are granular and up to $0.4 \mathrm{~mm}$ in size and have no exsolution is disseminated in the fine-grained rhodochrosite. It frequently accompanies minute amount of barite.

The FeS content in alabandite is 0.3 to $2.0 \mathrm{~mol} \%$.

\section{Shōwa mine}

Samples $(570708,570706,570704,570710,570707,570709)$ are composed mainly of fine-grained rhodochrosite associated with various amounts of alleghanyite, tephroite, manganosite, bementite, jacobsite, and small amounts of galaxite, spessartine, hausmannite, sonolite, and pyrophanite. Minor amount of alabandite occurs as dispersed or layered grains in rhodochrosite and in the case of the latter the direction of layers is almost parallel to that of the banded texture in the ore itself. Alabandite is irregular or granular and commonly less than $0.3 \mathrm{~mm}$ in grain size and accompanies minor amounts of barite, pyrite, and invariably Ni-bearing minerals such as millerite, gersdorffite, pentlandite, and breithauptite.

The FeS content in alabandite is 0.2 to $6.6 \mathrm{~mol} \%$. Exsolved pyrrhotite is found in the alabandite from sample (570709) which has the highest FeS content. 


\section{Hamayokogawa mine}

Although the deposit is located in the outer zone of the Ryōke metamorphic belt, it has hardly been affected by the later thermal metamorphism.

The samples $(5208,5205)$ are composed mainly of fine- to medium-grained rhodochrosite and alleghanyite, associated with notable amount of jacobsite and small amounts of bementite and barite. Jacobsite occurs as very minute grains with layered structure. A small amount of alabandite is scattered in rhodochrosite and alleghanyite. It is less than $0.1 \mathrm{~mm}$ in grain size and takes no exsolution.

The FeS content in alabandite is 0.2 to $0.7 \mathrm{~mol} . \%$.

\section{Furumiya mine}

The deposit is found in the Sambagawa metamorphic belt. The ore containing alabandite shows rather unusual occurrence, which is described below.

Sample (5812108) which is considered to have formed by reduction of braunite-quartz ore, shows zonal structure forming rings which are several centimeters across. They are composed of hausmannite-rhodochrosite-alabanditetephroite-rhodonite-quartz from the center outward. The zone of alabandite is associated with barite, euhedral spessartine, and small amounts of galena, pyrite, and chalcopyrite. Alabandite is up to $0.3 \mathrm{~mm}$ in size, and has irregular myrmekitic texture but no exsolution.

The FeS content in alabandite is 0.2 to $0.6 \mathrm{~mol} . \%$.

\section{B.2. Moderately to highly metamorphosed deposits}

In the deposits moderately to highly affected by thermal metamorphism, the ore generally consists of manganese silicates associated with considerable amount of alabandite. Moreover the iron sulfides are frequently and abundantly accompanied with it. The iron content in the alabandite is relatively higher than that from unmetamorphosed deposits.

\section{Hijikuzu mine}

Sample (621095-1) comprises coarse-grained granoblastic rhodochrosite and tephroite, and is associated with small amounts of alleghanyite and sonolite. Rhodochrosite is turbid. Manganese silicates are almost all replaced by bementite. Alabandite commonly occurs as granoblastic aggregates with rhodochrosite and tephroite, but partly as veinlets. The former contains little emulsions of pyrrhotite and chalcopyrite, but the latter no exsolved minerals. It rarely shows optical anisotropy under the transmitted light. Minor amount of pyrite also occurs as veinlets cutting these minerals.

The FeS content in alabandite is $1.4 \mathrm{~mol} . \%$.

\section{Nodatamagawa mine (Kirihata deposit)}

Samples (V.C., V.O.) were collected from the point of 5500 at $0 \mathrm{~mL}$ of Kirihata deposit. The sample (V.C.) is composed mainly of irregular grained (up to $0.3 \mathrm{~mm}$ in size) alabandite and spessartine, associated with tephroite, rhodonite, and small amounts of Ba-bearing phlogopite, pyrophanite, chalcopyrite, 
pyrite, and cobaltite. The sample (V.O.) is composed mainly of irregular grained rhodonite around $0.1 \mathrm{~mm}$ in size with small amounts of spessartine, pyrophanite, and huebnerite. Sulfides occur along the grain boundaries of rhodonite. They commonly accompany turbid rhodochrosite, and consist of pyrite, marcasite, chalcopyrite, sphalerite, and alabandite. Sphalerite contains lamellar or dotted grains of chalcopyrite, pyrrhotite, and pyrite. In both samples, alabandite has no exsolution texture. FeS content is 4.2 to $5.4 \mathrm{~mol} \%$ for the former, and 11.0 to $12.1 \mathrm{~mol} \%$ for the latter.

Sample (L12-G) is composed mainly of granoblastic (around $0.3 \mathrm{~mm}$ in size) rhodochrosite, tephroite, and alabandite, associated with minor amounts of galaxite, pyrophanite, and pyrite. Alabandite contains the content of 2.6 to $2.9 \mathrm{~mol} . \% \mathrm{FeS}$ and has no exsolution.

Sample (S.Z.) is composed mainly of granoblastic (around 1 to $2 \mathrm{~mm}$ in size) tephroite and alabandite associated with small amounts of galaxite, rhodochrosite, and bementite. Minor amounts of sulfides such as sphalerite, chalcopyrite, and niccolite occur along the grain boundaries of alabandite. Although sphalerite has no exsolution, alabandite contains small amount of emulsions of pyrrhotite. FeS content in alabandite is in the range of 2.4 to $3.4 \mathrm{~mol} . \%$.

Sample (L12-1,2) is massive aggregate ore composed of alabandite, pyrrhotite, and Mn-bearing magnetite around $0.3 \mathrm{~mm}$ in size. They accompany tephroite, chalcopyrite, pyrite, and small amounts of rhodochrosite, spessartine, jacobsite, bementite, pyrophanite, and minor amounts of sphalerite and scheelite. The boundaries and rims between pyrrhotite and Mn-bearing magnetite grains are commonly replaced by pyrite in part and very rarely by hematite. Alabandite usually shows the exsolution texture of pyrrhotite emulsions. FeS content in alabandite varies from 2.8 to $12.3 \mathrm{~mol} . \%$.

\section{Kaso mine}

Samples $(28,29,22-\mathrm{B})$ are composed mainly of fine-grained rhodochrosite and alleghanyite associated with tephroite, jacobsite, hausmannite, manganosite, bementite, and galaxite. Small amount of alabandite occurs as fine and granular grains scattered in these minerals. It has no exsolution texture.

The FeS content in alabandite is 0.4 to $2.4 \mathrm{~mol} \%$.

\section{Hagidaira mine}

The samples can be subdivided into three types according to the major constituents.

\section{(1) Rhodochrosite-manganosite ore (570728, 570730, 570717)}

The ore consists of alternating two bands in each thickness of several millimeters and one of which is composed mainly of manganosite, rhodochrosite, alabandite, and tephroite and the other is of tephroite, rhodochrosite, and galaxite. Manganosite is usually rimmed with very fine-grained hausmannite. Tephroite is frequently accompanied with small amount of sonolite. Alabandite is 0.1 to $0.3 \mathrm{~mm}$ in grain size. It occurs commonly as granular grains and partly 
as veinlets. It is rarely accompanied with chalcopyrite.

The FeS content in alabandite is 0.3 to $0.6 \mathrm{~mol} . \%$.

(2) Tephroite ore $(570719,570720,570724)$

The ore shows the banded structure as a whole and is composed mainly of granoblastic alabandite and tephroite associated with rhodonite, sonolite, galaxite, and pyrophanite. Tephroite is partly replaced with bementite. Alabandite is occasionally accompanied with turbid rhodochrosite, and small amounts of pyrite, pyrrhotite, sphalerite, and chalcopyrite. It is 0.1 to $1 \mathrm{~mm}$ in grain size and has minute emulsions of pyrrhotite as a product of exsolution.

The FeS content in alabandite is 1.0 to $3.0 \mathrm{~mol} \%$.

\section{(3) Rhodonite ore (570718, 570716, 570721, 570725)}

The ore contains the largest quantity of alabandite in this mine, and is composed mainly of alabandite and subhedral coarse-grained (up to $1 \mathrm{~cm}$ in size) rhodonite associated with turbid rhodochrosite, spessartine, bementite, and small amounts of pyroxmangite, quartz, and pyrophanite. Alabandite commonly occurs as disklike or spheroidal aggregates usually associated with small amounts of pyrite, pyrrhotite, chalcopyrite, and sphalerite. It shows irregular grains with 0.3 to $4 \mathrm{~mm}$ across, and commonly contains exsolved product of pyrrhotite.

The FeS content in alabandite is 1.8 to $10.1 \mathrm{~mol} \%$.

\section{Yamada mine}

Sample (1) is composed mainly of granoblastic tephroite, rhodochrosite, and alabandite, and is associated with small amounts of spessartine and pyrophanite. Alabandite is accompanied with minor amounts of pyrrhotite, sphalerite, gersdorffite, and niccolite. It is less than $1 \mathrm{~mm}$ in grain size and has pyrrhotite exsolution.

The FeS content in alabandite is 4.3 to $5.9 \mathrm{~mol} . \%$.

\section{Fukadani mine}

Sample (50122801) is composed of coarse-grained pyroxmangite, rhodochrosite, and quartz associated with small amounts of spessartine, pyrophanite, and huebnerite. Alabandite is commonly accompanied with pyrrhotite, chalcopyrite, pyrite, sphalerite, gersdorffite, and niccolite. It occurs as scattered grains less than $1 \mathrm{~mm}$ in size and also contains many pyrrhotite exsolution.

The FeS content in alabandite is $\mathbf{9 . 5}$ to $\mathbf{1 3 . 5} \mathrm{mol} \%$ which is a maximum value in this study.

\section{Fukumaki mine}

The samples can be divided into two types according to the major constituents.

(1) Tephroite-rhodochrosite ore $(5711516,5711521,571121,571193,571145$, $5711524,5711109(c), 5711505,5711109(b), 571118,571154,571148,5711109(a))$

The ore is composed usually of tephroite and rhodochrosite associated with 
various amounts of alabandite, sonolite, alleghanyite, spessartine, galaxite, rhodonite, Mn-bearing amphibole, bementite, pyrophanite, and welinite. Alabandite is frequently accompanied with small amounts of pyrite, sphalerite, and Ni-Co-As-S minerals. It has irregular or granular shape with up to $1 \mathrm{~mm}$ in grain size and has no exsolution product.

The FeS content in alabandite is 0.3 to $3.6 \mathrm{~mol} . \%$.

\section{(2) Rhodonite ore $(5711128(a), 5711515,5711503,571159)$}

The ore is composed generally of rhodonite associated with alabandite, tephroite, rhodochrosite, spessartine, pyrophanite, and bementite. Alabandite is accompanied with small amounts of pyrite, sphalerite, and Ni-Co-As-S minerals. It is irregular or granular in shape and is up to $1 \mathrm{~mm}$ in grain size. It has no exsolution except in sample (5711503).

The FeS content in alabandite is 3.0 to $8.2 \mathrm{~mol} . \%$.

\section{Kusugi mine}

Samples $(58052607,58052602,58052601)$ are composed mainly of very coarsegrained (up to $2 \mathrm{~cm}$ in size) rhodonite in which alabandite is scattered, associated with small amounts of spessartine, rhodochrosite, pyrophanite, and quartz. Alabandite is up to $3 \mathrm{~mm}$ in grain size and is commonly accompanied with sphalerite, pyrrhotite which is partly replaced by pyrite, chalcopyrite, and arsenopyrite. Sphalerite has no exsolution texture, but alabandite contains exsolved pyrrhotite up to $50 \mu$ in grain size, which is the largest in this study and occasionally shows subhedral forms.

The $\mathrm{FeS}$ content in alabandite is 9.1 to $13.0 \mathrm{~mol} \%$.

\section{Tsutsumi mine}

Samples $(58052004,58052006,58052015)$ are composed mainly of tephroite, rhodochrosite, and pyroxmangite associated with spessartine, pyrophanite, and rarely with small amount of huebnerite. Alabandite is irregular or granular in shape and less than $0.3 \mathrm{~mm}$ across, and forms a thin band. It is commonly acompanied with minor amounts of pyrite, sphalerite, chalcopyrite, gersdorffite, and niccolite. No exsolution is found in the alabandite.

The FeS content in alabandite ranges from 4.5 to $10.3 \mathrm{~mol} \%$.

\section{Shimozuru mine}

Sample (1) is composed mainly of spessartine, tephroite, and alabandite whose grain sizes are about $0.1 \mathrm{~mm}$, associated with rhodonite, tirodite, and phlogopite. Alabandite is irregular or granular in grain shape and is accompanied with minor amount of chalcopyrite. It does not have exsolution texture.

The FeS content in alabandite is 4.2 to $4.7 \mathrm{~mol} . \%$.

\section{Summary}

The characteristics of the modes of occurrence, paragenetic relations, and chemical composition of alabandite from each deposit in this study are summarized in Table 3. 
Table 3. Summary of the modes of occurrence, paragenetic relations, and chemical composition of alabandite.

\begin{tabular}{|c|c|c|c|c|c|c|c|c|c|}
\hline & $\begin{array}{c}\text { Grade } \\
\text { of } \\
\text { thermal } \\
\text { metamorphism } \\
\end{array}$ & Mine & $\begin{array}{l}\text { Associated } \\
\text { minerals* }\end{array}$ & $\begin{array}{l}\text { Fes mol. } \\
\text { in alb }\end{array}$ & $\begin{array}{l}\text { Amount } \\
\text { of } a l b\end{array}$ & $\begin{array}{c}\text { Exsolution } \\
\text { in alb }\end{array}$ & py & po & $\begin{array}{l}\mathrm{Ni}-\mathrm{Co}- \\
\text { As-S- } \\
\text { minerals }\end{array}$ \\
\hline \multicolumn{2}{|l|}{$\begin{array}{l}\text { Vein-type } \\
\text { (Tertiary) }\end{array}$} & $\begin{array}{l}\text { Inakuraishi } \\
\text { Mori } \\
\text { Yamanaka }\end{array}$ & $\begin{array}{l}\text { rhc } \\
\text { qz } \\
\text { (rhd) }\end{array}$ & $0.6-5.8$ & $\ddagger$ & $\mathbf{x}$ & o & $\mathbf{x}$ & $x$ \\
\hline \multirow{5}{*}{$\begin{array}{l}\text { Bedded-type } \\
\text { (Mesozoic } \\
\text {-Paleozoic) }\end{array}$} & \multirow[b]{2}{*}{$\begin{array}{l}\text { None } \\
\text {-weak }\end{array}$} & \multirow{2}{*}{$\begin{array}{l}\text { Hanawa } \\
\text { Nakanoyàma } \\
\text { Ritō } \\
\text { Shōwa } \\
\text { Hamayokogawa } \\
\text { Furumiya }\end{array}$} & $\begin{array}{l}\text { rhc } \\
\text { ms and/or hs } \\
\text { (all) } \\
\text { (tep) } \\
\text { (jb) }\end{array}$ & $0.2-0.9$ & + & $x$ & $x$ & $x$ & $\Delta$ \\
\hline & & & $\begin{array}{l}\text { rhc } \\
\text { (ali) } \\
\text { (tep) } \\
\text { (pxm) } \\
\text { (rhd) } \\
(\text { jb) }\end{array}$ & $0.2-6.6$ & + & $\mathrm{x}$ & $\mathbf{x}$ & $x$ & $\Delta$ \\
\hline & \multirow{3}{*}{$\begin{array}{l}\text { Moderate } \\
\text {-strong }\end{array}$} & \multirow{3}{*}{$\begin{array}{l}\text { Hijikuzu } \\
\text { Nodatamagawa } \\
\text { Kaso } \\
\text { Hagidaira } \\
\text { Yamada } \\
\text { Fukadani } \\
\text { Fukumaki } \\
\text { Kusugi } \\
\text { Tsutsumi } \\
\text { Shimozuru }\end{array}$} & $\begin{array}{c}\text { ms and/or hs } \\
\text { rhc } \\
\text { (ali) } \\
\text { (tep) } \\
\text { (jb) } \\
\end{array}$ & $0.3-0.6$ & $\ddagger$ & $x$ & $\mathbf{x}$ & $\mathrm{x}$ & $\Delta$ \\
\hline & & & $\begin{array}{l}\text { tep } \\
\text { rhc } \\
\text { (sol) } \\
\text { (all) } \\
(j b)\end{array}$ & $0.3-3.6^{\dagger}$ & $\ddagger$ & $\Delta$ & $\Delta$ & $\mathrm{x}$ & $\Delta$ \\
\hline & & & $\begin{array}{l}\text { rhd and/or pxm } \\
\text { (tep) } \\
\text { (rhc) } \\
\text { (qz) } \\
\text { (sol) }\end{array}$ & $0.6-13.5$ & $\ddagger$ & 0 & 0 & 0 & $\Delta$ \\
\hline
\end{tabular}

* : The minerals parenthesized do not always coexist in an ore body.

+ : except for the sample of Nodatamagawa $(112-1,2)$ Abbreviations are the same as shown in Table 1.
+ : the more number in increase of abundance

$0, \Delta, x$ : grade of exsolution in alabandite, abundant, common, and rare, abundance of minerals, large, 
Because alabandite from the vein-type deposits generally has heterogeneous composition not only within one grain but among different grains and contains no exsolution products, it is interpreted to have preserved the conditions of the ore-forming process to a considerable degree. Moreover, it is considered that the stability field of alabandite will probably be determined by the $\mathrm{fco}_{2}, \mathrm{fo}_{2}$, and $\mathrm{fs}_{2}$ which controll the reactions among rhodochrosite, alabandite, and rhodonite during ore deposition.

In the bedded-type deposits which have not been affected substantially by thermal metamorphism, the sulfur-bearing minerals occurring in the ore bodies are usually very small amounts of alabandite, barite, and Ni-Co-As-S minerals. Thus, it implies that the amount of sulfur itself was insufficient when the deposits had been formed. During the course of thermal metamorphism, the amounts of sulfur-bearing minerals, especially alabandite, tend to increase. These facts obviously suggest that the additional sulfur was introduced from the wall rocks. Moreover, with the increase of temperature, the mineral assemblages changed and zonal distribution of ore minerals became more distinct, i.e., Mn-oxide ore (consisting mainly of manganosite and/or hausmannite), tephroite ore, and rhodonite ore (containing pyroxmangite ore) in Table 3 . It seems that the differences in the mineral assemblages in an ore body produced the diverse ranges of $\mathrm{fo}_{2}, \mathrm{fco}_{2}$, and $\mathrm{fs}_{2}$ as buffers in each zone. Consequently, notable variations in the chemical composition of alabandite might reflect the depositional conditions. Alabandite in the highly metamorphosed deposits has generally homogeneous composition in each zone. However, some variations are observed in the composition of alabandite because of extensive exsolution of pyrrhotite during the retrogressive process by annealing.

Judging from the great varieties of the associated minerals and their wide distribution, alabandite is expected to have considerably extensive stability fields. Besides, its chemical composition has characteristic values in relation to its paragenesis and this is taken as an evidence that each mineral assemblage controls the composition of alabandite.

Therefore, the compositional relations between alabandite and the associated sulfides, oxides, silicates, or carbonates are important and the results of the study are reported in the following sections.

\section{Compositional relation between alabandite and associated minerals}

\section{A. Sulfides}

Alabandite in the vein-type deposits is commonly associated with the sulfosalts containing silver, antimony, and so on, while that in the bedded-type deposits with the sulfides containing nickel, cobalt, arsenic, and so on. Sulfides such as pyrite or pyrrhotite, chalcopyrite, sphalerite, and galena occur in both types and the amount of these minerals is usually very small, but they are important as possible indicators of $\mathrm{fs}_{2}$. Sphalerite is particularly useful as an indicator of the chemical environment of ore deposition because its $\mathrm{FeS}$ content 


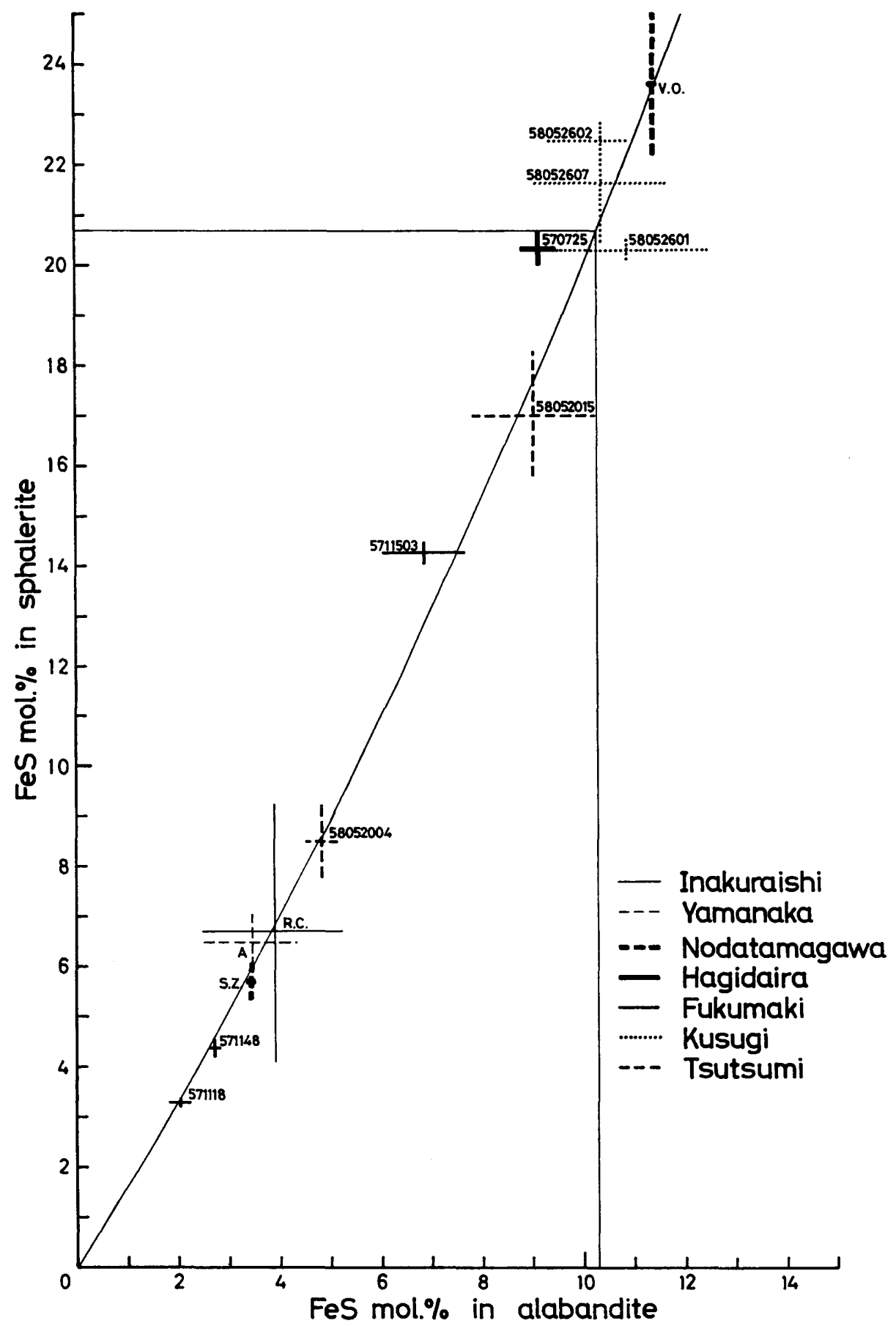

Fig. 4. Relation between iron content in sphalerite and that in alabandite. $20.7 \mathrm{~mol} . \%$ $\mathrm{FeS}$ in sphalerite corresponds to the assemblage, pyrrhotite + sphalerite+pyrite in $\mathrm{Zn}-\mathrm{Fe}-\mathrm{S}$ system below $550^{\circ} \mathrm{C}$ given by SCOTT and BARNES (1971). 
is simultaneously controlled by temperature and $\mathrm{fs}_{2}$.

Therefore, the compositional relation between sphalerite and alabandite in the typical samples is examined.

Sphalerite

As the stability field of sphalerite solid solution and its paragenetic relations in the $\mathrm{ZnS}-\mathrm{MnS}-\mathrm{FeS}$ plane of the $\mathrm{Zn}-\mathrm{Mn}-\mathrm{Fe}-\mathrm{S}$ system in the manganese deposits of Japan are reported by FUKUOKA and HIROWATARI (1981), the relationship between the FeS content in sphalerite and that in alabandite is considered here.

The samples examined amount to thirteen in all, that is, Inakuraishi (R.C.), Yamanaka (A), Nodatamagawa (S.Z., V.O.), Hagidaira (570725), Fukumaki (571118, 571148, 5711503), Kusugi (58052607, 58052602, 58052601), and Tsutsumi $(58052004,58052015)$. The chemical analyses of sphalerite are shown in Appendix I-B. Relationship between the FeS content in sphalerite and alabandite whose grains intimately contact each other is represented in Figure 4.

As realized from the figure, there is a close correlation between the $\mathrm{FeS}$ content in alabandite and that in sphalerite throughout the above samples. This means probably that the variations of the iron content in both minerals have mutually similar tendencies in relation to sulfur fugacity and temperature within the ranges occurring in nature at least in the stability field of pyrite. Thus, it is presumably difficult to determine the ore formation temperature and $\mathrm{fs}_{2}$ at once from the values of the iron content in alabandite and sphalerite in the natural samples. Alabandite which occurs within the stability field of pyrrhotite frequently contains exsolutions of pyrrhotite, even when the associated sphalerite has no exsolution products. This indicates that the reaction rate of the former is comparatively faster than that of the latter. If the value of about $10 \mathrm{~mol} . \%$ is given as the $\mathrm{FeS}$ content in alabandite equilibrating with pyrite and pyrrhotite from Figure 4, the forming temperature of about $250^{\circ} \mathrm{C}$ is obtained by using the data shown in Figure 1. Likewise, if the maximum value of $13.5 \mathrm{~mol} . \% \mathrm{FeS}$ in alabandite obtained in this study is used, the temperature is about $350^{\circ} \mathrm{C}$. Therefore, present composition of alabandite might record the state at about $300^{\circ} \mathrm{C}$ where the exsolution reaction was completed, even though alabandite has primarily formed at higher temperature.

Conversely from the relationship in Figure 4, the iron content in alabandite can be estimated approximately by that in sphalerite in case alabandite does not occur and vice versa.

The other sulfides which bear compositional relations with alabandite are the minerals in the FeAsS-NiAsS-CoAsS system, but the results examined on those minerals have already been reported by FuKuoKA and Hirowatari (1980a).

\section{B. Manganese oxides}

The manganese oxides associated with alabandite consist of manganosite, hausmannite, jacobsite, iwakiite, galaxite, pyrophanite, and Mn-bearing magnetite of which the former three minerals show the most widespread and abundant occurrences in manganese deposits. Although the manganosite rarely forms solid solution in nature, the mineral in the system $\mathrm{Mn}_{3} \mathrm{O}_{4}-\mathrm{Fe}_{3} \mathrm{O}_{4}$, especially jacobsite forms wide range of solid solutions. Because the whole stability field of jacobsite 
solid solution and its paragenetic relations in the $\mathrm{Mn}_{3} \mathrm{O}_{4}-\mathrm{MnFe}_{2} \mathrm{O}_{4}-\mathrm{MnAl}_{2} \mathrm{O}_{4}$ and $\mathrm{Mn}_{3} \mathrm{O}_{4}-\mathrm{MnFe}_{2} \mathrm{O}_{4}$-" $\mathrm{Mn}_{2} \mathrm{TiO}_{4}$ " systems in the natural manganese deposits of Japan have already been reported by FUKUOKA and HIROWATARI (1980b), the relationship between the iron content in alabandite and the minerals in the system $\mathrm{Mn}_{3} \mathrm{O}_{4}-\mathrm{Fe}_{3} \mathrm{O}_{4}$ is considered here within the $\mathrm{Mn}_{3} \mathrm{O}_{4}-\mathrm{Fe}_{3} \mathrm{O}_{4}-\mathrm{MnS}-\mathrm{FeS}$ plane of the system Mn-Fe-S-O.

Jacobsite $\left(\mathrm{Mn}_{3} \mathrm{O}_{4}-\mathrm{Fe}_{3} \mathrm{O}_{4}\right.$ system)

The six samples of Hamayokogawa (5208, 5205), Nodatamagawa (L12-1,2), and Kaso $(28,29,2-B)$ were examined and the chemical analyses of jacobsite are shown in Appendix I-C.

The compositional relationship between alabandite and the associated jacobsite is given in Figure 5, plotted in the $\mathrm{Mn}_{3} \mathrm{O}_{4}-\mathrm{Fe}_{3} \mathrm{O}_{4}-\mathrm{MnS}-\mathrm{FeS}$ plane. Phase relations in the $\mathrm{Mn}-\mathrm{Fe}-\mathrm{S}-\mathrm{O}$ system are tentatively shown in Figure 6 in relation to other parageneses observed in nature.

Although the stoichiometric composition of jacobsite is $\mathrm{MnFe}_{2} \mathrm{O}_{4}$, natural jacobsite generally has the composition shifted a little toward the $\mathrm{Mn}_{3} \mathrm{O}_{4}$ side. The iron sulfide, which can occur associated with jacobsite of these compositions, is pyrite and the associated alabandite usually contains less than 2 mol. $\% \mathrm{FeS}$. Further, alabandite accompanied with hausmannite contains smaller amount of

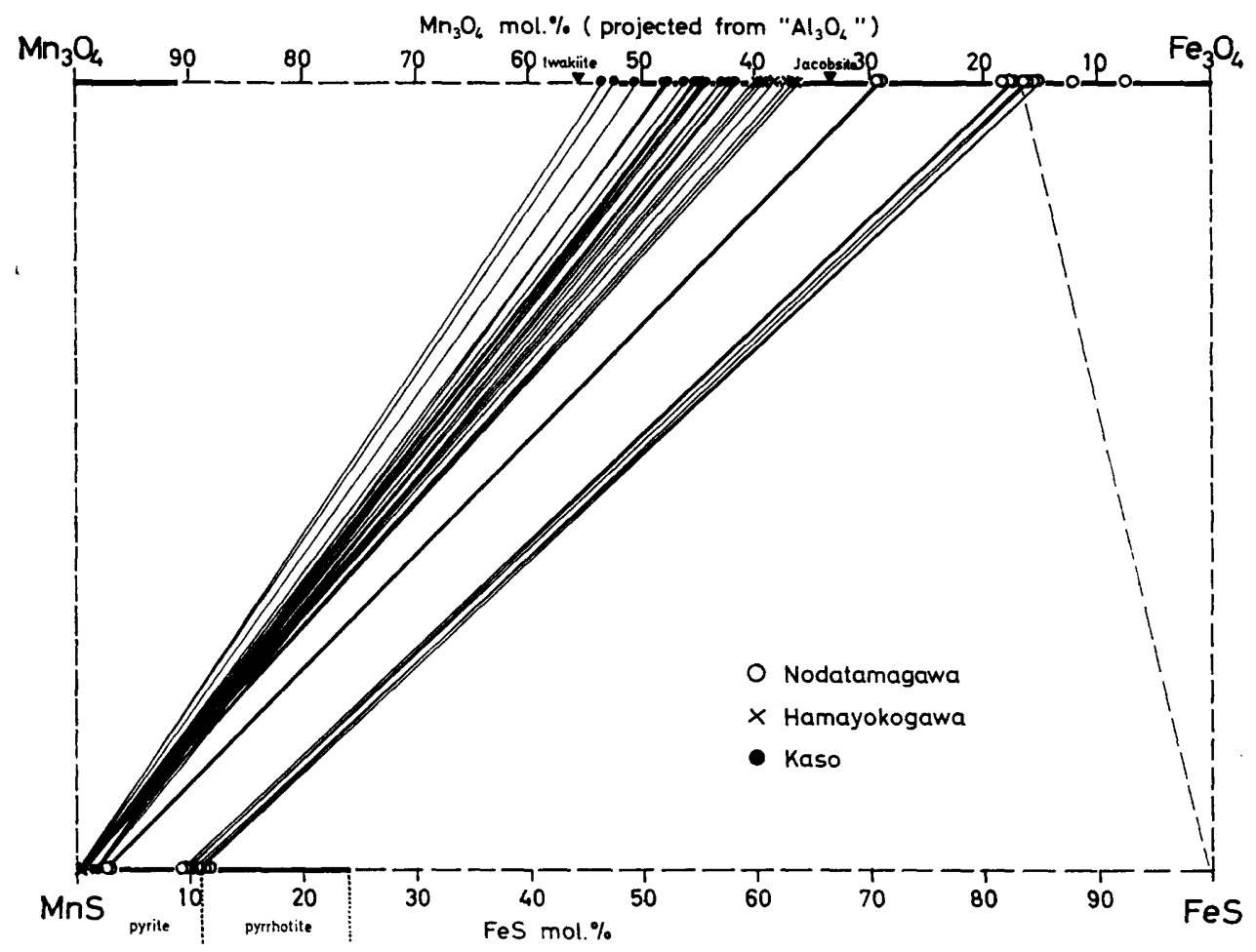

Fig. 5. Relation between iron content in jacobsite and that in alabandite on the $\mathrm{Mn}_{3} \mathrm{O}_{4}-\mathrm{Fe}_{3} \mathrm{O}_{4}-\mathrm{MnS}-\mathrm{FeS}$ plane of $\mathrm{Mn}-\mathrm{Fe}-\mathrm{S}-\mathrm{O}$ system. 
0

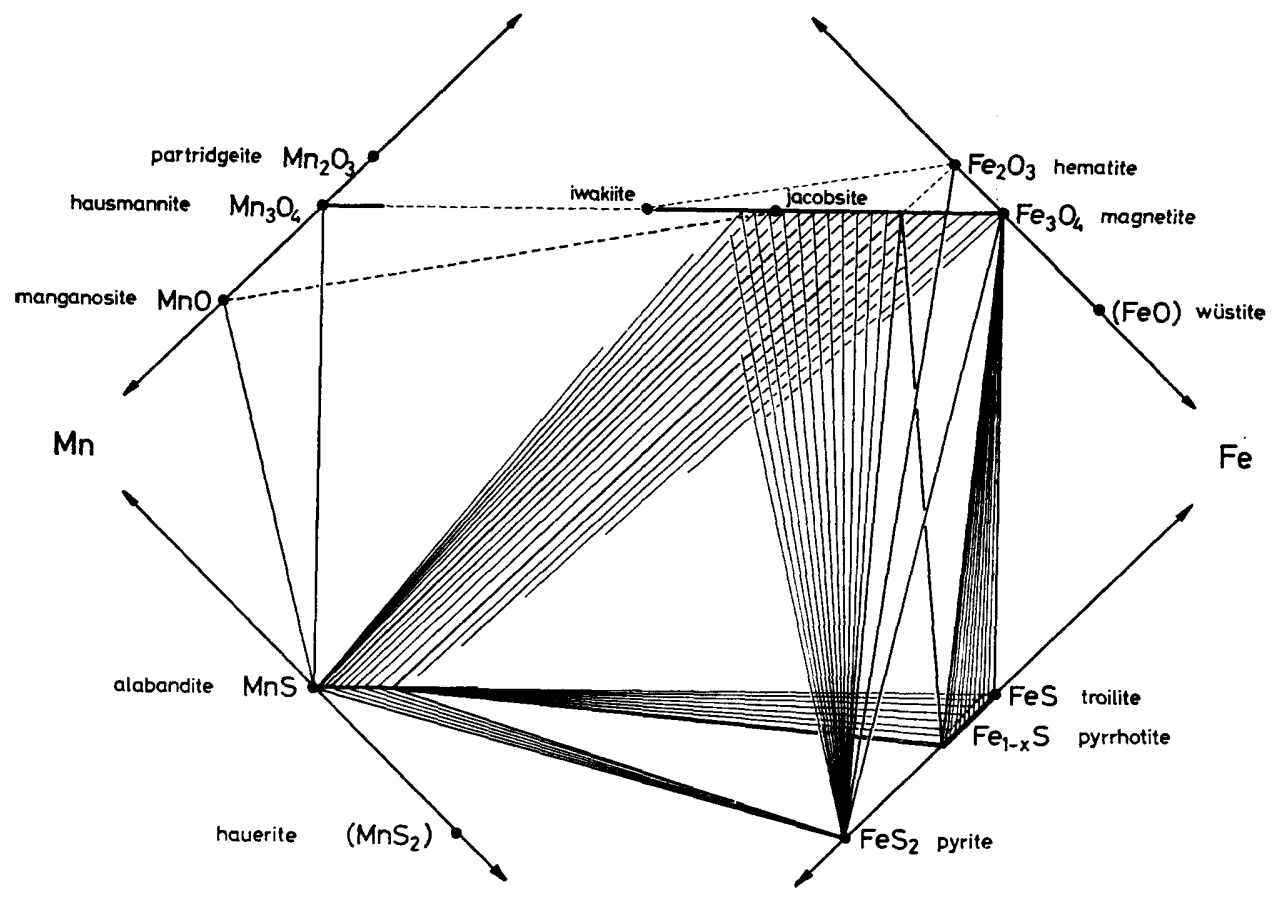

S

Fig. 6. Possible phase relations in the system $\mathrm{Mn}-\mathrm{Fe}-\mathrm{S}-\mathrm{O}$ for the natural manganese deposits.

FeS. This is compatible with the fact that the FeS content of alabandite in the manganosite and/or hausmannite ore is less than 1 mol.\% without exception as shown in Table 3.

But when alabandite is associated with jacobsite or Mn-bearing magnetite having iron-rich compositions, the $\mathrm{FeS}$ content increases in proportion to the amount of $\mathrm{Fe}_{3} \mathrm{O}_{4}$ in the oxide. In the four phase assemblage of pyrrhotite+ pyrite+alabandite+jacobsite observed in the sample of Nodatamagawa (L12-1,2), the iron content in alabandite and jacobsite is about $11 \mathrm{~mol} . \% \mathrm{FeS}$ and 83 mol.\% $\mathrm{Fe}_{3} \mathrm{O}_{4}$, respectively. Although no three phase assemblage, alabandite+ pyrrhotite+magnetite, was observed in this study, it could be explained that the more abundant iron is dissolved in alabandite.

From the results, it is inferred that the iron in the ore bodies has been preferentially seized into oxides to form jacobsite, and consequently alabandite was formed with low iron content under the stability conditions of the manganese oxides.

\section{Manganese silicates}

There are many kinds of manganese silicate minerals associated with 

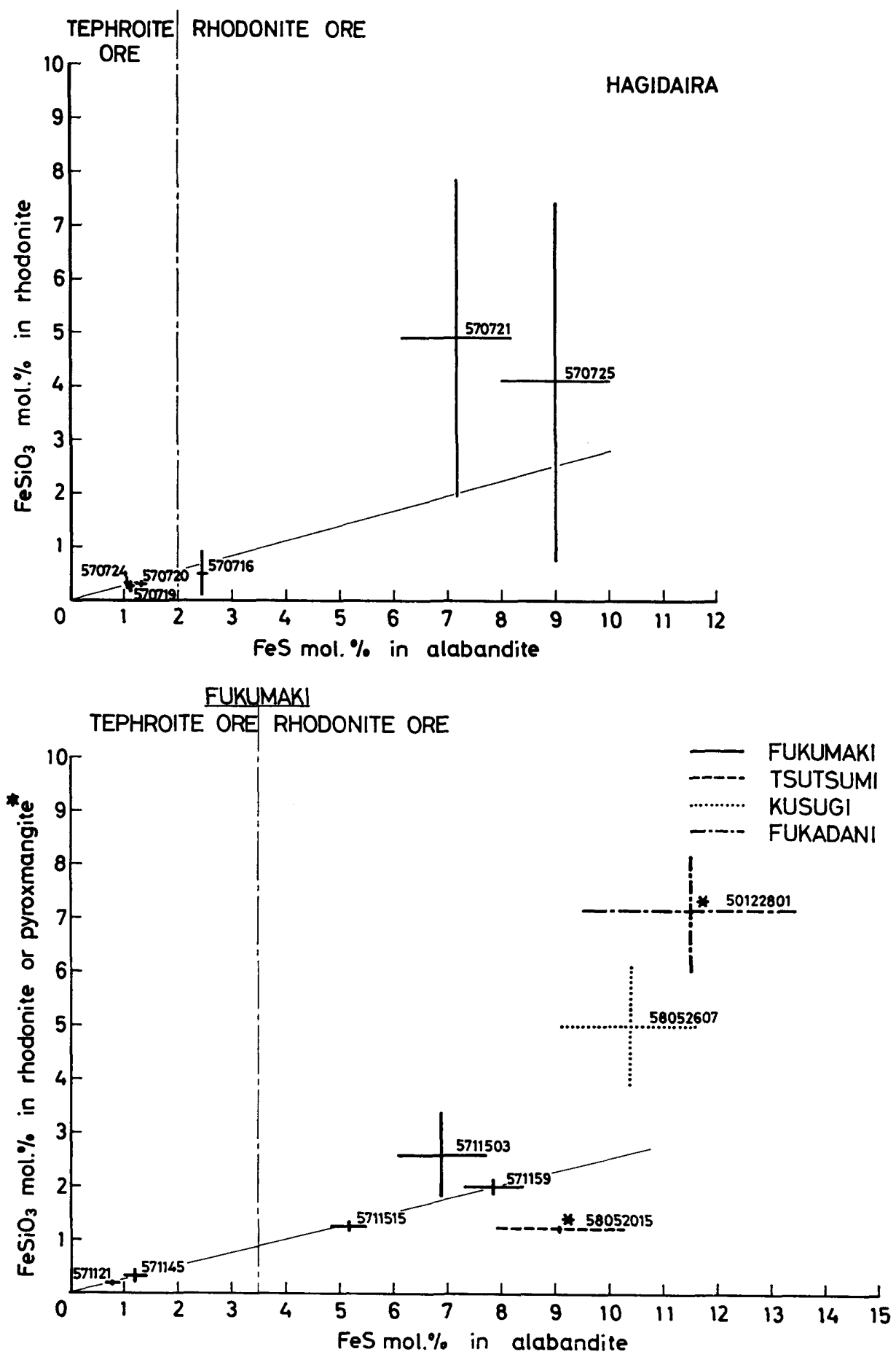

Fig. 7. Relation between iron content in rhodonite or pyroxmangite and that in alabandite.

a (upper): for Hagidaira mine,

b (lower): for Fukumaki, Tsutsumi, Kusugi, and Fukadani mines. 
alabandite, but the most abundant and common minerals are rhodonite (or pyroxmangite), tephroite, and Mn-humites (alleghanyite and sonolite). These minerals can be divided into two pairs of rhodonite and pyroxmangite, and tephroite and Mn-humites by the compositional relations to alabandite as shown in Table 3. Relationship between the iron content in alabandite and that in the coexisting silicate minerals is considered for each pair as follows.

The samples examined amount to thirty-one in all, that is, Hanawa (570733), Shōwa (570708, 570706, 570704, 570707, 570709), Hagidaira (570728, 570730, 570719, 570720, 570724, 570716, 570721, 570725), Fukadani (50122801), Fukumaki (5711516, 5700521, 571121, 571193, 571145, 5711109(c), 5711505, 571118, 571148,5711109 (a), 5711128(a), 5711515, 5711503, 571159), Kusugi (58052607), and Tsutsumi (58052015). The chemical analyses of rhodonite, pyroxmangite, tephroite, alleghanyite, and sonolite are shown in Appendix I-D, -E, -F, -G, and $-\mathrm{H}$, respectively.

\section{Rhodonite and pyroxmangite}

The relations between the $\mathrm{FeSiO}_{3}$ content in rhodonite and pyroxmangite and the FeS content in alabandite is shown in Figure 7 . The samples from Hagidaira and Fukumaki can be divided into two groups by the $\mathrm{FeS}$ content of alabandite, namely $2 \mathrm{~mol} . \%$ and $3.5 \mathrm{~mol} . \%$. The iron-rich alabandite occurs in the rhodonite ore, and the iron-poor alabandite in the tephroite ore. The samples of Tsutsumi, Kusugi, and Fukadani mines consist of the rhodonite or pyroxmangite ore. In each case, the $\mathrm{FeSiO}_{3}$ content in the pyroxenoids increases in proportion to the iron content in alabandite. But when $\mathrm{FeS}$ exceeds 6 or $7 \mathrm{~mol} . \%$, the $\mathrm{FeSiO}_{3}$ content increases very rapidly and the variation of the iron content in the pyroxenoids within the same sample also becomes larger. Because alabandite exsoluted an excess iron content as pyrrhotite. The difference between the iron content in rhodonite and pyroxmangite cannot be established clearly.

From these facts, it is pointed out that the iron content in the ores increases toward the rhodonite ore. Furthermore, the tendency becomes even greater as the amount of the iron sulfides increases when alabandite has higher FeS content (Table 3 ).

Tephroite and Mn-humites (alleghanyite and sonolite)

The relation between the iron content in tephroite and Mn-humites and that in alabandite is shown in Figure 8. The boundary values of $\mathrm{FeS}$ content in alabandite accompanied with rhodonite and tephroite ores in the Hagidaira and Fukumaki mines are the same as in Figure 7. The alabandite in the Showa and Hanawa mines is associated with rhodochrosite ore and that in the Tsutsumi mine is with pyroxmangite ore. The partition of iron between Mn-humites and alabandite leans slightly toward alabandite compared to that between tephroite and alabandite. However, it is considerably toward the silicates compared to that between pyroxenoids and alabandite. It is noteworthy that the relation given in Figure 8 shows a very clear linearity in comparison with the others.

Generally, the Mn-humites form solid solutions with wide range of iron content, as suggested from an example of low grade manganese ore from 
HAGIOAIRA

TEPHROITE RHODONITE ORE
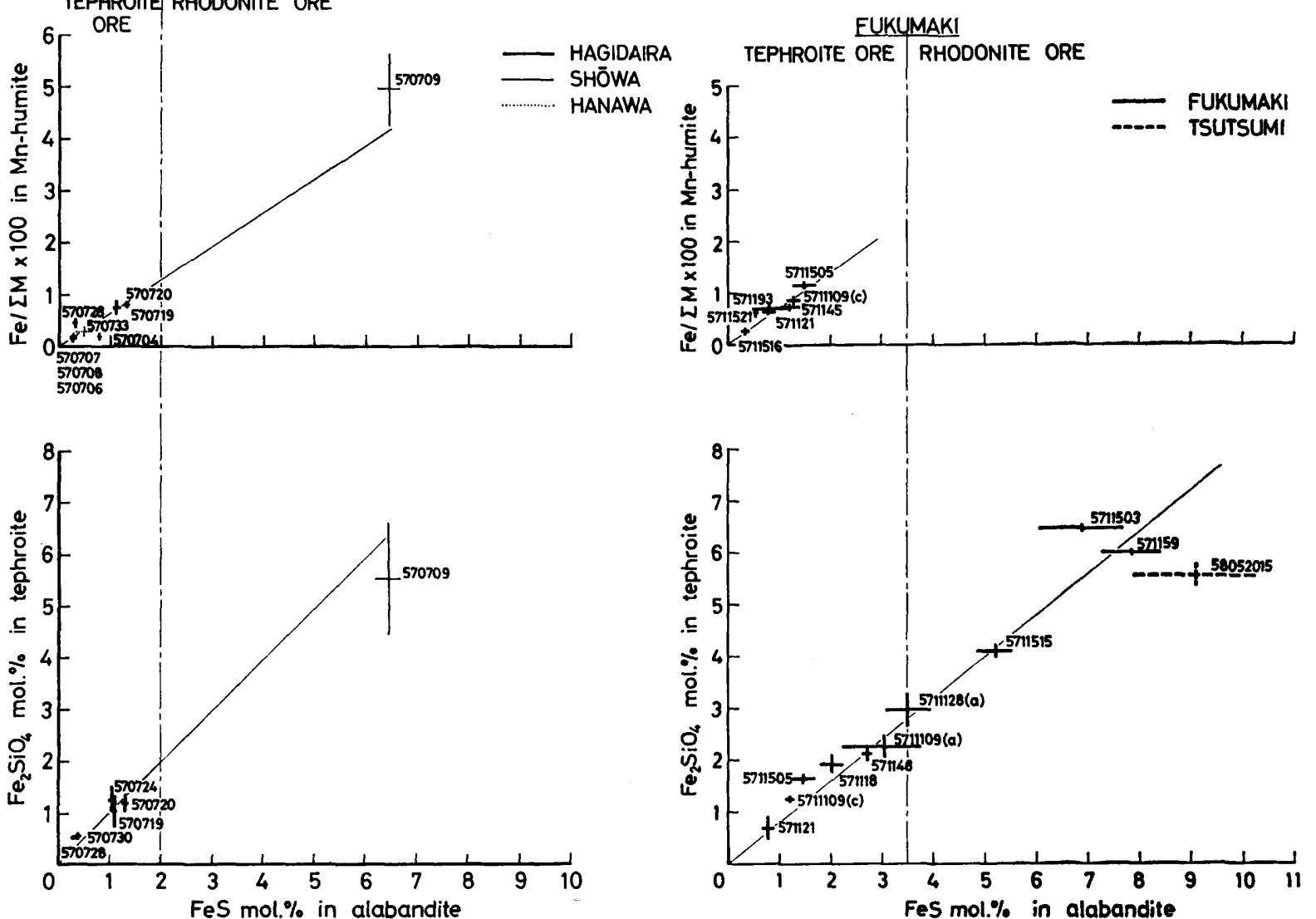

Fig. 8. Relation between iron content in tephroite or Mn-humites (alleghanyite and sonolite) and that in alabandite. a (left): for Hagidaira, Shōwa, and Hanawa mines,

b (right): for Fukumaki and Tsutsumi mines. 
Shōwa (570709) where the amount of iron in the Mn-humite is very high and is nearly equal to that in the tephroite. But the Mn-humites are usually associated with high grade manganese ores such as manganese oxides, rhodochrosite, and tephroite, and the iron content is usually low. This may be due to the lack of iron when Mn-humites were formed.

In these cases of tephroite and Mn-humites, the same tendency is recognized again as the iron increases toward the rhodonite end from the tephroite side. Even when the difference of partition of iron in the rhodonite-alabandite and tephroite-alabandite pairs is considered, the tendency is still observed judging from the results in Figure 7 and Figure 8.

The fact that alabandite and associated manganese silicates have close correlation with respect to at least iron content indicates that these minerals have been formed intimately and simultaneously. Moreover it is most probable that the iron content of alabandite is mostly controlled by the partition coefficients of iron in relation to the associated major manganese silicates.

\section{Manganese carbonates}

As the manganese carbonates are the most common minerals associated with alabandite, the chemical composition and paragenesis of these minerals were also considered.

\section{Rhodochrosite}

The samples examined amount to twenty-seven in all, they are, Inakuraishi (R.C.), Hanawa (570733), Shōwa (570708, 570706, 570704, 570707, 570709), Hijikuzu (621095), Hagidaira (570730, 570719, 570720, 570724, 570716, 570721, 570725), Fukadani (50122801), Fukumaki (5711516, 5711521, 571121, 571193, 571145,571119 (c), 5711505, 571118, 571148, 571159), and Tsutsumi (58052015).

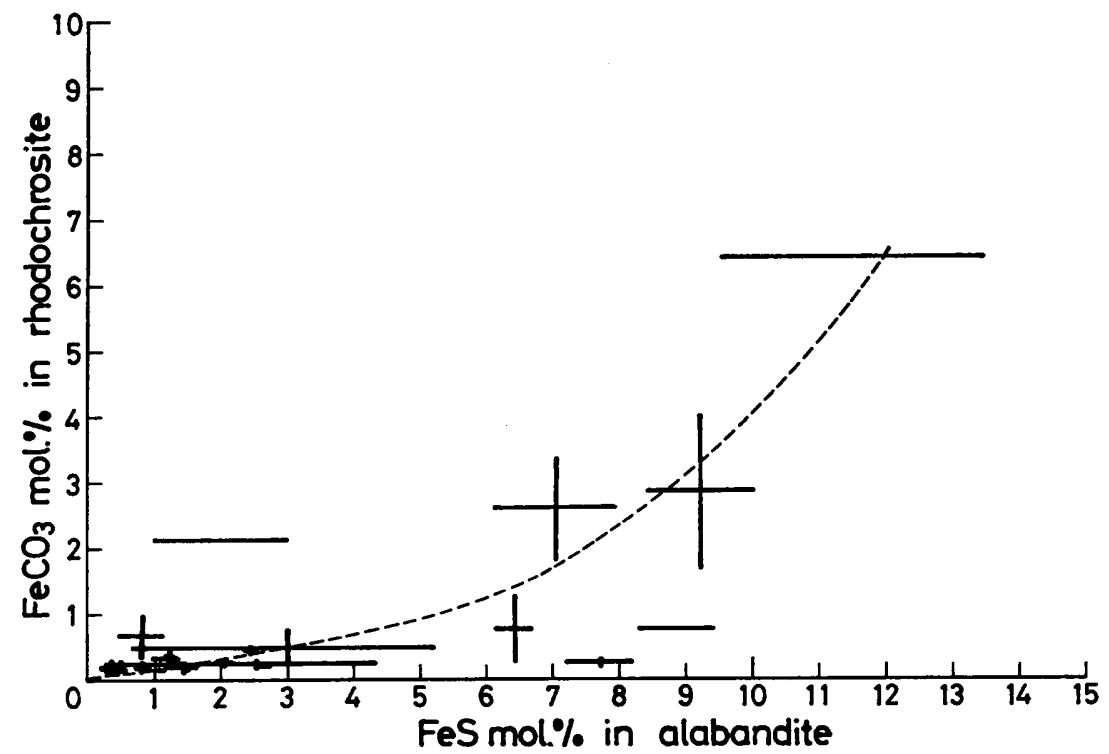

Fig. 9. Relation between iron content in rhodochrosite and that in alabandite. 
The chemical analyses of manganese carbonates are shown in Appendix I-I. Their composition mostly converges into the rhodochrosite end member.

The relation between the iron content in rhodochrosite and that in alabandite

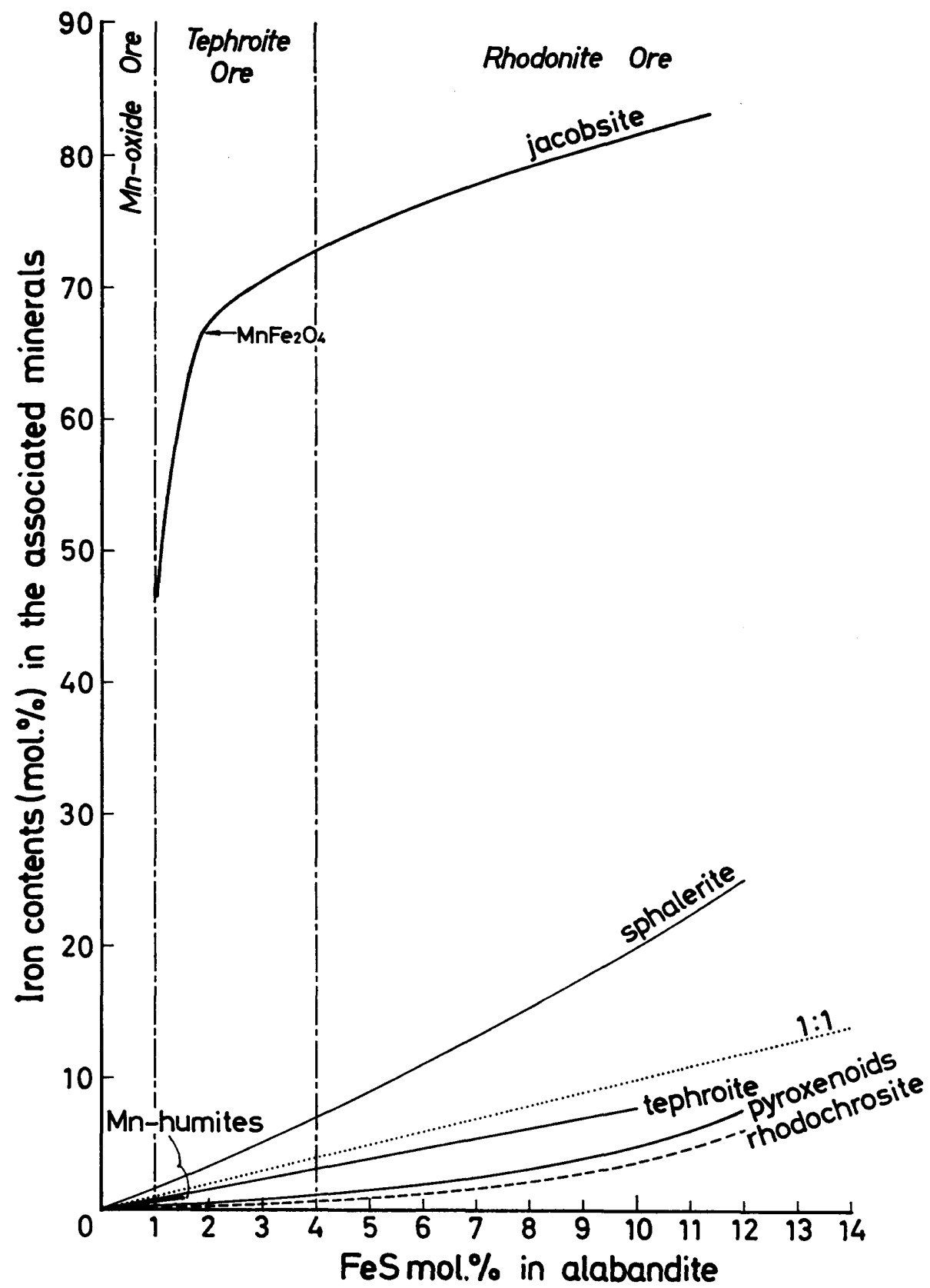

Fig. 10. Summary of the relations of iron content in alabandite versus that in sphalerite, jacobsite, pyroxenoids (rhodonite and pyroxmangite), tephroite, $\mathrm{Mn}$ humites (alleghanyite and sonolite), and rhodochrosite. 
is represented in Figure 9. The correlation is observed between the iron content in rhodochrosite and in alabandite although it is not as clear as in the case of manganese silicates. However, the $\mathrm{FeCO}_{3}$ content of rhodochrosite in the manganese carbonates ore is mostly less than $1 \mathrm{~mol} \%$, and it does not fluctuate as widely as the $\mathrm{FeS}$ content in the associated alabandite.

The carbonates, however, frequently show irregular variations in the modes of occurrence, paragenetic relations, and chemical composition. It probably is due to the fact that they are sensitive to the environment during retrogressive process. Hence the carbonate composition does not always reflect the formation environment where alabandite deposited.

\section{E. Summary}

The relationships between the iron content in alabandite and those in several associated minerals are summarized in Figure 10. Considering all the samples shown in Figure 3, the boundary value of the FeS content in alabandite between Mn-oxide and tephroite ores and that between tephroite and rhodonite ores are 1 and 4, respectively. The figure indicates the distribution ratios of the iron content in the associated minerals against alabandite. The ratio is conspicuous in the case of jacobsite and followed by sphalerite, tephroite, Mnhumites (alleghanyite and sonolite), pyroxenoids (rhodonite and pyroxmangite), and rhodochrosite in the descending order. As to jacobsite, it is indicated by synthetic studies of ONo et al. (1971) that the higher the content of manganese in the $\mathrm{Mn}_{3} \mathrm{O}_{4}-\mathrm{Fe}_{3} \mathrm{O}_{4}$ system, the higher the oxygen pressure is maintained under the formation environment. Then, the iron content in other minerals could also have been influenced by the oxygen pressures which controlled the ratio $\mathrm{Fe}^{2+}$ to $\mathrm{Fe}^{3+}$.

In the bedded-type deposits affected by thermal metamorphism, the $\mathrm{FeS}$ content in alabandite generally increases according to the associated minerals in the order of manganosite and/or hausmannite and rhodochrosite, tephroite, and pyroxenoids as shown in Table 3. Because these assemblages are regarded to have been formed as a product of skarnization reactions among manganese carbonates, quartz, and silicate minerals, it is probable that the $\mathrm{FeS}$ content in alabandite has increased from the center of ore bodies to the wall rocks side and the oxygen pressure decreased. The variation of the bulk iron content in an ore body could not be quantitatively determined, but it is considered that the peripheral part of the ore body is rich in iron as compared with the central part.

In the unmetamorphosed bedded-type deposits, the amount of alabandite and its iron content are relatively small and iron distribution in an ore body is estimated to be rather homogeneous.

In the vein-type deposits, rhodochrosite is the major manganese mineral associated with alabandite and the reaction between the solid phase and hydrothermal solutions predominates over that between the solid phases, thus the distribution relations of the iron content are generally obscure.

From these results, it is concluded that considerable amount of iron ac- 
companied with sulfur was surely introduced from the wall rocks into the ore body under thermal metamorphism.

\section{Genetic environment of alabandite}

Although the modes of occurrence, paragenetic relations, and chemical composition of alabandite and several associated minerals are described above, it is still difficult to discuss the problems related to the physicochemical conditions and processes by which alabandite has formed, because it is intimately connected with the ore geneses involving the whole manganese deposits and also because the available synthetic experimental results and the thermochemical data are restricted to a few manganese minerals and moreover the laboratory data on natural assemblages are insufficient to quantify the complicated phase relations in nature.

Here, the author intends to discuss the genetic environment of alabandite by using chemical reactions within the $\mathrm{Mn}-\mathrm{S}-\mathrm{C}-\mathrm{O}-\mathrm{Si}$ system. The temperature range of interest is presumed to be $200-600^{\circ} \mathrm{C}$ and the total pressure is 1 bar in almost all cases. In reactions with gas phases in the equilibrium state higher pressures occur, but as the discussion is in the order of magnitude, the effects based on the difference of the total pressures and the addition of the other elements are neglected.

The next six equations are accepted as the principal reactions:

$$
\begin{aligned}
& \mathrm{MnCO}_{3}+\mathrm{SiO}_{2}=\mathrm{MnSiO}_{3}+\mathrm{CO}_{2}(\mathrm{~g}) \\
& \mathrm{MnCO}_{3}+\mathrm{MnSiO}_{3}=\mathrm{Mn}_{2} \mathrm{SiO}_{4}+\mathrm{CO}_{2}(\mathrm{~g}) \\
& \mathrm{MnCO}_{3}=\mathrm{MnO} \mathrm{CO}_{2}(\mathrm{~g}) \\
& 6 \mathrm{MnCO}_{3}+\mathrm{O}_{2}(\mathrm{~g})=2 \mathrm{Mn}_{3} \mathrm{O}_{4}+6 \mathrm{CO}_{2}(\mathrm{~g}) \\
& \mathrm{C}+\mathrm{O}_{2}(\mathrm{~g})=\mathrm{CO}_{2}(\mathrm{~g}) \\
& 6 \mathrm{MnO}+\mathrm{O}_{2}(\mathrm{~g})=2 \mathrm{Mn}_{3} \mathrm{O}_{4} .
\end{aligned}
$$

Then the reactions involving alabandite are expressed as follows:

$\mathrm{MnS}+2 \mathrm{O}_{2}(\mathrm{~g})=\mathrm{MnSO}_{4}$

$2 \mathrm{MnS}+2 \mathrm{SiO}_{2}+\mathrm{O}_{2}(\mathrm{~g})=2 \mathrm{MnSiO}_{3}+\mathrm{S}_{2}(\mathrm{~g})$

$2 \mathrm{MnS}+\mathrm{SiO}_{2}+\mathrm{O}_{2}(\mathrm{~g})=\mathrm{Mn}_{2} \mathrm{SiO}_{4}+\mathrm{S}_{2}(\mathrm{~g})$

$2 \mathrm{MnS}+\mathrm{O}_{2}(\mathrm{~g})=2 \mathrm{MnO}+\mathrm{S}_{2}(\mathrm{~g})$

$6 \mathrm{MnS}+4 \mathrm{O}_{2}(\mathrm{~g})=2 \mathrm{Mn}_{3} \mathrm{O}_{4}+3 \mathrm{~S}_{2}(\mathrm{~g})$

$2 \mathrm{MnS}+2 \mathrm{CO}_{2}(\mathrm{~g})+\mathrm{O}_{2}(\mathrm{~g})=2 \mathrm{MnCO}_{3}+\mathrm{S}_{2}(\mathrm{~g})$.

In order to represent these reactions on a temperature- $\mathrm{fo}_{2}$ diagram, the value of $\mathrm{fco}_{2}$ from the equations (1) to (3) and that of $\mathrm{fS}_{2}$ from pyrrhotitepyrite equilibrium are used. These values are likely to be within the range which alabandite-bearing manganese deposits were formed in nature. The equilibrium constants determined experimentally by CANDIA et al. (1975) and HUEBNER (1969) are used for the equations (1), (2), and (3) (Figure 11). Compiled data by BARToN and ToulmiN (1979) are applied to the pyrrhotitepyrite reaction. FRENCH and EugSter (1965), HUEBNER and Sato (1970), and HollaNd (1965) are adopted for the equations (5), (6), and (7), respectively. 


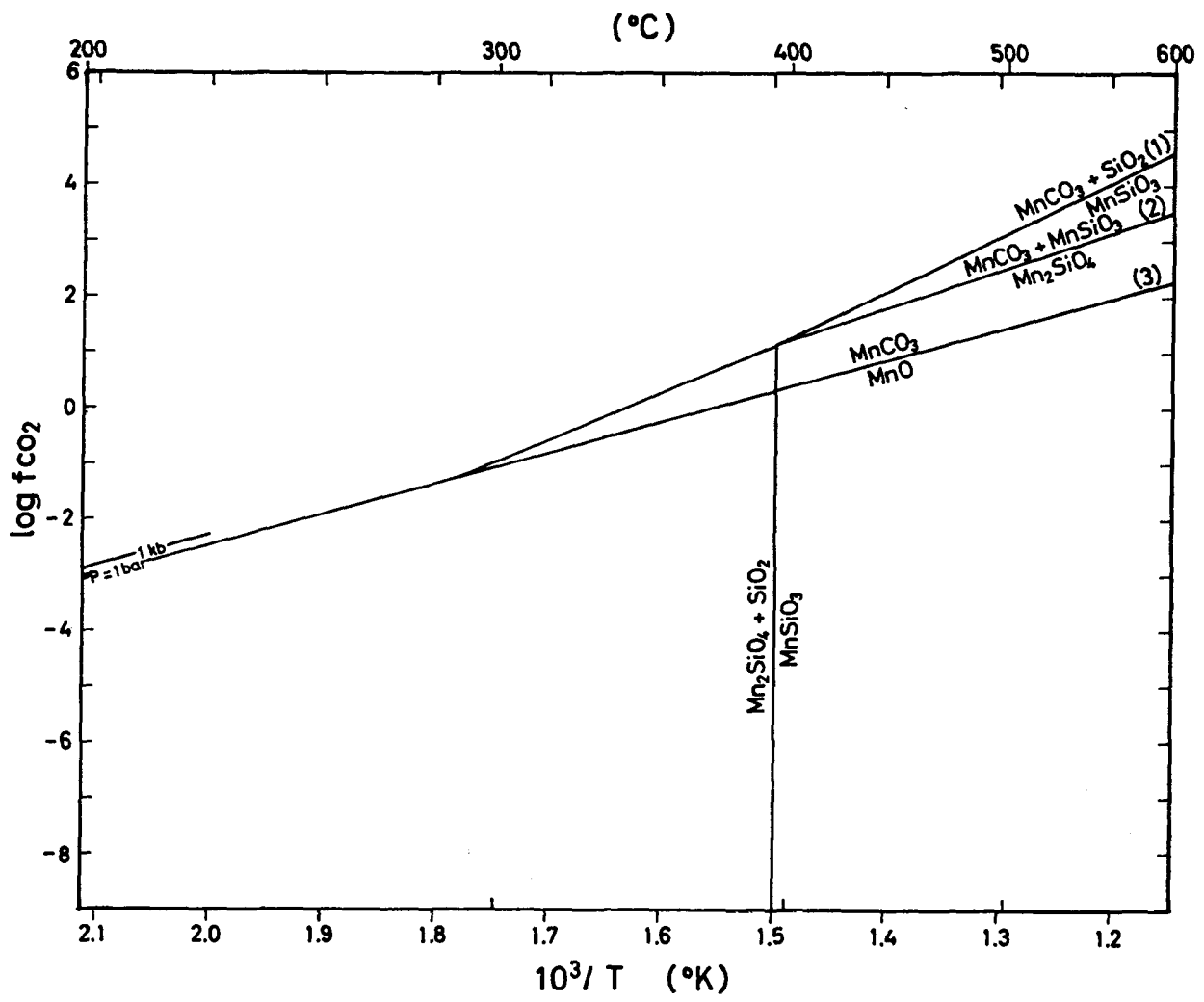

Fig. 11. Fugacity of $\mathrm{CO}_{2}$-temperature diagram for the reactions of (1) $\mathrm{MnCO}_{3}+$ $\mathrm{SiO}_{2}=\mathrm{MnSiO}_{3}+\mathrm{CO}_{2}$ (by CANDIA et al., 1975), (2) $\mathrm{MnCO}_{3}+\mathrm{MnSiO}_{3}=\mathrm{Mn}_{2} \mathrm{SiO}_{4}+\mathrm{CO}_{2}$ (by CANdia et al., 1975), and (3) $\mathrm{MnCO}_{3}=\mathrm{MnO}+\mathrm{CO}_{2}$ (by HUebNer, 1969).

Equilibrium constants for the other equations were calculated by using the thermochemical data presented by ROBIE et al. (1978).

The above equations and other several reactions of interest are plotted on a $\log \mathrm{fo}_{2}-1 / \mathrm{T}\left({ }^{\circ} \mathrm{K}\right)$ diagram as shown in Figure 12. In the figure, the upper boundary of alabandite stability field is controlled by the equation (7) and the lower limit is probably by equations (8) and/or (9). Other reactions involving alabandite are within this range. As alabandite stability coincides fundamentally with manganosite-hausmannite equilibrium (6) which is commonly found in nature, it is fully understood that alabandite should occur extensively in manganese deposits.

The modes of occurrence of alabandite are divided into three types as shown in Table 3. The difference of these occurrences will be considered from the relations given in Figure 12.

In the vein-type deposits, the alabandite stability is principally controlled by equations (1), (8), and (12). The $\mathrm{fs}_{2}$ is assumed to be slightly higher than that of the pyrrhotite-pyrite equilibrium, and the $\mathrm{fco}_{2}$ considerably higher than that of the equation (1). Therefore, the curves of equations (8) and (12), shown in Figure 12, are depicted to the higher side of $\mathrm{fo}_{2}$. Moreover, the 


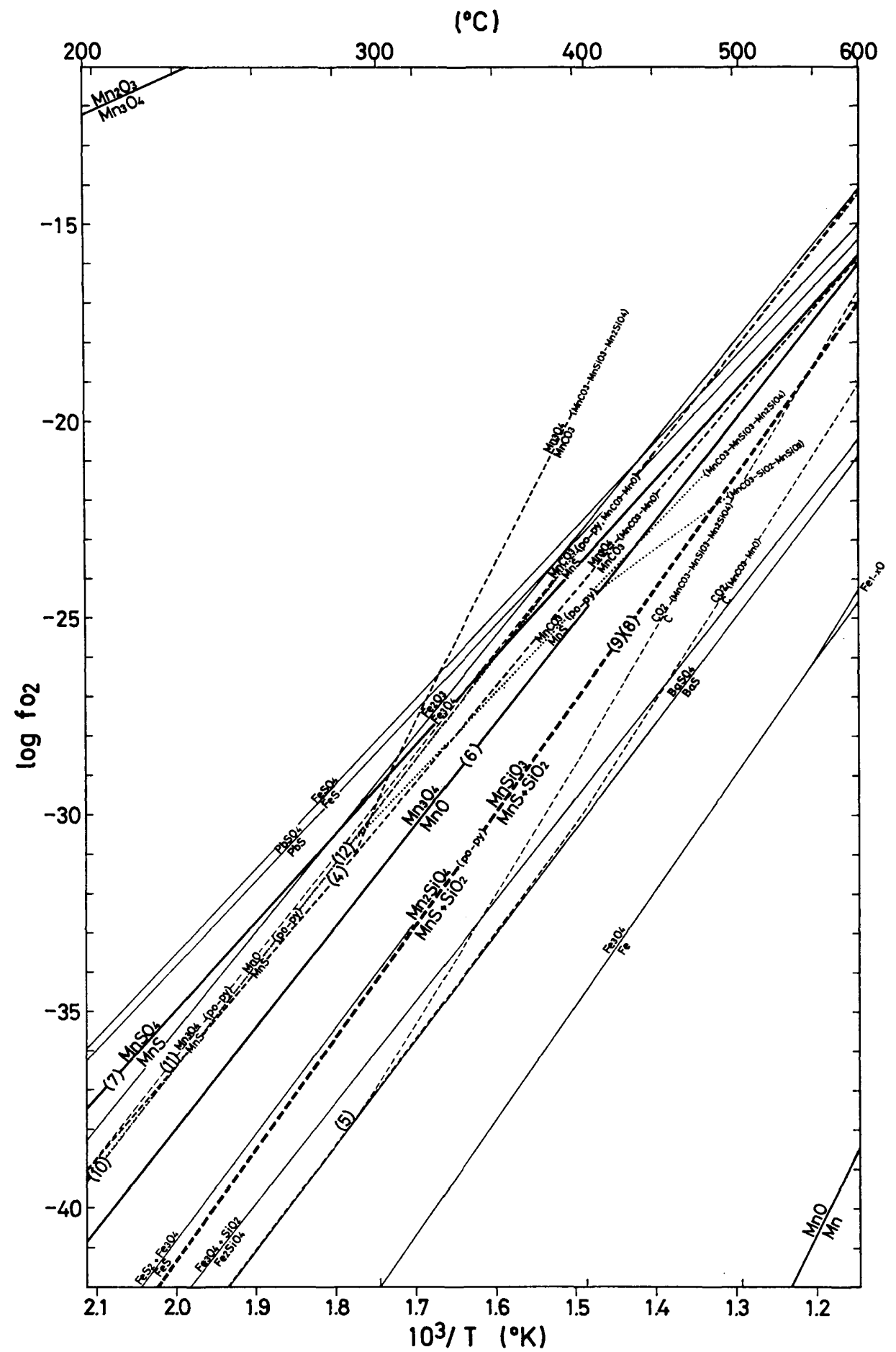

Fig. 12. Fugacity of $\mathrm{O}_{2}$-temperature diagram for the available reactions of $\mathrm{Mn}-\mathrm{S}-\mathrm{O}-\mathrm{C}-\mathrm{Si}$ system. 
equation (12) is inferred to shift toward lower side of $\mathrm{fo}_{2}$. According to the experiments on fluid inclusions and measurements of $\mathrm{FeS}$ content in sphalerite and associated minerals (e.g., ENJOJI and TAKENOUCHI, 1976), it seems that the $\mathrm{fo}_{2}$ generally enters the field between the reactions (7) and (8) or (9) in the range $200-300^{\circ} \mathrm{C}$. But in the more strict sense, the ore solution chemistry including the parameter of $\mathrm{pH}$ and so on should be considered because the solution played an important role in this case.

In the unmetamorphosed bedded-type deposits, if the $\mathrm{fco}_{2}$ is controlled by the equations (2) and (3) and if hausmannite is present, the $\mathrm{fo}_{2}$ will be near the upper boundary of the equation (4). From the equation (12), the increase of $\mathrm{fco}_{2}$ is accompanied with the decrease of $\mathrm{fo}_{2}$ at constant $\mathrm{fs}_{2}$, and if the $\mathrm{fs}_{2}$ is equivalent to that of the pyrrhotite-pyrite equilibrium, the rhodochrosite+ alabandite assemblage is stable in the field between equations (6) and (7). Because these deposits are generally composed mainly of rhodochrosite, the minor alabandite is most probably formed under the conditions of the equation (12).

In the metamorphosed bedded-type deposits, the predominant reactions in the manganosite and/or hausmannite-rhodochrosite ores can be regarded as the same as in the case of unmetamorphosed deposits, although the ranges of the formation temperatures are different. But in the tephroite and the rhodonite and/or pyroxmangite ores, the $\mathrm{fco}_{2}$ is controlled by equations (1) and (2), and equations (8) and (9) predominate over the equation (12). The variations of the $\mathrm{FeS}$ content in alabandite cannot be interpreted by reactions given in Figure 12, because the small changes of the $\mathrm{fs}_{2}$ should cause sensitive fluctuation of $\mathrm{FeS}$ content in alabandite and such sensitive changes cannot be handled in this discussion. But if the $\mathrm{fs}_{2}$ varies in proportion to the $\mathrm{fo}_{2}$ of equations $(8)-(11)$, it is very likely that the $f_{s_{2}}$ decreases together with the $f_{2}$, as the $\mathrm{fco}_{2}$ increases generally from the value fixed by the equation (3) to the value by the equation (1). From the results, it is concluded that alabandite exhibits high ability to seize the $\mathrm{FeS}$ in the low grade manganese ore.

It is also concluded that two factors played important roles in the formation of alabandite-bearing ores in the manganese deposits: 1) the supply of iron to the peripheral part of a ore body, and 2) the difference in distribution ratios of the iron content between tephroite/alabandite and pyroxenoid/alabandite.

\section{Concluding remarks}

The results of the present study show that the paragenetic relations, chemical composition, and genetic environment of alabandite-bearing ores in the manganese deposits of Japan can be summarized as follows:

1) The paragenetic relations and chemical composition of alabandite are largely divided into three types by the differences in their modes of occurrence.

(i) Tertiary vein-type deposits Alabandite locally occurs as coarse grains, whose composition is generally heterogeneous with $\mathrm{FeS}$ content of 0.6 to 5.8 mol.\%. No exsolution products are found in the minerals. The associated minerals consist mainly of rhodochrosite, pyrite, and quartz, and partly rhodonite. 
(ii) Paleozoic to Mesozoic, unmetamorphosed bedded-type deposits Small amount of alabandite occurs dispersed in the deposits. It is fine-grained, composition is comparatively homogeneous within one grain, and the range of $\mathrm{FeS}$ is 0.2 to $6.6 \mathrm{~mol} . \%$. There is no exsolved mineral in alabandite. The associated minerals are mainly rhodochrosite accompanied with many kinds of manganese oxides and silicates, but very rarely with iron sulfides.

(iii) Paleozoic to Mesozoic, thermally metamorphosed bedded-type deposits Alabandite is abundant and widespread as medium to coarse grains in the deposits. Composition is quite homogeneous within one grain. The FeS content of alabandite ranges from 0.3 to $13.5 \mathrm{~mol} \%$. It frequently contains pyrrhotite as exsolution products. The associated minerals consist of tephroite, rhodonite, and many kinds of the other manganese silicates, oxides, and carbonates. Abundant pyrrhotite and pyrite also coexist with alabandite.

2) In the above bedded-type deposits, there is a close correlation between the FeS content of alabandite and the kinds of the associated minerals. Namely, the FeS content in alabandite associated with hausmannite (including manganosite and jacobsite) is less than 2 mol.\%, tephroite less than 4 mol. $\%$, and rhodonite (including pyroxmangite) less than $13.5 \mathrm{~mol} \%$. In the highly metamorphosed deposits, FeS content of alabandite generally increases from the central to the peripheral parts.

3) As to the localization of alabandite occurrence by deposit types and also variation of the $\mathrm{FeS}$ content in alabandite, it is explained not only by the differences in the distribution ratios of the iron between alabandite and the associated manganese oxides (particularly, jacobsite) and silicates (especially, tephroite, alleghanyite, sonolite, rhodonite, and pyroxmangite) but also by the introduction of iron accompanied with sulfur into the ore bodies during thermal metamorphism.

4) The stability field of alabandite can be calculated by using the selected principal reactions. It coincides approximately with the stability field of manganosite-hausmannite assemblage within the temperature range of deposit formation. This implies that alabandite occurs under wide range of physicochemical conditions.

5) The FeS content in all alabandites analysed in this study ranges from 0.2 to $13.5 \mathrm{~mol} . \%$. Formation temperature can be calculated from the maximum $\mathrm{FeS}$ content to be about $350^{\circ} \mathrm{C}$ by using the alabandite geothermometer of SUGAKI and KITAKAZE (1972). But this indicates the temperature when the exsolution was completed during the later cooling period. The reaction rate of alabandite is considered to be relatively rapid. Therefore, the FeS content in alabandite in nature do not exceeded $\mathbf{1 3 . 5} \mathrm{mol} \%$ to a large degree.

\section{Acknowledgements}

The writer is much indebted to Professor Fumitoshi Hirowatari, Kyushu University, for his continuiting guidance and encouragement, and furthermore for permitting him to use many samples. He expresses his sincere gratitude 
to Dr. Nobutaka Shimada, Kyushu University, for helpful suggestions and critical reading of the manuscript. $\mathrm{He}$ is also grateful to Professor Haruo SHIRozU and Dr. Yoshikazu AoKI, Kyushu University, for informative discussions and valuable advice.

He would like to thank to Dr. Hiroharu MAtsuEdA, Akita University, for providing the valuable samples from the Nodatamagawa and Yamada mines. Thanks are also due to Mr. Yoshinobu MотомURA, Kyushu University, for many helpful suggestions during the course of this work. Mrs. Hidemi AKamine, Kyushu University, kindly assisted the author in microprobe work.

\section{References cited}

Barton, P. B., Jr. and Skinner, B. J. (1979) : Sulfide mineral stabilities. In Barnes, H. L. 2nd ed., Geochemistry of hydrothermal ore deposits, Wiley-Interscience, New York, 278-403.

Biltz, W. and WiechmanN, F. (1936): Zum System Mangan/Schwefel: Abbau und Synthese des Hauerits $\left(\mathrm{MnS}_{2}\right)$. Z. anorg. u. allg. Chem., 228, 268-274.

Candia, M. A. F., Peters, Tj. and Valarelli, J. V. (1975) : The experimental investigation of the reactions $\mathrm{MnCO}_{3}+\mathrm{SiO}_{2}=\mathrm{MnSiO}_{3}+\mathrm{CO}_{2}$ and $\mathrm{MnSiO}_{3}+\mathrm{MnCO}_{3}=$ $\mathrm{Mn}_{2} \mathrm{SiO}_{4}+\mathrm{CO}_{2}$ in $\mathrm{CO}_{2} / \mathrm{H}_{2} \mathrm{O}$ gasmixtures at a total pressure of 500 bars. Contrib. Mineral. Petrol., 52, 261-266.

Enjoji, M. and Takenouchi, S. (1976) : Present and future researches of fluid inclusions from vein-type deposits (in Japanese with English abstract). Mining Geol., Special Issue (7), 85-100.

French, B. M. and Eugster, H. P. (1965) : Experimental control of oxygen fugacities by graphite-gas equilibrium. J. Geophys. Res., 70, 1529-1539.

Fukuoka, M. and Hirowatari, F. (1980a): On minerals in the system Ni-Co-As-S from the bedded manganese ore deposits in the eastern part of Yamaguchi Prefecture: on the chemical compositions of gersdorffite-cobaltite solid solution (in Japanese with English abstract). Sci. Rept., Dept. Geol., Kyushu Univ., 13, (2), 239-249.

and (1980b) : Chemical compositions of jacobsites from the bedded manganese ore deposits (in Japanese with English abstract). Jour. Mineral. Soc. Japan, 14, Special Issue (3), 39-53.

and - (1981): Manganese content of sphalerite from the manganese deposits in Japan (in Japanese with English abstract). Sci. Rept., Dept. Geol., Kyushu Univ., 14, (1), 1-12.

Hansen, M. and ANDERKo, K. (1958) : Constitution of binary alloys, 1305 p, McGrawHill, New York.

HARADA, Z. (1954a) : Alabandite from the Inakuraisi mine, Siribesi Province, Hokkaido (in Japanese). Hoku-chi-yoho, 26, 24.

- (1954b) : Alabandite from the Tamamori mine, Siribesi Province, Hokkaido (in Japanese). Hoku-chi-yoho, 26, 24.

(1954c): On twin crystals of alabandite from the Inakuraisi mine, Siribesi Province, Hokkaido (in Japanese). Jour. Mineral. Soc. Japan, 1, (6), 433-434.

Hatae, N., Shirozu, H. and Momor, H. (1965): Manganese deposits in Amami-oshima district (in Japanese). Domestic Iron Resource Survey, MITI, (3), 224-236.

HatToRI, T. and Harada, H. (1969) : On the manganese silicate deposits of Furumiya mine in Ehime Prefecture-Report of the manganese silicate deposits in Japan (2)-(in Japanese with English abstract). Bull. Geol. Surv. Japan, 11, (7), $443-450$.

Hayashi, S. and Igarashi, T. (1962): Report on the radiometric survey in Seta-gun, 
Gumma Prefecture (in Japanese with English abstract). Bull. Geol. Surv. Japan, 13, (7), 573-582.

HewetT, D. F. and Rove, O. N. (1930): Occurrence and relations of alabandite. Econ. Geol., 25, 36-56.

HirokaWA, O. (Chief ed.) (1978): Geological map of Japan, 1:1,000,000 (2nd edition), Geol. Surv. Japan.

HirowataRI, F. (1961): Minerals and their paragenetic relations of the manganese deposits of Fukumaki mine, Yamaguchi Prefecture (in Japanese with English abstract). Bull. Geol. Surv. Japan, 12, (8), 565-572.

(1964) : On some manganese garnets from the manganese ore deposits of Japan (in Japanese with English abstract). Sci. Rept., Dept. Geol., Kyushu Univ., 7, (1), 113-119.

and TAKEDA, H. (1962a): On the manganese ore deposits in the Watarase river district, Gumma Prefecture-Report of the manganese silicate deposits in Japan (4) - (in Japanese with English abstract). Bull. Geol. Surv. Japan, 13, (5), 437-452.

and - (1962b): On the manganese ore deposits in the Kaso, Hikoma and Hishimura districts, Tochigi Prefecture-Report of the manganese silicate deposits in Japan (5) - (in Japanese with English abstract). Bull. Geol. Surv. Japan, 13, (8), 683-708.

Holland, H. D. (1965) : Some applications of thermochemical data to problems of ore deposits II. Mineral assemblages and the compositions of ore-forming fluids. Econ. Geol., 60, 1101-1166.

HUEBNER, J. S. (1969) : Stability relations of rhodochrosite in the system manganesecarbon-oxygen. Am. Mineral., 54, 457-481.

— and SATo, M. (1970): The oxygen fugacity-temperature relationships of manganese oxide and nickel oxide buffers. Am. Mineral., 55, 934-952.

IshIDA, H. (1976): Phase equilibrium study in the Mn-Fe-S system (in Japanese with English abstract). Unpub. M. Eng. thesis, Yamaguchi Univ.

- Sugaki, A. Shima, H. and Kitakaze, A. (1977): Phase equilibrium study in the Mn-Fe-S system (II) (abst.) (in Japanese). Joint Symposium, Niigata, C25.

Ito, T. and SAKURAI, K. (1947): Wada's minerals of Japan (3rd edition) (in Japanese), Mineral. Inst., Univ. Tokyo, Tokyo.

KAto, A. and Matsubara, S. (1980): Manganese borate minerals from Japan (in Japanese with English abstract). Jour. Mineral. Soc. Japan, 14, Special Issue (3), 86-97.

, Nakama, T. and Matsumoto, M. (1965): Manganese deposits in Aso and Kamitsuga districts (I) (in Japanese). Domestic Iron Resource Survey, MITI, (3), 146-154.

LEE, D. E. (1955) : Mineralogy of some Japanese manganese ores, 64 p, Stanford Univ., California.

Matsubara, S. and KAto, A. (1977): Unknown Ba-V-silicates from Mogurazawa mine in Kiryu City (abst.) (in Japanese). Annual Meet. Mineral. Soc. Japan, Tokyo, A01.

Mehmed, F. and Haraldsen, H. (1938): Das magnetische Verhalten der allotropen Modifikationen des Mangan (II)-Sulfids. Z. anorg. u. allg. Chem., 235, $193 œ 200$.

Miyamoto, H., Otsu, H. and Kawano, T. (1962): On the manganese silicates ore deposits in Taguchi district, Aichi Prefecture-Report of the manganese silicate deposits in Japan (3) - (in Japanese with English abstract). Bull. Geol. Surv. Japan, 13, (5), 424-436.

- C, TAKase, H. and Maruyama, S. (1954): Report on manganese deposits at Kanuma district, Tochigi Prefecture (in Japanese with English abstract). Bull. Geol. Surv. Japain, 5, (4) , 163-182.

NAMBU, M. (1965): Report of minerals from Iwate Prefecture (in Japanese), 252 p, 
Iwate Prefecture.

and TANIDA, K. (1964): Oxidation of the manganese ore deposits of Taki mine, Iwate Prefecture-With special reference to the formation of amorphous manganese dioxide mineral-(in Japanese with English abstract). Jour. Japan. Assoc. Mineral. Petrol. Econ. Geol., 51, (6), 223-232.

- - Kitamura, T. and Kumagai, S. (1976): Constituent minerals in the manganese ore deposits of Hijikuzu mine, Iwate Prefecture (abst.) (in Japanese). Joint Symposium, Kagoshima, B46.

- - OIKAwA, S., KumagaI, S. and Nasukawa, S. (1973): Manganese deposits in the Kitakami mountains $I I$ (in Japanese), $85 \mathrm{p}$, Iwate Prefecture.

ONo, K., Ueda, T., Ozaki, T., Ueda, Y., Yamaguchi, A. and MoriYama, J. (1971) : Thermodynamic study of the iron-manganese-oxygen system (in Japanese with English abstract). Nippon Kinzoku Gakkaishi, 35, (8), 757-763.

Robie, R. A., Hemingway, B. S. and Fisher, J. R. (1978) : Thermodynamic properties of minerals and related substances at $298.15 \mathrm{~K}$ and 1 bar $\left(10^{5}\right.$ pascals $)$ pressure and at higher temperatures, 456 p, U.S. Geol. Survey Bull., 1452.

Saito, M., Bamba, T., SaWa, T., Narita, E., Igarashi, T., Yamada, K. and Satoh, H. (1967): Metallic and non-metallic mineral deposits of Hokkaido, Japan (in Japanese with English abstract), 575 p, Geol. Surv. Japan.

SAKUrar, K. (1956): Localities of sphalerite showing crystal forms (in Japanese). Jour. Mineral. Soc. Japan, 2, 385.

SATo, A., FukUdA, K. and WADA, T. (1957): On the manganese deposits and its prospecting of Nodatamagawa mine, Iwate Prefecture (1), (2) (in Japanese with English abstract). Mining Geol., 7, (23), (24), 13-21, 98-103.

SCHNAASE, H. (1933) : Kristallstruktur der Manganosulfide und ihrer Mischkristalle mit Zinksulfid und Cadmiumsulfid. Z. physik. Chem. Abt., 20, 89-117.

ScOTr, S. D. and BARNES, H. L. (1971): Sphalerite geothermometry and geobarometry. Econ. Geol., 66, 653-669.

Shinoda, M., Sakai, T., Koono, J. and KIKUChI, H. (1974) : Geology of the OoeInakuraishi mine, with special reference to the vein system (in Japanese with English abstract). Mining Geol., 24, (2), 119-128.

Shibata, Z. (1928): The equilibrium diagram of the iron sulphide-manganese sulphide system. Tech. Rep. Tohoku Imp. Univ., 6, 279-289.

SHIRozU, H. (1949): On the manganese deposits of the Ioi mine, Shiga Prefecture, with special reference to hausmannite (in Japanese with English abstract). Jour. Geol. Soc. Japan, 55, (646), 77-83.

Skinner, B. J. and Luce, F. D. (1971) : Solid solutions of the type (Ca, Mg, Mn, Fe)$\mathrm{S}$ and their use as geothermometers for the enstatite chondrites. Am. Mineral., 56, 1269-1296.

Sugaki, A. and Kitakaze, A. (1972): Chemical composition of synthetic alabandite solid solution and its phase relations in the system Fe-Mn-S. Proc. 6th Int. Conf. X-ray Opt. Microanl., 755-760.

SuZAki, Y., Urashima, Y. and Hayakawa, A. (1969): On the ore of the Yūbaridake manganese mine, Hokkaido (in Japanese with English abstract). Mining Geol., 19, (96), 147-158.

Tozuka, Y. and Kobayashi, S. (1964): Manganese deposits in Ashio district (in Japanese). Domestic Iron Resource Survey, MITI, (2), 190-195.

Watanabe, M. (1939): The pseudomorph of barite and the mode of occurrence of alabandite in silver and manganese ores from Mori mine (in Japanese). Jour. Japan. Assoc. Mineral. Petrol. Econ. Geol., 22, 136-147.

WatANABE, T. (1959): The minerals of the Noda-Tamagawa mine, Iwate Prefecture, Japan I. Notes on geology and parageneses of minerals. Mineral. Jour., 2, (6), 408-421. and Kimura, M. (1954): The mode of occurrence and paragenesis of alabandite 
(abst.) (in Japanese). Mining Geol., 4, 46.

, YUI, S. and KATo, A. (1970) : Bedded manganese deposits in Japan, a review. In TATsUmI, T. ed., Volcanism and ore genesis, Univ. Tokyo, Tokyo, 119-142.

Wyckoff, R. W. G. (1921): Art. XVII.-The structure of alabandite (MnS). Am. Jour. Sci., Fifth Series, II, 239-249.

YASUDA, M. (1965) : Manganese deposits in Ōidani district (in Japanese). Domestic Iron Resource Survey, MITI, (3), 203-205.

Yoshie, H. and Hirowatari, F. (1978): The modes of occurrence and ore minerals in the manganese deposits of Hamayokogawa mine (abst.) (in Japanese). Joint Symposium, Hiroshima, B18.

Yoshimura, T. (1937) : Alabandite and rhodochrosite from Hokkaido (abst.) (in Japanese). Jour. Geol. Soc. Japan, 44, 559-560.

(1967) : Supplement to "Manganese ore deposits of Japan" Part I Manganese mineralization, minerals and ores (in Japanese with English abstract). Sci. Rept., Dept. Geol., Kyushu Univ., 9, Special Issue (1), 1-485.

(1969) : Supplement to "Manganese ore deposits of Japan" Part II Manganese mines of Japan (in Japanese with English abstract). Sci. Rept., Dept. Geol., Kyushu Univ., 9, Special Issue (2), 487-1004.

and Momor, H. (1961): Dannemorite from Zomeki, Yamaguchi Prefecture, Japan (in Japanese with English abștract). Sci. Rept., Dept. Geol., Kyushu Univ., 5, (3), 99-110.

and- (1964): Withamite from the Yamanaka mine, Hyogo Prefecture (in Japanese with English abstract). Sci. Rept., Dept. Geol., Kyushu Univ., 6, (3), 201-206.

and Yoshinaga, M. (1959): Helvite from Yagisawa mine, Nagano Prefecture (in Japanese). Jour. Mineral. Soc. Japan, 4, $(1,2)$ 34-41. 
Appendix I. Electron microprobe data.

\begin{tabular}{|c|c|c|c|c|c|}
\hline \multirow[b]{2}{*}{ Inakuraishi } & \multicolumn{4}{|c|}{ wt. 8} & \multirow[b]{2}{*}{ Fes mol. 8} \\
\hline & $\overline{\mathbf{s}}$ & $\overline{M n}$ & $\mathrm{Fe}$ & Tota1 & \\
\hline R.C. $-A-1-1$ & 36.91 & 59.41 & 2.80 & 99.12 & 4.43 \\
\hline$-A-1-2$ & 37.25 & 59.99 & 3.37 & 100.61 & $\begin{array}{l}4.253 \\
5.23\end{array}$ \\
\hline $\begin{array}{l}-A-2- \\
-A-2-\end{array}$ & 37.26 & 59.58 & 3.13 & 99.97 & $\begin{array}{l}3.23 \\
4.91\end{array}$ \\
\hline $\begin{array}{l}-A-2-2 \\
-A-2-3\end{array}$ & 37.36 & 60.85 & 1.60 & 99.81 & $\begin{array}{l}\begin{array}{l}4.91 \\
2.51\end{array}\end{array}$ \\
\hline $\begin{array}{l}-A-2-3 \\
-A-3-1\end{array}$ & 36.83 & 60.30 & 1.75 & 98.88 & 2.78 \\
\hline $\begin{array}{l}-A-3-1 \\
-A-3-2\end{array}$ & 37.18 & 60.48 & 2.17 & 99.83 & $3.4 \mathrm{I}$ \\
\hline $\begin{array}{l}-A-3-2 \\
-A-4-1\end{array}$ & 37.11 & 59.51 & 2.92 & 99.54 & 4.61 \\
\hline $\begin{array}{l}-A-4-1 \\
-A-4-2\end{array}$ & $\begin{array}{l}36.95 \\
36.85\end{array}$ & $\begin{array}{l}60.43 \\
60.62\end{array}$ & $\begin{array}{l}1.70 \\
1.67\end{array}$ & $\begin{array}{l}99.08 \\
99.14\end{array}$ & $\begin{array}{l}2.70 \\
2.65\end{array}$ \\
\hline$-A-4-3$ & 36.95 & 61.19 & 1.45 & 99.59 & $\begin{array}{l}2.65 \\
2.28\end{array}$ \\
\hline$-1-2-1$ & 37.99 & 62.86 & 0.50 & 101.35 & $\begin{array}{l}2.28 \\
0.78\end{array}$ \\
\hline$-1-2-2$ & 37.45 & 60.80 & 1.47 & 99.72 & 2.32 \\
\hline$-1-2-3$ & 37.10 & 60.89 & 1.54 & 99.53 & 2.42 \\
\hline$-1-2-4$ & 37.79 & 63.09 & 0.42 & 101.30 & 0.65 \\
\hline$-1-4-1$ & 37.99 & 62.76 & 0.56 & 101.31 & 0.86 \\
\hline$-1-4-2$ & 37.61 & 60.01 & 2.31 & 99.93 & 3.64 \\
\hline$-2-2-6$ & 37.05 & 59.74 & 1.67 & 98.46 & 2.64 \\
\hline$-2-2-7$ & 37.62 & 60.51 & 1.53 & 99.66 & 2.42 \\
\hline$-2-2-10$ & 37.73 & 60.55 & 1.75 & 100.03 & 2.74 \\
\hline$-C-2-1-4$ & 37.13 & 60.47 & 2.66 & 100.26 & 4.14 \\
\hline$-C-2-4-4$ & 36.47 & 60.36 & 1.64 & 98.47 & 2.60 \\
\hline$-C-1-2-3$ & 36.52 & 59.29 & 2.46 & 98.27 & 3.90 \\
\hline$-C-1-2-4$ & 36.40 & 59.57 & 2.37 & 98.34 & 3.74 \\
\hline$-\mathrm{A}-1-\mathrm{B}-3$ & 37.03 & 59.19 & 3.18 & 99.40 & 4.98 \\
\hline$-c-3-1-4$ & 37.37 & 62.15 & 1.32 & 100.84 & 2.04 \\
\hline$\frac{1}{62} 1080-A-1-1$ & & 62.52 & & 101.24 & \\
\hline$-A-1-2$ & 37.70 & 63.3 & & 101. & \\
\hline$-A-1-3$ & 37.87 & 62.94 & 0.80 & 101.61 & 1.23 \\
\hline$-A-1-4$ & 37.63 & $\begin{array}{l}02.94 \\
62.16\end{array}$ & $\begin{array}{l}0.80 \\
1.03\end{array}$ & 100.82 & $\begin{array}{l}1.253 \\
1.60\end{array}$ \\
\hline$-A-1-5$ & 37.76 & 61.40 & 2.22 & 101.38 & 3.44 \\
\hline$-A-2-1$ & 37.91 & 62.63 & 1.06 & 101.60 & 1.63 \\
\hline$-A-2-2$ & 37.74 & $\begin{array}{l}61.52 \\
61.52\end{array}$ & $\begin{array}{l}1.73 \\
1.73\end{array}$ & 100.99 & $\begin{array}{l}2.033 \\
2.69\end{array}$ \\
\hline$-A-2-3$ & 37.79 & 62.28 & $\begin{array}{l}1.04 \\
1.04\end{array}$ & 101.11 & $\begin{array}{l}1.62 \\
\end{array}$ \\
\hline$-A-2-4$ & 37.67 & 62.04 & $\begin{array}{l}1.72 \\
1.72\end{array}$ & 101.43 & 2.65 \\
\hline$-A-2-5$ & 37.98 & 62.38 & $\begin{array}{l}1.52 \\
1.52\end{array}$ & 101.88 & 2.34 \\
\hline$-A-3$ & 37.46 & 61.45 & 1.21 & 100.12 & 1.90 \\
\hline$-A-3-2$ & 37.36 & 61.76 & 1.22 & 100.34 & 1.90 \\
\hline$-A-3-$ & 37.64 & 62.74 & 0.79 & 101.17 & 1.22 \\
\hline$-A-3-4$ & 37.18 & 62.53 & 1.02 & 100. & 1.5 \\
\hline$-A-3-$ & 37.34 & 61.61 & 1.11 & 100. & 1.74 \\
\hline$-B-1-1$ & 37.17 & 62.10 & 0.8 & 100. & 1.40 \\
\hline$-B-1-3$ & 37.17 & 61.97 & 1.08 & 100. & 1.69 \\
\hline$-B-1-4$ & 36.82 & 61.27 & 1.45 & 99.54 & 2.26 \\
\hline$-B-1-5$ & 37.26 & 62.13 & 1.04 & 100.43 & 1.62 \\
\hline -B-1-6 & 36.82 & 61.19 & 1.31 & 99.32 & 2.06 \\
\hline$-B-2-1$ & 37.17 & 60.79 & 2.06 & 100.02 & 3.23 \\
\hline$-B-2-2$ & 36.75 & 60.55 & 2.25 & 99.55 & 3.53 \\
\hline$-B-2-3$ & 37.04 & 60.85 & 2.08 & 99.97 & 3.26 \\
\hline$-\mathrm{B}-2-4$ & 37.12 & 61.54 & 1.81 & 100.47 & 2.81 \\
\hline $\begin{array}{l}-B-2- \\
-B-3-\end{array}$ & 36.85 & 60.63 & 2.18 & 99.66 & 3.41 \\
\hline & 36.82 & 58.85 & & 99.36 & 5.81 \\
\hline
\end{tabular}

\begin{tabular}{|c|c|c|c|c|c|}
\hline & & & & & \\
\hline & $\mathrm{s}$ & $M_{n}$ & $\mathrm{Fe}$ & Total & Fes mol. \\
\hline$-B-3-2$ & 36.90 & 59.18 & 3.70 & 99.78 & 5.79 \\
\hline$-B-3-3$ & 37.01 & 59.25 & 3.44 & 99.70 & 5.40 \\
\hline $\begin{array}{l}-B-3-4 \\
-8-3-5\end{array}$ & 37.06 & 59.75 & 3.57 & 100.38 & 5.55 \\
\hline $\begin{array}{l}-B-3-5 \\
-B-3-6\end{array}$ & 37.11 & 58.98 & 3.68 & 99.77 & 5.78 \\
\hline $\begin{array}{l}-B-3-6 \\
-B-3-7\end{array}$ & 37.12 & 59.71 & 3.53 & 100.36 & 5.50 \\
\hline $\begin{array}{l}-B-3-7 \\
-B-3-8\end{array}$ & 36.62 & 58.65 & 3.62 & 98.89 & 5.72 \\
\hline $\begin{array}{l}-B-3-8 \\
-B-3-9\end{array}$ & 36.46 & $\begin{array}{l}59.12 \\
59.36\end{array}$ & 3.67 & 99.25 & 5.75 \\
\hline $\begin{array}{l}-B-3-9 \\
-B-3-10\end{array}$ & & & $\begin{array}{l}3.59 \\
3.61\end{array}$ & 99.66 & $\begin{array}{l}5.62 \\
5.58\end{array}$ \\
\hline Yamanaka & & 60.22 & & 101.18 & 5.58 \\
\hline $\begin{array}{c}A-1-1 \\
-1-2\end{array}$ & 37.95 & 61.65 & 2.27 & 101.87 & 3.49 \\
\hline$-1-2$ & 37.65 & 61.13 & 2.42 & 101.20 & 3.74 \\
\hline$-2-1$ & 37.42 & 61.24 & 2.67 & 101.33 & 4.12 \\
\hline$-2-2$ & 37.54 & 61.13 & 2.70 & 101.37 & 4.16 \\
\hline$-3-1$ & 37.45 & 61.07 & 2.83 & 101.35 & 4.36 \\
\hline$-3-2$ & 37.39 & 61.48 & 2.75 & 101.62 & 4.21 \\
\hline$\frac{1}{5707} 33-1-1$ & 37.33 & 62.53 & 0.20 & 100.06 & 0.31 \\
\hline$-1-2$ & 37.89 & 63.38 & 0.21 & $\begin{array}{l}101.48 \\
\end{array}$ & 0.33 \\
\hline$-1-5$ & 37.61 & 63.28 & 0.19 & 101.08 & 0.29 \\
\hline$-4-3$ & 35.90 & 61.74 & 0.38 & 98.02 & 0.59 \\
\hline$-4-4$ & 36.77 & 62.46 & 0.29 & 99.52 & 0.45 \\
\hline $570739-2-1-2$ & 36.96 & 59.29 & 3.46 & 99.71 & 5.42 \\
\hline Nakanoyama & 37.22 & 59.87 & 3.48 & 100.57 & 5.40 \\
\hline$\frac{570746-1-1}{57076}$ & 37.00 & 62.92 & 0.47 & 100.39 & 0.72 \\
\hline$-1-2$ & 37.09 & 63.73 & 0.47 & 101.29 & 0.72 \\
\hline$-3-1$ & 37.45 & 63.53 & 0.54 & 101.52 & 0.83 \\
\hline$-4-1$ & 37.24 & 63.12 & 0.63 & 100.99 & 0.98 \\
\hline$-5-1$ & 37.34 & 63.45 & 0.89 & 101.68 & 1.36 \\
\hline$-5-2$ & 37.31 & 62.89 & 0.83 & 101.03 & 1.28 \\
\hline $\begin{array}{l}-6-1 \\
-6-2\end{array}$ & 37.43 & 63.19 & 0.57 & 101.19 & 0.89 \\
\hline Rito & 37.35 & & & & \\
\hline $570741-2-1$ & & & & & \\
\hline$-2-2$ & .84 & 63. & 0.2 & 100. & 0.39 \\
\hline$-2-3$ & .07 & 63.28 & 0.2 & 100.62 & 0.41 \\
\hline$-3-1$ & 37.29 & 63.85 & 0.24 & 101.38 & 0.37 \\
\hline$-3-2$ & 37.34 & 63.41 & 0.29 & 101.04 & 0.44 \\
\hline$-3-3$ & 37. & 63.57 & 0.32 & 101.52 & 0.48 \\
\hline$-4-1$ & & 63.24 & 0.30 & 101.09 & 0.46 \\
\hline$-4-2$ & 37.42 & 63.17 & 0.2 & 100 & 0.41 \\
\hline$-4-3$ & 37.03 & 63.87 & 0.2 & 101.12 & 0.34 \\
\hline$-5-1$ & & 63. & 0.4 & 101.31 & \\
\hline-5 & & 63. & 0. & 101 & \\
\hline$-5-3$ & 37. & 63. & 0. & 101 & 0. \\
\hline $570742-1-1$ & .33 & 63. & 0.2 & 102 & 0.32 \\
\hline$-3-1$ & 37.5 & 64. & 0.5 & 102 & \\
\hline$-3-2$ & 37.77 & 64.3 & 0.69 & 102.77 & 1.05 \\
\hline $570743-1-1$ & 37.14 & 63.29 & 1.01 & 101.44 & 1.54 \\
\hline$-1-2$ & 37.34 & 62.48 & 1.25 & 101.07 & 1.93 \\
\hline$-1-3$ & 37.43 & 62.16 & 1.27 & 100.86 & 1.96 \\
\hline$-1-4$ & 37.22 & 63.04 & 1.10 & 101.36 & 1.68 \\
\hline $\begin{array}{l}-1-5 \\
-2-1\end{array}$ & $\begin{array}{l}36.87 \\
37.42\end{array}$ & $\begin{array}{l}62.45 \\
62.72\end{array}$ & $\begin{array}{l}0.72 \\
1.08\end{array}$ & $\begin{array}{l}100.04 \\
101.22\end{array}$ & $\begin{array}{l}1.12 \\
1.66\end{array}$ \\
\hline
\end{tabular}




\begin{tabular}{|c|c|c|c|c|c|}
\hline & $\mathrm{s}$ & & & Total & $\mathrm{FeS} \mathrm{Mo1.8}$ \\
\hline$-2-2$ & & & & 100.91 & \\
\hline $\begin{array}{l}-2-3 \\
-2-4\end{array}$ & $\begin{array}{l}37.41 \\
37.42\end{array}$ & $\begin{array}{l}62.64 \\
62.68\end{array}$ & $\begin{array}{l}1.15 \\
0.93\end{array}$ & $\begin{array}{l}101.20 \\
101.03\end{array}$ & $\begin{array}{l}1.77 \\
1.44\end{array}$ \\
\hline$-2-5$ & & & & & \\
\hline $\begin{array}{r}\text { owa } \\
570708-2-1 \\
-2-2\end{array}$ & 35.84 & 63.49 & & 99.51 & 0.27 \\
\hline $\begin{array}{l}-2-2 \\
-3-1 \\
-3-2\end{array}$ & $\begin{array}{l}\begin{array}{l}35.86 \\
36.42\end{array} \\
36.42\end{array}$ & $\begin{array}{l}63.11 \\
63.73\end{array}$ & $\begin{array}{l}0.17 \\
0.17\end{array}$ & $\begin{array}{r}99.14 \\
100.32\end{array}$ & $\begin{array}{l}0.26 \\
0.25\end{array}$ \\
\hline $\begin{array}{l}-3-2 \\
-4-1\end{array}$ & 34.60 & 63.78 & 0.18 & 98.56 & 0.27 \\
\hline $\begin{array}{r}-4-1 \\
-4-2\end{array}$ & $\begin{array}{l}\begin{array}{l}36.06 \\
36.21\end{array} \\
36.21\end{array}$ & $\begin{array}{l}63.62 \\
63.64\end{array}$ & $\begin{array}{l}0.17 \\
0.18\end{array}$ & $\begin{array}{r}99.85 \\
100.03 \\
\end{array}$ & $\begin{array}{l}0.26 \\
0.27\end{array}$ \\
\hline $\begin{array}{r}570706-1-1 \\
-1-2\end{array}$ & $\begin{array}{l}36.21 \\
37.30\end{array}$ & $\begin{array}{l}03.25 \\
63.25\end{array}$ & 0.14 & $\begin{array}{l}100.693 \\
100.69\end{array}$ & $\begin{array}{l}0.27 \\
0.21\end{array}$ \\
\hline $\begin{array}{l}-1-2 \\
-1-3 \\
-2-1\end{array}$ & $\begin{array}{l}\begin{array}{l}37.48 \\
36.81\end{array} \\
\end{array}$ & $\begin{array}{l}63.27 \\
63.50\end{array}$ & $\begin{array}{l}0.24 \\
0.23\end{array}$ & $\begin{array}{l}100.99 \\
100.54\end{array}$ & $\begin{array}{l}0.36 \\
0.35\end{array}$ \\
\hline $\begin{array}{l}-2-1 \\
-2-2\end{array}$ & & $\begin{array}{l}63.54 \\
63.26\end{array}$ & $\begin{array}{l}0.20 \\
0.21\end{array}$ & $\begin{array}{l}101.12 \\
100.74\end{array}$ & $\begin{array}{l}0.30 \\
0.32\end{array}$ \\
\hline & 37.59 & $\begin{array}{l}\text { (b. } \\
63.68 \\
6.26\end{array}$ & 0.19 & $\begin{array}{l}101.46 \\
\end{array}$ & $\begin{array}{l}0.32 \\
0.29\end{array}$ \\
\hline $\begin{array}{l}-3-1 \\
-3-2 \\
-3-2\end{array}$ & 36.99 & $\begin{array}{l}63.44 \\
63.49\end{array}$ & 0.17 & $\begin{array}{l}100.60 \\
100.56\end{array}$ & 0.26 \\
\hline$-3-3$ & 37.07 & $\begin{array}{l}\text { (2.51 } \\
63.51\end{array}$ & 0.24 & $\begin{array}{l}100.82 \\
\end{array}$ & $\begin{array}{l}0.37 \\
0.37\end{array}$ \\
\hline $\begin{array}{r}570704-2-1 \\
-2-3\end{array}$ & $\begin{array}{l}36.19 \\
36.46\end{array}$ & $\begin{array}{l}62.49 \\
62.31\end{array}$ & $\begin{array}{l}0.50 \\
0.51\end{array}$ & $\begin{array}{l}99.18 \\
99.28\end{array}$ & $\begin{array}{l}0.79 \\
0.81\end{array}$ \\
\hline $\begin{array}{l}570710-3 \\
-5\end{array}$ & 36.28 & 63.60 & 0.52 & 100.40 & 0.80 \\
\hline $570707-1-1$ & $\begin{array}{l}36.38 \\
36.17\end{array}$ & $\begin{array}{l}63.44 \\
61.21\end{array}$ & $\begin{array}{l}0.60 \\
2.63 \\
2.63\end{array}$ & $\begin{array}{l}100.42 \\
100.01\end{array}$ & $\begin{array}{l}0.92 \\
4.05\end{array}$ \\
\hline$-1-3$ & 36.14 & 60.91 & 2.72 & $\begin{array}{r}99.77 \\
100.03\end{array}$ & 4.21 \\
\hline $\begin{array}{l}-1-7 \\
-1-7\end{array}$ & 35.92 & $\begin{array}{l}61.11 \\
61.12\end{array}$ & $\begin{array}{l}2.53 \\
2.83 \\
\end{array}$ & $\begin{array}{r}100.03 \\
99.87\end{array}$ & 4.35 \\
\hline $\begin{array}{l}-2-1 \\
-2-2 \\
-2\end{array}$ & $\begin{array}{l}36.30 \\
36.29\end{array}$ & 63.95 & 0.20 & 100.45 & 0.30 \\
\hline & 35.88 & 63.39 & 0.19 & 99.46 & $\begin{array}{l}.24 \\
0.29\end{array}$ \\
\hline & 36.30 & 64.22 & 0.20 & 100.72 & 0.30 \\
\hline $\begin{array}{r}570709-1-5 \\
57-1\end{array}$ & $\begin{array}{l}36.21 \\
38.28\end{array}$ & $\begin{array}{l}\begin{array}{r}63.81 \\
59.09\end{array} \\
\end{array}$ & $\begin{array}{l}0.23 \\
4.03\end{array}$ & $\begin{array}{l}\begin{array}{l}100.25 \\
101.40\end{array} \\
\end{array}$ & $\begin{array}{l}0.35 \\
6.28\end{array}$ \\
\hline 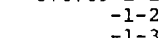 & 37.95 & 59.30 & 4.24 & 101.49 & 6.58 \\
\hline & $\begin{array}{l}37.43 \\
37.83\end{array}$ & & (3.17 & 10144 & \\
\hline & 37.22 & 59.00 & $\begin{array}{l}3.98 \\
3.98\end{array}$ & 100.20 & 6.22 \\
\hline & 37.84 & 59.16 & 4.05 & 101.05 & 6.32 \\
\hline & $\begin{array}{l}37.98 \\
77\end{array}$ & $\begin{array}{l}58.56 \\
5.56\end{array}$ & $\begin{array}{l}4.07 \\
4.09\end{array}$ & 100.61 & \\
\hline & 列 & - 58.29 & & & \\
\hline & 37.30 & 58.20 & $\begin{array}{l}4.00 \\
4.00\end{array}$ & 99.50 & 6.33 \\
\hline $\begin{array}{l}\text { nayokogawa } \\
\text { 5208-1-1-1 }\end{array}$ & & & & & \\
\hline & 36.35 & 62.71 & 015 & & \\
\hline & 36.97 & 63.47 & 0.23 & 100.67 & 0.35 \\
\hline & $\begin{array}{l}37.29 \\
37.25\end{array}$ & $\begin{array}{l}64.31 \\
6.33\end{array}$ & $\begin{array}{l}0.18 \\
0.18\end{array}$ & $\begin{array}{l}100.76 \\
100\end{array}$ & \\
\hline & 36.87 & & & & \\
\hline & 37.26 & 63.22 & 0.18 & 100.66 & 0.2 \\
\hline & $\begin{array}{l}37.21 \\
37\end{array}$ & 63.14 & 0.20 & 100.55 & 0. \\
\hline$-2-2-3$ & 37.39 & $\begin{array}{l}63.44 \\
63.73\end{array}$ & 0.17 & 101.29 & 0.26 \\
\hline $\begin{array}{r}-2-3-1 \\
5205-1-1-2\end{array}$ & $\begin{array}{l}36.79 \\
37.54\end{array}$ & $\begin{array}{l}64.23 \\
63.94\end{array}$ & 0.33 & $\begin{array}{l}101.22 \\
101.81\end{array}$ & 0.50 \\
\hline
\end{tabular}

A-3

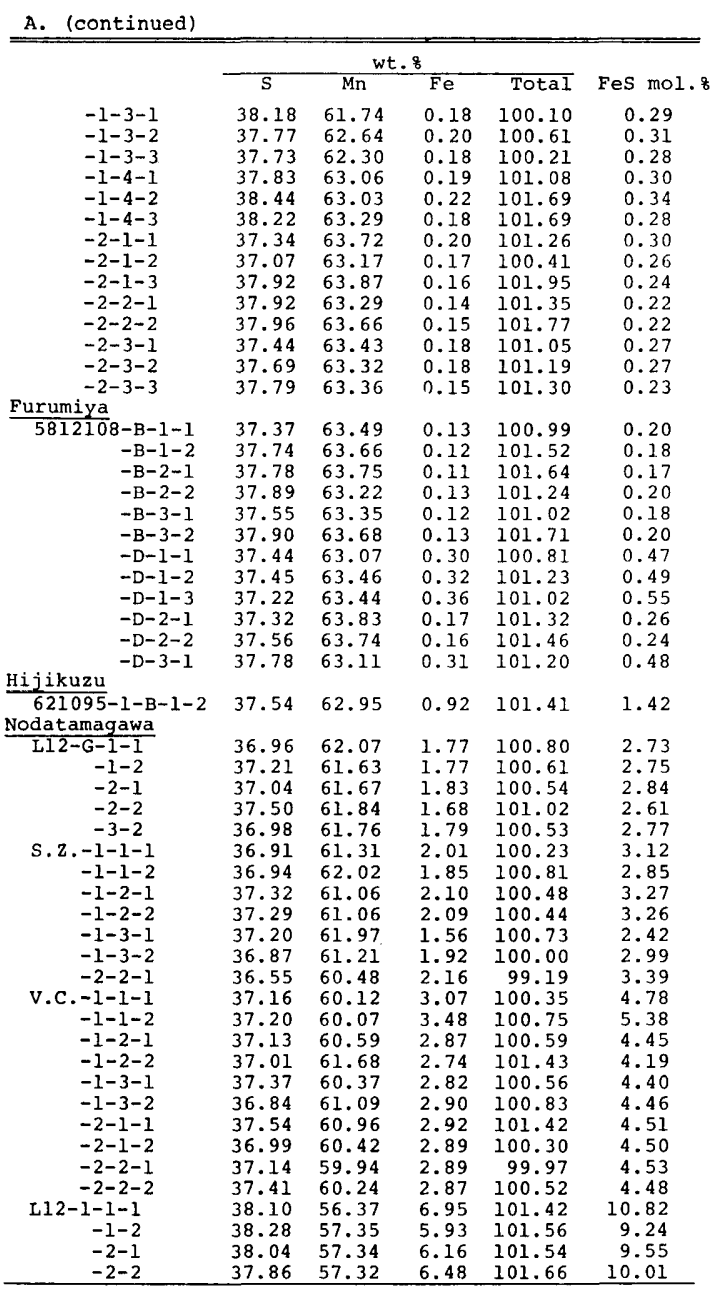




\begin{tabular}{|c|c|c|c|c|c|}
\hline & A. (continued) & \multicolumn{3}{|c|}{ wt. 8} & \multirow[b]{2}{*}{ Fes mol. 8} \\
\hline & $\mathrm{s}$ & $\mathrm{Mn}$ & $\mathrm{Fe}$ & Total & \\
\hline $\begin{array}{l}-2-A \\
-3-1\end{array}$ & 35.44 & 58.54 & 5.55 & 99.53 & 8.53 \\
\hline $\begin{array}{l}-3-1 \\
-3-2\end{array}$ & 37.43 & $\begin{array}{l}56.95 \\
56.00\end{array}$ & $\begin{array}{l}7.13 \\
7.14\end{array}$ & 101.51 & 10.97 \\
\hline $\begin{array}{r}-3-2 \\
-2-1-\mathrm{A}\end{array}$ & $\begin{array}{l}37.67 \\
37.79\end{array}$ & $\begin{array}{l}56.00 \\
55.41\end{array}$ & $\begin{array}{l}7.14 \\
7.89\end{array}$ & $\begin{array}{l}100.81 \\
101.09\end{array}$ & $\begin{array}{l}11.14 \\
12.28\end{array}$ \\
\hline$-1-B$ & 37.38 & 55.80 & 7.43 & 100.61 & $\begin{array}{l}12.28 \\
11.59\end{array}$ \\
\hline$-2-1$ & 37.54 & 55.85 & 7.24 & 100.63 & $\begin{array}{l}11.59 \\
11.31\end{array}$ \\
\hline $\begin{array}{l}-2-2 \\
-2-x\end{array}$ & 37.72 & 57.14 & 6.16 & 101.02 & 9.58 \\
\hline $\begin{array}{l}-2-A \\
-2-B\end{array}$ & 37.91 & 56.73 & 6.71 & 101.35 & 10.43 \\
\hline $\begin{array}{l}-2-B \\
-3-B\end{array}$ & $\begin{array}{l}38.44 \\
37.59\end{array}$ & 57.20 & 6.06 & 101.70 & 9.45 \\
\hline v. $0 .-^{-3-B}-1-1$ & 37.59 & 61.92 & 1.84 & 101.35 & 2.84 \\
\hline$-1-1-2$ & $\begin{array}{l}\begin{array}{l}37.01 \\
37.54\end{array}\end{array}$ & 56.19 & 7.46 & 100.66 & 11.55 \\
\hline$-1-2-1$ & $\begin{array}{l}37.54 \\
37.29\end{array}$ & $\begin{array}{l}56.02 \\
54.99\end{array}$ & $7 \cdot 39$ & 100.95 & 11.48 \\
\hline$-1-2-2$ & 37.34 & $\begin{array}{l}54.99 \\
55.38\end{array}$ & 7.70 & 99.98 & 12.11 \\
\hline$-3-1-1$ & 37.15 & $\begin{array}{l}55.38 \\
57.41\end{array}$ & 7.25 & 99.97 & 11.41 \\
\hline$-3-1-2$ & 37.18 & $\begin{array}{l}57.41 \\
56.47\end{array}$ & $\begin{array}{l}7.24 \\
7.26\end{array}$ & $\begin{array}{l}101.80 \\
100.91\end{array}$ & 11.03 \\
\hline \multicolumn{6}{|l|}{ Kaso } \\
\hline $28-2-1-1$ & 37.52 & 63.68 & 0.28 & 101.48 & 0.42 \\
\hline$-2-1-2$ & 37.61 & 63.06 & 0.34 & $\begin{array}{l}101.08 \\
101.01\end{array}$ & $\begin{array}{l}0.42 \\
0.52\end{array}$ \\
\hline$-2-2-1$ & 37.67 & 63.75 & 0.34 & 101.76 & 0.51 \\
\hline$-2-2-2$ & 37.56 & 63.55 & 0.37 & 101.48 & 0.56 \\
\hline $29-2-2-2$ & 37.91 & 63.69 & 0.33 & 101.93 & 0.50 \\
\hline $22-B-2-1-1$ & 37.65 & 62.48 & 1.48 & 101.61 & 2.27 \\
\hline$-2-1-2$ & 37.51 & 62.61 & 1.47 & 101.59 & 2.27 \\
\hline$-2-1-3$ & 37.99 & 62.54 & 1.30 & 101.83 & 2.00 \\
\hline$-2-2-1$ & 36.81 & 62.46 & 1.06 & 100.33 & 1.64 \\
\hline$-2-2-3$ & 37.57 & 63.06 & 1.03 & 101.66 & 1.58 \\
\hline$-2-3-1$ & 37.46 & 62.41 & 1.23 & 101.10 & 1.90 \\
\hline \multicolumn{2}{|l|}{ Hagidaira } & 62.75 & 1.22 & 101.35 & \\
\hline $570728-1$ & 36.58 & 63.74 & 0.19 & 100.51 & 0.28 \\
\hline-2 & 37.04 & 64.03 & 0.20 & 101.27 & 0.31 \\
\hline $570730-3$ & 36.49 & 63.62 & 0.19 & 100.30 & 0.29 \\
\hline $\begin{array}{l}570730-2 \\
-3\end{array}$ & 36.72 & 62.58 & 0.21 & 99.51 & 0.32 \\
\hline $\begin{array}{l}-3 \\
-4\end{array}$ & $\begin{array}{l}36.35 \\
35.90\end{array}$ & 61.71 & 0.26 & 98.32 & 0.41 \\
\hline $570717^{-4}-1-7$ & 35.90 & 62.43 & 0.28 & 98.61 & 0.43 \\
\hline $\begin{array}{r}570717-1-1 \\
-1-2\end{array}$ & 36.30 & 63.17 & 0.33 & 99.80 & 0.51 \\
\hline $\begin{array}{l}-1-2 \\
-1-3\end{array}$ & $\begin{array}{l}35.98 \\
36.13\end{array}$ & 62.62 & 0.32 & 98.92 & 0.49 \\
\hline $\begin{array}{l}-1-3 \\
-2-1\end{array}$ & $\begin{array}{l}36.13 \\
35.88\end{array}$ & 62.63 & 0.32 & 99.08 & 0.49 \\
\hline $\begin{array}{l}-2-1 \\
-2-2\end{array}$ & $\begin{array}{l}35.88 \\
36.70\end{array}$ & $\begin{array}{l}63.43 \\
62.56\end{array}$ & 0.36 & 99.67 & 0.55 \\
\hline $570719-4-1$ & $\begin{array}{l}36.70 \\
36.34\end{array}$ & $\begin{array}{l}62.56 \\
61.91\end{array}$ & 0.37 & 99.63 & 0.57 \\
\hline$-4-2$ & $\begin{array}{l}36.34 \\
36.36\end{array}$ & $\begin{array}{l}61.91 \\
61.78\end{array}$ & 0.71 & 98.96 & 1.12 \\
\hline$-4-3$ & $\begin{array}{l}36.36 \\
36.40\end{array}$ & $\begin{array}{l}61.78 \\
61.70\end{array}$ & $\begin{array}{l}0.68 \\
0.69\end{array}$ & $\begin{array}{l}98.82 \\
98.79\end{array}$ & 1.08 \\
\hline $570720-2-1$ & 36.74 & 61.94 & 0.80 & $\begin{array}{l}98.79 \\
99.48\end{array}$ & $\begin{array}{l}1.10 \\
1.26\end{array}$ \\
\hline$-2-2$ & 36.59 & 61.49 & 0.80 & 98.88 & $\begin{array}{l}1.26 \\
1.27\end{array}$ \\
\hline$-2-3$ & 36.66 & 62.12 & 0.87 & 99.65 & 1.37 \\
\hline $570724-1$ & 36.37 & 59.98 & 1.81 & 98.16 & 2.89 \\
\hline-2 & 37.51 & 60.50 & 1.88 & 99.89 & $\begin{array}{l}2.97 \\
2.97\end{array}$ \\
\hline-4 & 35.69 & 63.12 & 0.63 & 99.44 & 0.98 \\
\hline${ }^{-5}$ & 36.83 & 62.55 & 0.69 & 100.07 & 1.08 \\
\hline $570718-1-1$ & 36.69 & 61.35 & 1.18 & 99.22 & 1.86 \\
\hline$-1-2$ & 36.87 & 61.79 & 1.25 & 99.91 & 1.95 \\
\hline $5707-3$ & 37.25 & 61.42 & 1.19 & 99.86 & 1.88 \\
\hline $\begin{array}{r}570716-3-1 \\
-3-2\end{array}$ & 36.70 & 61.00 & 1.53 & 99.23 & 2.40 \\
\hline$-3-2$ & 36.09 & 60.85 & 1.60 & 98.54 & 2.52 \\
\hline
\end{tabular}

A. (continued)

\begin{tabular}{|c|c|c|c|c|c|c|}
\hline & & \multirow[b]{2}{*}{$\mathrm{FeS} \mathrm{mo} 1.8$} \\
\hline & & $\mathrm{s}$ & $\mathrm{Mn}$ & $\mathrm{Fe}$ & Total & \\
\hline & $-3-3$ & 36.49 & 60.94 & 1.50 & 98.93 & 2.36 \\
\hline 570721 & $\begin{array}{l}-2-1 \\
-2-2\end{array}$ & $\begin{array}{l}37.00 \\
36.15\end{array}$ & $\begin{array}{l}58.68 \\
58.90\end{array}$ & 4.94 & 100.62 & 7.64 \\
\hline & $\begin{array}{l}-2-2 \\
-2-3\end{array}$ & 37.43 & $\begin{array}{l}58.90 \\
59.49\end{array}$ & $\begin{array}{l}4.88 \\
4.38\end{array}$ & 99.93 & 7.55 \\
\hline & $-2-4$ & 36.16 & 59.21 & 5.21 & $\begin{array}{l}101.30 \\
100.58\end{array}$ & $\begin{array}{l}6.75 \\
7.96\end{array}$ \\
\hline & $-3-1$ & 36.60 & 59.10 & 4.27 & 99.97 & $\begin{array}{l}1.96 \\
6.65\end{array}$ \\
\hline & $-3-2$ & 36.14 & 59.11 & $\begin{array}{l}3.91 \\
3.91\end{array}$ & 99.16 & $\begin{array}{l}0.03 \\
6.11\end{array}$ \\
\hline & $-3-3$ & 36.92 & 58.99 & 4.09 & 100.00 & 6.38 \\
\hline 570725 & $-1-7$ & 35.81 & 57.70 & 5.68 & 99.19 & $\begin{array}{l}8.30 \\
8.83\end{array}$ \\
\hline & $-1-8$ & 35.03 & 57.55 & 6.18 & 98.76 & 9.56 \\
\hline & $-2-1$ & 37.08 & 56.46 & 6.32 & 99.86 & 9.92 \\
\hline & $-2-2$ & 37.37 & 57.04 & 5.82 & 100.23 & 9.12 \\
\hline & $-2-3$ & 37.25 & 57.27 & 5.90 & 100.42 & 9.20 \\
\hline & $-2-4$ & 37.58 & 57.21 & 5.69 & 100.48 & 8.91 \\
\hline & $-2-5$ & 37.01 & 56.39 & 6.39 & 99.79 & 10.04 \\
\hline & $-3-1$ & 36.53 & 56.72 & 5.62 & 98.87 & 8.87 \\
\hline & $-3-2$ & 36.81 & 57.44 & 5.35 & 99.60 & 8.39 \\
\hline & $-3-3$ & 36.74 & 57.20 & 5.52 & 99.46 & 8.67 \\
\hline & $-3-4$ & 36.18 & 58.08 & 5.49 & 99.75 & 8.51 \\
\hline & $-3-5$ & 36.87 & 56.89 & 5.59 & 99.35 & 8.81 \\
\hline & $-4-1$ & 36.66 & 57.21 & 5.80 & 99.67 & 9.07 \\
\hline & $-4-2$ & 36.44 & 57.20 & 5.67 & 99.31 & 8.89 \\
\hline & $-4-3$ & 36.74 & 57.01 & 5.84 & 99.59 & 9.16 \\
\hline & $-4-4$ & 36.85 & 57.50 & 5.57 & 99.92 & 8.69 \\
\hline & $-4-5$ & 36.68 & 57.37 & 5.91 & 99.96 & 9.20 \\
\hline & $\begin{array}{l}-5-1 \\
-5-2\end{array}$ & $\begin{array}{l}37.09 \\
36.67\end{array}$ & 57.83 & 5.28 & 100.20 & 8.24 \\
\hline & $\begin{array}{l}-5-2 \\
-5-3\end{array}$ & & 57.34 & & 99.07 & \\
\hline & $\begin{array}{l}-5-3 \\
-5-6\end{array}$ & 36.82 & & $\begin{array}{l}5.31 \\
5.51\end{array}$ & 99.54 & 8.34 \\
\hline & $\begin{array}{l}-5-1 \\
-6-1\end{array}$ & 35.81 & 58.09 & $\begin{array}{l}5.51 \\
5.51\end{array}$ & 101.11 & 8.53 \\
\hline & $-6-2$ & $\begin{array}{l}35.86 \\
36.16\end{array}$ & $\begin{array}{l}57.99 \\
57.83\end{array}$ & $\begin{array}{l}5.51 \\
5.50\end{array}$ & $\begin{array}{l}99.36 \\
99.49\end{array}$ & $\begin{array}{l}8.55 \\
8.55\end{array}$ \\
\hline Yamada & & & & & & \\
\hline & & 37.45 & 59.82 & 3.46 & 100.73 & 5.38 \\
\hline & & & & & & \\
\hline$-2-1$ & & 37.55 & 59.07 & 3.51 & 100.13 & 5.53 \\
\hline & & 37.36 & 60.16 & 3.66 & 101.18 & 5.65 \\
\hline$-2-3$ & & 37.19 & 60.28 & 3.17 & 100.64 & 4.92 \\
\hline & & 37.70 & 60.43 & 3.75 & 101.88 & 5.76 \\
\hline$-3-2$ & & 37.69 & 59.98 & 3.67 & 101.34 & 5.67 \\
\hline Fukadan & & 37.61 & 59.44 & 3.74 & 100.79 & 5.82 \\
\hline 501228 & & & & & & \\
\hline & $-1-2-1$ & 37.54 & 54.70 & 8.66 & 100.90 & 13.47 \\
\hline & $-1-2-2$ & 37.72 & 55.28 & 7.87 & 100.87 & 12.29 \\
\hline & $-1-3-1$ & 37.66 & 55.92 & 7.14 & 100.72 & 11.16 \\
\hline & $-1-5-1$ & 37.43 & 55.07 & 8.29 & 100.79 & 12.89 \\
\hline & $-3-3-1$ & 37.80 & 56.47 & 7.41 & 101.68 & 11.43 \\
\hline & $-3-3-2$ & 37.74 & 56.77 & 7.31 & 101.82 & 11.24 \\
\hline & $-4-4-1$ & 37.27 & 56.91 & 7.43 & 101.61 & 11.38 \\
\hline & $-4-4-2$ & 37.39 & 57.45 & 6.72 & 101.56 & 10.31 \\
\hline & $-4-4$ & 37.40 & 56.81 & 7.08 & 101.29 & 10.91 \\
\hline Fukumal & $-5-5$ & 37.76 & & 7.16 & 101.74 & 11.03 \\
\hline 571151 & $6-2-1$ & & & & & \\
\hline & $-3-1$ & 37.31 & 63.23 & 0.18 & 100.72 & 0.27 \\
\hline & $-3-2$ & 37.01 & 63.12 & 0.26 & 100.39 & 0.40 \\
\hline
\end{tabular}




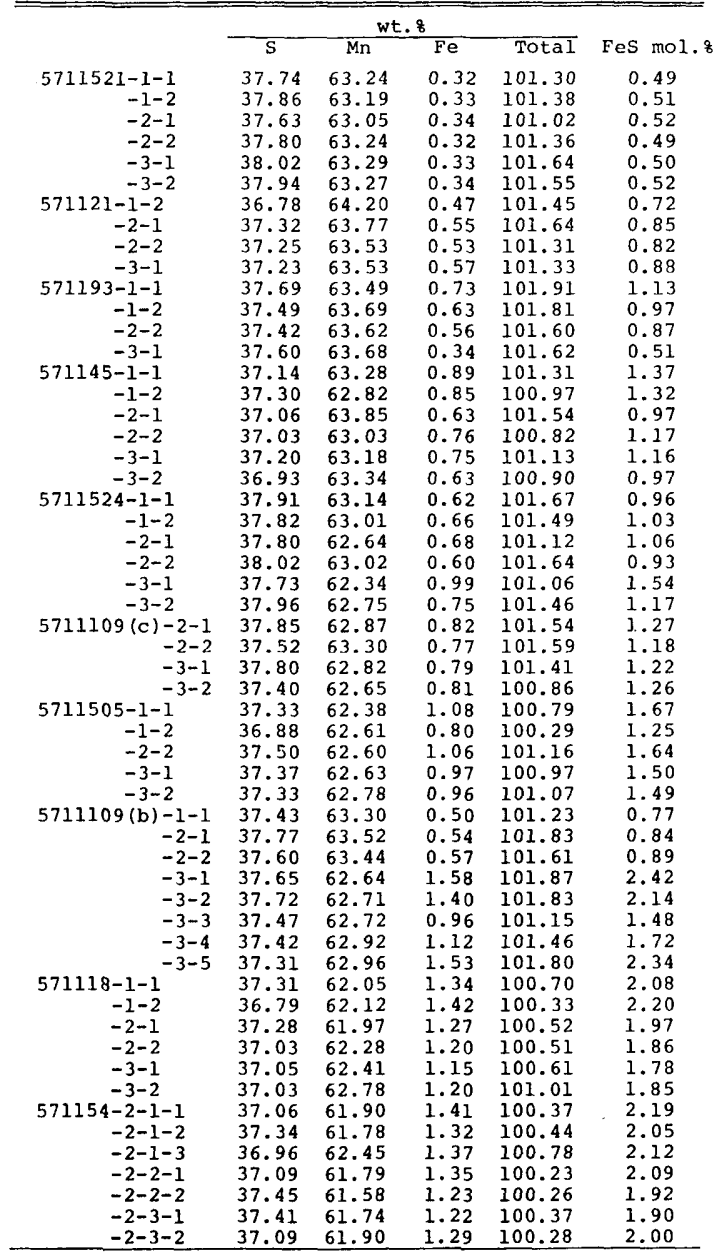

A-7
A. (continued)

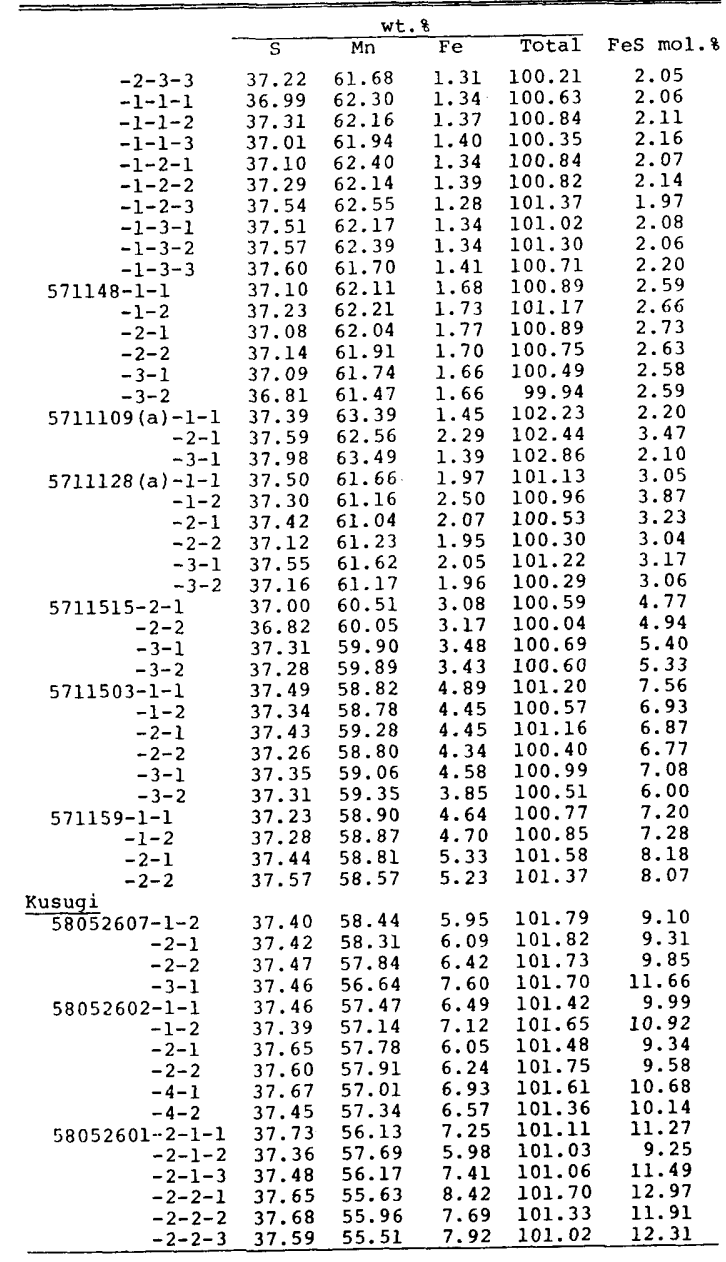




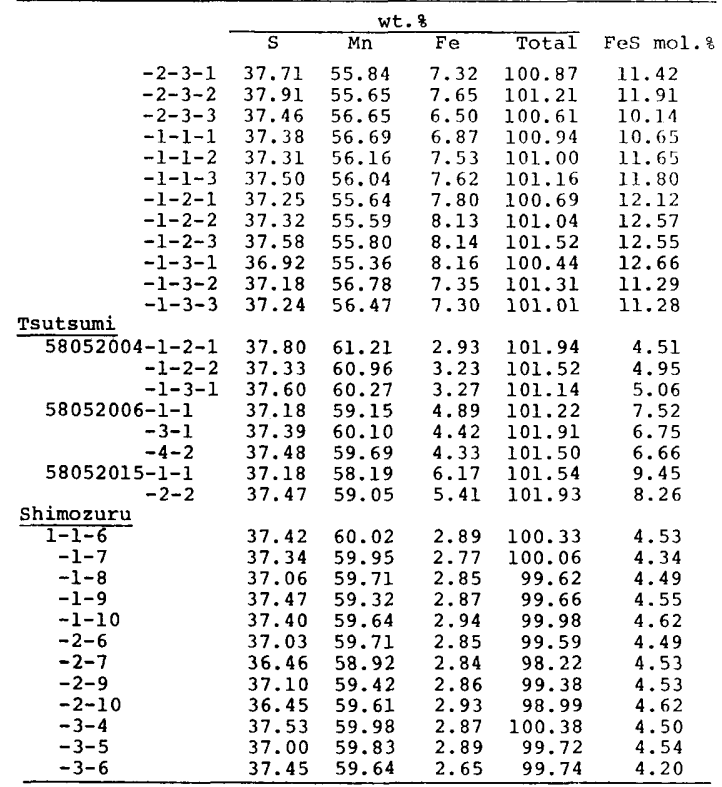

B. Sphalerite analyses

\begin{tabular}{|c|c|c|c|c|c|c|c|c|}
\hline & \multicolumn{6}{|c|}{ wt. 8} & \multicolumn{2}{|c|}{$\mathrm{mol} .8$} \\
\hline & $\bar{s}$ & Mn & $\mathrm{Fe}$ & $2 \mathrm{n}$ & $\overline{c d}$ & Total & MnS & $\mathrm{FeS}$ \\
\hline$\frac{\text { Inakuraish } \mathrm{I}}{\text { R.C. }-\mathrm{A}-2-\mathrm{A}}$ * & 33.67 & 16.05 & 4.64 & 46.03 & & 100.39 & 27.06 & 7.71 \\
\hline$-A-2-B$ & 33.94 & 16.13 & 5.12 & 45.07 & & 100.26 & 27.33 & 8.52 \\
\hline$-A-2-C *$ & 33.15 & 9.04 & 5.53 & 52.77 & & 100.49 & 15.36 & 9.25 \\
\hline$-A-3-A$ & 32.98 & 10.20 & 3.71 & 50.66 & & 97.55 & 18.08 & 6.47 \\
\hline$-A-3-B$ & 33.50 & 5.16 & 3.14 & 60.04 & & 101.84 & 8.78 & 5.27 \\
\hline$-A-3-C$ & 33.37 & 8.38 & 2.50 & 57.80 & & 102.05 & 14.11 & 4.14 \\
\hline$-1-1-1$ & 33.69 & 7.94 & 3.14 & 55.58 & 0.00 & 100.35 & 13.75 & 5.36 \\
\hline$-1-1-2$ * & 34.60 & 16.40 & 9.84 & 39.11 & 0.00 & 99.95 & 27.81 & 16.42 \\
\hline$-1-1-3$ * & 34.89 & 9.79 & 14.48 & 41.86 & 0.03 & 101.05 & 16.53 & 24.05 \\
\hline$-1-3-1$ * & 33.69 & 9.22 & 3.88 & 53.35 & 0.10 & 100.24 & 15.92 & 6.60 \\
\hline$-1-3-3 *$ & 34.14 & 7.70 & 4.68 & 53.77 & 0.07 & 100.36 & 13.39 & 8.00 \\
\hline $\begin{array}{l}-2-2-8 \text { * } \\
-1-1-7\end{array}$ & 33.91 & 10.40 & 3.14 & 55.05 & 0.00 & 102.50 & 17.39 & 5.16 \\
\hline $\begin{array}{l}-1-1-7 \\
-1-1-9\end{array}$ & $\begin{array}{l}33.34 \\
33.51\end{array}$ & $\begin{array}{l}7.50 \\
9.66\end{array}$ & $\begin{array}{l}2.91 \\
4.13\end{array}$ & $\begin{array}{l}57.06 \\
53.61\end{array}$ & & $\begin{array}{l}100.81 \\
100.91\end{array}$ & $\begin{array}{l}12.85 \\
16.44\end{array}$ & $\begin{array}{l}4.91 \\
6.91\end{array}$ \\
\hline
\end{tabular}

B. (continued)

\begin{tabular}{|c|c|c|c|c|c|c|c|c|c|}
\hline & \multicolumn{6}{|c|}{ wt. 8} & \multicolumn{2}{|c|}{ mol. 8} & \\
\hline & S & Mn & $\mathrm{Fe}$ & $2 n$ & $\overline{c d}$ & Total & $\frac{\operatorname{mol}}{\mathrm{MnS}}$ & $\frac{.8}{F e S}$ & \\
\hline$-1-1-11$ * & 34.61 & 17.47 & 8.76 & 40.76 & & 101.60 & 28.96 & 14.27 & \\
\hline $\begin{array}{l}-1-1-12 \text { * } \\
-1-1-13\end{array}$ & $\begin{array}{l}34.09 \\
34.19\end{array}$ & 14.74 & 9.64 & 42.65 & & 101.12 & 24.54 & 15.78 & \\
\hline$-1-1-14$ * & 34.24 & 15.99 & $\begin{array}{r}10.34 \\
8.84\end{array}$ & 42.01 & & 100.72 & $\begin{array}{l}27.15 \\
26.66\end{array}$ & 16.95 & \\
\hline$-1-1-15 \star$ & 33.57 & 6.05 & 8.06 & 53.31 & & 100.99 & $\begin{array}{l}26.66 \\
10.29\end{array}$ & 14.49 & \\
\hline$-1-1-16$ * & 33.32 & 5.85 & 7.63 & 54.37 & & 101.17 & 9.91 & $\begin{array}{l}13.49 \\
12.71\end{array}$ & \\
\hline$-1-1-17$ * & 33.71 & 8.89 & 9.64 & 49.40 & & $\begin{array}{l}101.17 \\
101.64\end{array}$ & $\begin{array}{r}9.91 \\
14.84\end{array}$ & 15.84 & \\
\hline$-1-1-19$ * & 33.82 & $\begin{array}{l}6.06 \\
6.66\end{array}$ & $\begin{array}{l}3.049 \\
8.49\end{array}$ & 52.57 & & $\begin{array}{l}101.64 \\
101.54\end{array}$ & $\begin{array}{l}11.84 \\
11.25\end{array}$ & $\begin{array}{l}14.84 \\
14.11\end{array}$ & \\
\hline$-1-1-20$ * & 33.59 & 6.82 & 10.18 & 50.60 & & $\begin{array}{l}101.34 \\
101.19\end{array}$ & $\begin{array}{l}11.50 \\
11.50\end{array}$ & $\begin{array}{l}14.11 \\
16.86\end{array}$ & \\
\hline$-1-5-4$ & 33.72 & 11.27 & 3.18 & 53.61 & & 101.78 & 18.96 & 5.25 & \\
\hline$\frac{-1-6-7}{4}$ & 33.89 & 1.85 & 13.21 & 51.84 & & 100.79 & 3.16 & 22.25 & \\
\hline$\frac{\text { Yamanaka }}{\bar{A}-1-2-\bar{A}}$ & 33.53 & 7006 & 4.14 & 56.64 & & 101.37 & & & $\overrightarrow{9}$ \\
\hline$-1-3-A$ & 33.13 & 7.19 & $\begin{array}{l}4.14 \\
3.61\end{array}$ & $\begin{array}{l}56.64 \\
56.43\end{array}$ & & $\begin{array}{l}101.37 \\
100.36\end{array}$ & $\begin{array}{l}12.01 \\
12.36\end{array}$ & $\begin{array}{l}6.94 \\
6.11\end{array}$ & है \\
\hline$-1-3-B$ & 33.52 & 6.65 & 3.57 & 57.57 & & 101.31 & 11.35 & 6.01 & 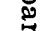 \\
\hline$-2-3-A$ & 32.97 & 7.02 & 3.41 & 54.76 & & 98.16 & 12.44 & 5.94 & 5 \\
\hline $\begin{array}{l}\text {-2-3-B } \\
\text { Nodatamagawa }\end{array}$ & 33.36 & 7.45 & 4.23 & 56.20 & & 101.24 & 12.66 & 7.06 & $\stackrel{2}{\not}$ \\
\hline S.Z.-1-2-A & 33.49 & 10.94 & 3.24 & 54.19 & & 101.86 & 18.33 & 5.34 & (1) \\
\hline$-2-1-A$ & 32.55 & 7.59 & 3.49 & 56.87 & & 100.50 & 12.90 & 5.84 & $\vec{g}$ \\
\hline$-2-2-A$ & 32.77 & 7.97 & 3.89 & 55.18 & & 99.81 & 13.70 & 6.58 & 0 \\
\hline $\begin{array}{l}-2-3-A \\
-3\end{array}$ & 32.06 & 8.04 & 3.41 & 55.39 & & 98.90 & 13.88 & 5.78 & 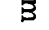 \\
\hline V.0.-3-2-1 & 33.25 & 9.79 & 14.59 & 42.13 & & 99.76 & 16.44 & 24.10 & + \\
\hline$-3-2-2$ & 33.13 & 9.03 & 14.94 & 41.66 & & 98.76 & 15.37 & 25.02 & 芦 \\
\hline$-3-2-3$ & 33.14 & 9.35 & 14.35 & 43.06 & & 99.90 & 15.68 & 23.66 & $\bar{D}$ \\
\hline$-3-2-4$ & 33.13 & 10.24 & 13.42 & 42.78 & & 99.57 & 17.24 & 22.22 & $z$ \\
\hline$-3-2-5$ & 33.07 & 9.17 & 13.40 & 43.14 & & 98.78 & 15.64 & 22.50 & $\infty$ \\
\hline$-4-2-1$ & 31.39 & 2.25 & 1.80 & 63.53 & & 98.97 & 3.92 & 3.07 & 岁 \\
\hline$-4-2-2$ & 30.91 & 2.39 & 2.16 & 63.97 & & 99.43 & 4.09 & 3.64 & $\overline{0}$ \\
\hline$-4-3-1$ & 31.47 & 4.67 & 13.86 & 47.74 & & 97.74 & 7.99 & 23.34 & 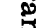 \\
\hline $\begin{array}{l}-4-3-2 \\
-4-3-3\end{array}$ & 32.22 & $\begin{array}{l}4.65 \\
6.23\end{array}$ & 12.78 & 50.14 & & 99.79 & 7.84 & 21.18 & 5 \\
\hline $\begin{array}{l}-4-3-3 \\
-4-4-1\end{array}$ & $\begin{array}{l}32.24 \\
32.64\end{array}$ & $\begin{array}{l}6.23 \\
3.05\end{array}$ & $\begin{array}{r}16.21 \\
2.95\end{array}$ & $\begin{array}{l}43.70 \\
6.53\end{array}$ & & $\begin{array}{r}98.38 \\
100.17\end{array}$ & $\begin{array}{r}10.58 \\
5.29\end{array}$ & $\begin{array}{r}27.07 \\
5.03\end{array}$ & $\begin{array}{ll}y_{2} \\
0\end{array}$ \\
\hline$-4-4-2$ & 31.62 & 2.59 & 2.36 & 64.69 & & 101.26 & 4.36 & 3.91 & \\
\hline$-4-4-3$ & 32.15 & 2.30 & 1.28 & 63.27 & & 99.00 & 4.05 & 2.22 & \\
\hline gidaira & & & & & & & & & \\
\hline $570725-1-11$ & 32.75 & 7.60 & 12.24 & 46.04 & & 98.63 & 13.03 & 20.64 & \\
\hline Fukadani $i^{-1-12}$ & 31.52 & 8.21 & 11.87 & 45.74 & & 97.34 & 14.07 & 20.02 & \\
\hline $50122801-1-1-a$ & 33.89 & 14.79 & 10.27 & 34.58 & 8.07 & 101.60 & 25.55 & 17.45 & \\
\hline$-1-3-a$ & 34.08 & 10.46 & 14.02 & 37.22 & 5.09 & 100.87 & 18.03 & 23.77 & 品 \\
\hline -1-3-b & 34.10 & 10.62 & 13.84 & 36.93 & 4.92 & 100.41 & 18.41 & 23.60 & \\
\hline$\frac{\text { Fukumaki }}{571118-1-a}$ & 34. & & & 5809 & & & & & \\
\hline$-1-b$ & $\begin{array}{l}34.11 \\
34.28\end{array}$ & 7.61 & $\begin{array}{l}1.98 \\
1.94\end{array}$ & 58.09 & & 101.60 & $\begin{array}{l}12.76 \\
13.08\end{array}$ & 3.34 & פְס \\
\hline $571148-1-a$ & $\begin{array}{l}33.05 \\
33.05\end{array}$ & 8.07 & 2.50 & $\begin{array}{l}55.97 \\
55.90\end{array}$ & & $\begin{array}{r}101.59 \\
99.59\end{array}$ & $\begin{array}{l}14.01 \\
14.01\end{array}$ & 4.28 & $=$ \\
\hline$-1-b$ & 33.06 & 7.19 & 2.68 & 56.77 & & 99.70 & 12.49 & 4.59 & \\
\hline$-2-a$ & 33.34 & 8.54 & 2.53 & 56.82 & & 101.23 & 14.53 & 4.24 & \\
\hline $5711503-3-a$ & 34.03 & 10.37 & 8.38 & 47.57 & & 100.35 & 17.70 & 14.06 & \\
\hline$-3-b$ & 34.22 & 10.43 & 8.61 & 47.07 & & 100.33 & 17.84 & 14.49 & \\
\hline$\frac{\mathrm{usug} 1}{58052607-1-\mathrm{a}}$ & & & & & & & & & \\
\hline $\begin{array}{l}38052000-1-\mathrm{d} \\
-1-\mathrm{s}\end{array}$ & $\begin{array}{l}34.51 \\
34.36\end{array}$ & $\begin{array}{l}8.36 \\
9.36\end{array}$ & $\begin{array}{l}12.10 \\
12.77\end{array}$ & $\begin{array}{l}45.09 \\
43.85\end{array}$ & & $\begin{array}{l}100.06 \\
100.34\end{array}$ & $\begin{array}{l}14.38 \\
15.93\end{array}$ & $\begin{array}{l}20.46 \\
21.38\end{array}$ & \\
\hline$-1-c$ & 34.32 & 9.50 & 12.74 & 42.73 & & 99.29 & 16.40 & 21.63 & \\
\hline$-2-a$ & 34.73 & 9.35 & 13.06 & 43.18 & & 100.32 & 15.98 & 21.97 & \\
\hline$-2-b$ & 34.68 & 9.83 & 13.42 & 42.74 & & 100.67 & 16.67 & 22.40 & \\
\hline
\end{tabular}




\begin{tabular}{|c|c|c|c|c|c|c|c|c|}
\hline \multirow{2}{*}{ B. } & \multicolumn{6}{|c|}{ wt. 8} & \multicolumn{2}{|c|}{$\mathrm{mol} . \mathrm{z}$} \\
\hline & $\mathrm{s}$ & Mn & $\mathrm{Fe}$ & $\mathrm{zn}$ & $\mathrm{cd}$ & Total & MnS & $\mathrm{FeS}$ \\
\hline$-3-a$ & 34.49 & 9.48 & 13.39 & 42.84 & & 100.20 & 16.16 & 22.45 \\
\hline $58052602-$ & 34.34 & & 13.58 & & & & & \\
\hline $\begin{array}{l}58052602- \\
58052601\end{array}$ & 34.63 & 9.70 & 13.51 & 42.99 & & 100.83 & 16.40 & 22.48 \\
\hline $58052601-$ & 33.96 & 7.83 & 11.76 & 44.92 & & 98.47 & 13.70 & 20.25 \\
\hline & 33.66 & 8.01 & 11.71 & 44.82 & & 98.2 & 14.01 & 20.14 \\
\hline Tsutsumi & 34.11 & 8.26 & 11.91 & 44.40 & & 98.68 & 14.43 & 20.45 \\
\hline $58052004-1-1-a$ & 33.62 & & & 54.93 & & 101.11 & & \\
\hline$-1-2-a$ & 33.90 & 7.89 & 4.78 & 54.83 & & & 13.45 & 8.02 \\
\hline$-1-2-b$ & 34.17 & 8.43 & 4.70 & 54.85 & & 102.15 & 14.25 & 7.81 \\
\hline$-1-3-a$ & 34.14 & 8.77 & 5.62 & 54.18 & & 102.71 & 14.66 & 9.24 \\
\hline 58052015-1-a & 34.45 & 8.26 & 10.88 & 47.10 & & 100. & 14.11 & 18.28 \\
\hline$-2-a$ & 33.85 & 9.06 & 9.37 & 47.85 & & 100.13 & 15.50 & 15.76 \\
\hline$-3-a$ & 34.25 & 8.87 & 10.13 & 47.34 & & 100.59 & 15.13 & 17.00 \\
\hline
\end{tabular}

c. Jacobsite analyses

\begin{tabular}{|c|c|c|c|c|c|c|c|c|}
\hline \multirow{2}{*}{ Hamayokogawa } & \\
\hline & MnO & $\mathrm{Mn}_{2} \mathrm{O}_{3}$ & $\mathrm{FeO}$ & $\mathrm{Fe}_{2} \mathrm{O}_{3}$ & $\mathrm{MgO}$ & $\mathrm{Al}_{2}{ }_{3}{ }_{3}$ & $\mathrm{TiO}_{2}$ & Total \\
\hline$-5208-2-1-A$ & 33.13 & 1.47 & 0.00 & 59.12 & 0.09 & 7.76 & 0.54 & 102.11 \\
\hline$-2-1-B$ & 32.91 & 1.86 & 0.00 & 60.37 & 0.14 & 6.66 & 0.49 & 102.43 \\
\hline$-2-3-A$ & 32.06 & 1.86 & 0.00 & 56.53 & 0.23 & 7.83 & 0.61 & 99.12 \\
\hline $5205-1-2-A$ & 31.40 & 1.29 & 0.00 & 63.58 & 0.13 & 3.44 & 0.23 & 100.07 \\
\hline$-1-2-B$ & 31.27 & 1.58 & 0.00 & 62.84 & 0.07 & 3.49 & 0.19 & 99.44 \\
\hline & 32.43 & 1.82 & 0.00 & 58.24 & 0.05 & 7.84 & 0.21 & 100.59 \\
\hline$-1-3-B$ & 31.26 & 2.61 & 0.00 & 63.83 & 0.05 & 2.01 & 0.23 & 99.99 \\
\hline$-1-3-c$ & 31.43 & 2.12 & 0.00 & 63.35 & 0.05 & 3.10 & 0.15 & 100.20 \\
\hline $\begin{array}{c}-1-4-\mathrm{A} \\
\text { Nodatamagawa }\end{array}$ & 31.69 & 2.53 & 0.00 & 60.97 & 0.07 & 4.59 & 0.22 & 100.07 \\
\hline$\frac{112-1-1-A}{A}$ & 14.41 & 0.00 & 16.47 & 65.59 & 0.43 & 2.90 & & 99.96 \\
\hline$-1-1-B$ & 15.18 & 0.00 & 15.54 & 64.99 & 0.48 & 3.06 & $\begin{array}{l}0.16 \\
0.21\end{array}$ & 99.46 \\
\hline$-1-2-B$ & 15.43 & 0.00 & 15.53 & 65.21 & 0.50 & 3.31 & 0.21 & 100.19 \\
\hline$-1-3-B$ & 10.96 & 0.00 & 18.97 & 67.55 & 0.20 & 0.06 & 0.00 & 97.74 \\
\hline$-2-1-A$ & 7.05 & 0.00 & 24.10 & 69.55 & 0.05 & 0.04 & 0.02 & 100.81 \\
\hline$-2-2-\mathrm{A}$ & 13.39 & 0.00 & 16.22 & 66.41 & 0.79 & 1.59 & 0.11 & 98.51 \\
\hline $\begin{array}{l}-2-3-A \\
-2-3-B\end{array}$ & 24.90 & 0.00 & 4.90 & 63.47 & 0.94 & 3.86 & 0.29 & 98.36 \\
\hline Kaso $^{-2-3-B}$ & 25.40 & 0.00 & 4.60 & 64.03 & 0.66 & 3.10 & & 98.08 \\
\hline $28-1-A$ & 40.38 & 0.72 & & 42.07 & & & & 99.53 \\
\hline$-2-\mathrm{A}$ & $\begin{array}{l}35.39 \\
35.30\end{array}$ & $\begin{array}{l}1.41 \\
1.41\end{array}$ & 0.00 & 50.31 & 0.50 & 8.76 & 4.05 & 100.42 \\
\hline$-2-B$ & 37.80 & 0.80 & 0.00 & 47.65 & 0.55 & $\begin{array}{l}6.84 \\
6.84\end{array}$ & 7.03 & 100.67 \\
\hline$-2-\mathrm{C}$ & 35.09 & 0.92 & 0.00 & 51.42 & 0.37 & 9.41 & 3.35 & 100.56 \\
\hline$-3-\mathrm{A}$ & 33.74 & 1.52 & 0.00 & 52.58 & 0.68 & 10.82 & 1.90 & 101.24 \\
\hline$-3-B$ & 32.81 & 2.06 & 0.00 & 53.96 & 0.58 & 8.45 & 1.72 & 99.58 \\
\hline $29-2-1-A$ & 34.78 & 2.03 & 0.00 & 50.27 & 1.76 & 5.18 & 5.99 & 100.01 \\
\hline$-2-1-B$ & 32.65 & 1.26 & 0.00 & 53.22 & 1.45 & 10.17 & 2.17 & 100.92 \\
\hline$-2-1-c$ & 34.93 & 1.90 & 0.00 & 49.73 & 1.83 & 4.63 & 6.76 & 99.78 \\
\hline$-2-2-A$ & 36.57 & 1.97 & 0.00 & 50.13 & 1.18 & 5.62 & 6.52 & 101.99 \\
\hline$-2-2-B$ & 33.98 & 0.30 & 0.00 & 52.79 & 1.10 & 9.37 & 3.25 & 100.79 \\
\hline$-2-3-A$ & 39.54 & 0.11 & 0.00 & 43.37 & 0.94 & 5.62 & 10.12 & 99.70 \\
\hline $22-B-2-4-A$ & 35.67 & 0.00 & 4.71 & 44.44 & 0.07 & 5.59 & 9.48 & 99.96 \\
\hline$-2-4-B$ & 37.50 & 0.00 & 5.39 & 39.88 & 0.11 & 3.79 & 12.76 & 99.43 \\
\hline$-2-4-C$ & 33.89 & 0.00 & 4.71 & 48.42 & 0.07 & 6.17 & 7.26 & 100.52 \\
\hline & 34.35 & & & & 0.04 & 6.90 & 7.59 & 100.01 \\
\hline
\end{tabular}

A-11
D. Rhodonite analyses

\begin{tabular}{|c|c|c|c|c|c|c|c|c|}
\hline \multirow{2}{*}{ Hagidaira } & \multicolumn{7}{|c|}{ wt. 8} & \multirow[b]{2}{*}{ Total } \\
\hline & MnO & FeO & MgO & $\mathrm{CaO}$ & $\mathrm{SiO}_{2}$ & $\mathrm{Al}_{2} \mathrm{O}_{3}$ & $\mathrm{TiO}_{2}$ & \\
\hline$\frac{570719-4-3}{570}$ & 45.44 & 0.22 & 2.08 & 6.99 & 47.15 & 0.01 & 0.00 & 101.89 \\
\hline$-4-4$ & 44.98 & 0.19 & 2.08 & 6.84 & 47.04 & 0.01 & 0.01 & 101.15 \\
\hline$-5-3$ & 47.09 & 0.10 & 1.26 & 5.04 & 46.68 & 0.01 & 0.01 & 100.19 \\
\hline$-5-6$ & 47.26 & 0.09 & 1.14 & 5.23 & 46.43 & 0.02 & 0.01 & 100.18 \\
\hline & 47.69 & 0.14 & 1.31 & 4.58 & 45. 31 & 0.01 & 0.00 & 99.04 \\
\hline $570720-1-2$ & 42.53 & 0.19 & 3.40 & 7.08 & 47.80 & 0.01 & 0.00 & 101.01 \\
\hline $570724-1-2$ & 52.32 & 0.15 & 0.50 & 2.57 & 43.59 & 0.00 & 0.01 & 99.14 \\
\hline$-1-5$ & 52.38 & 0.15 & 0.44 & 2.79 & 44.12 & 0.00 & 0.00 & 99.88 \\
\hline$-3-2$ & 54.08 & 0.19 & 0.43 & 1.67 & 43.20 & 0.01 & 0.00 & 99.58 \\
\hline$-3-4$ & 53.62 & 0.27 & 0.44 & 1.71 & 42.55 & 0.00 & 0.00 & $\begin{array}{l}98.59 \\
09\end{array}$ \\
\hline & 52.76 & 0.19 & 0.54 & 2.72 & 43.08 & 0.02 & 0.01 & 99.32 \\
\hline $570716-1-2$ & 49.18 & 0.31 & 0.33 & 4.72 & 45.90 & 0.01 & 0.00 & 100.45 \\
\hline & 49.35 & 0.52 & 0.19 & 4.26 & 46.27 & 0.02 & 0.00 & 100.61 \\
\hline$-2-1$ & 47.70 & 0.07 & 0.85 & 5.48 & 46.18 & 0.00 & 0.00 & 100.28 \\
\hline $\begin{array}{l}-2-2 \\
-2-4\end{array}$ & $\begin{array}{l}47.50 \\
48.42\end{array}$ & 0.20 & 0.73 & $\begin{array}{l}6.20 \\
5.60\end{array}$ & $\begin{array}{l}45.90 \\
46.12\end{array}$ & $\begin{array}{l}0.01 \\
0.01\end{array}$ & 0.00 & $\begin{array}{l}100.54 \\
100.99\end{array}$ \\
\hline $\begin{array}{l}-2-4 \\
-2-7\end{array}$ & $\begin{array}{l}48.42 \\
48.43\end{array}$ & 0.17 & $\begin{array}{l}0.66 \\
0.69\end{array}$ & $\begin{array}{l}5.60 \\
5.49\end{array}$ & $\begin{array}{l}46.12 \\
46.41\end{array}$ & $\begin{array}{l}0.01 \\
0.01\end{array}$ & $\begin{array}{l}0.01 \\
0.00\end{array}$ & $\begin{array}{l}100.99 \\
101.21\end{array}$ \\
\hline & $\begin{array}{l}48.43 \\
50.63\end{array}$ & 0.18 & $\begin{array}{l}0.69 \\
0.65\end{array}$ & $\begin{array}{l}3.49 \\
3.45\end{array}$ & $\begin{array}{l}46.41 \\
45.75\end{array}$ & $\begin{array}{l}0.01 \\
0.01\end{array}$ & 0.00 & $\begin{array}{l}101.21 \\
100.67\end{array}$ \\
\hline$-3-4$ & $\begin{array}{l}50.63 \\
50.49\end{array}$ & 0.17 & 0.59 & 4.34 & 46.14 & $\begin{array}{l}0.02 \\
0.02\end{array}$ & $\begin{array}{l}0.00 \\
0.00\end{array}$ & $\begin{array}{l}101.75 \\
101.75\end{array}$ \\
\hline$-3-6$ & 48.70 & 0.13 & 0.50 & 5.60 & 46.60 & 0.02 & 0.01 & 101.56 \\
\hline $570721-1-2$ & 44.08 & 4.41 & 0.93 & 4.49 & 47.24 & 0.00 & 0.01 & 101.16 \\
\hline & 46.32 & 4.00 & 0.71 & 4.19 & 45.98 & 0.01 & 0.00 & 101.21 \\
\hline$-2-3$ & 46.27 & 2.88 & 0.59 & 4.70 & 46.20 & 0.00 & 0.01 & 100.65 \\
\hline$-2-4$ & 45.46 & 2.98 & 0.69 & 5.19 & 47.21 & 0.00 & 0.01 & 101.54 \\
\hline$-3-2$ & 47.28 & 2.93 & 0.61 & 4.72 & 45.99 & 0.00 & 0.00 & 101.53 \\
\hline$-3-3$ & 45.76 & 3.53 & 0.68 & 4.65 & 46.48 & 0.02 & 0.01 & 101.13 \\
\hline $570725-1-2$ & 48.58 & 0.44 & 1.69 & 3.63 & 44.06 & 0.01 & 0.00 & 98.41 \\
\hline$-2-1$ & 48.83 & 1.02 & 1.62 & 3.34 & 44.34 & 0.01 & 0.00 & 99.16 \\
\hline$-2-3$ & 49.21 & 0.61 & 1.87 & 3.05 & 45.22 & 0.00 & 0.00 & 99.96 \\
\hline Fukumaki $i^{-3-3}$ & 48.42 & 0.42 & 1.53 & 4.44 & 44.76 & 0.01 & 0.00 & 99.58 \\
\hline 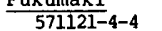 & 45.05 & & & & 44.53 & & & \\
\hline & 45.56 & 0.12 & 0.70 & 7.91 & 43.71 & & & 98.02 \\
\hline $571145-2-2$ & 49.73 & 0.13 & 0.52 & 4.11 & 46.02 & 0.79 & 0.00 & 101.30 \\
\hline$-2-3$ & 51.04 & 0.19 & 0.59 & 2.99 & 45.29 & 0.98 & 0.00 & 101.08 \\
\hline$-2-4$ & 50.43 & 0.22 & 0.45 & 3.44 & 45.02 & 0.49 & 0.00 & 100.05 \\
\hline$-2-5$ & 50.15 & 0.24 & 0.45 & 3.88 & 45.03 & 0.82 & 0.00 & 100.57 \\
\hline $5711515-2-3$ & 47.72 & 0.71 & 2.12 & 3.73 & 47.11 & 0.01 & 0.00 & 101.40 \\
\hline$-3-2$ & 47.56 & 0.70 & 2.03 & 4.22 & 46.40 & 0.00 & 0.02 & 100.93 \\
\hline $11503-1-1$ & 50.86 & 1.44 & 0.52 & 2.45 & 46.11 & 0.01 & 0.01 & 101.40 \\
\hline & 50.60 & 1.67 & 0.54 & 2.47 & 45. & 0.01 & 0.02 & 101.29 \\
\hline-2 & 50.17 & 1.93 & 0. & 2.56 & 46.76 & 0.00 & 0.01 & 101.97 \\
\hline & 50.75 & 1.21 & 0.51 & 2 . & 46. & 0.02 & 0.01 & 101.84 \\
\hline & 50.91 & 1.14 & 0.51 & 2.66 & 46. & 0.04 & 0.01 & 101.87 \\
\hline & 51.09 & 1.05 & 0.52 & 2. & 46. & 0.00 & 0.00 & 101.77 \\
\hline & 49. & 1.15 & 0.52 & & & 0.02 & 0.01 & \\
\hline $9-1-1$ & 50. & 1.13 & 0. & 2. & 46.12 & 0.01 & 0.03 & 101.02 \\
\hline$-1-2$ & 50.18 & 1.21 & 0.54 & & 46. & 0.02 & 0.01 & 100.70 \\
\hline$-2-2$ & 50.48 & 1.05 & 0.51 & 2.09 & 44.67 & 0.01 & 0.01 & 98.82 \\
\hline$-2-3$ & 50.40 & 1.04 & 0.54 & 2.81 & 45.77 & 0.02 & 0.01 & 100.59 \\
\hline & 51.51 & 1.11 & 0.55 & 2.13 & 46.12 & 0.01 & 0.00 & 101.43 \\
\hline $58052607-1-1$ & 50.04 & 2.90 & 1.57 & 0.97 & 42.87 & 0.01 & 0.01 & 98.37 \\
\hline
\end{tabular}


D. (continued)

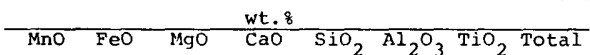
$\begin{array}{lllllllll}-1-2 & 47.82 & 2.74 & 1.55 & 3.17 & 44.18 & 0.01 & 0.00 & 99.47\end{array}$ $\begin{array}{lllllllll}-2-1 & 50.59 & 2.49 & 1.95 & 0.38 & 43.03 & 0.02 & 0.00 & 98.51 \\ -2-2 & 48.99 & 3.50 & 1.97 & 0.38 & 44.58 & 0.01 & 0.01 & 99.44\end{array}$ $\begin{array}{llllllllll}-2-3 & 49.10 & 2.79 & 2.40 & 0.57 & 43.63 & 0.01 & 0.01 & 98.51 \\ -3-1 & 50.53 & 2.24 & 1.50 & 1.26 & 44.44 & 0.01 & 0.01 & 99.99\end{array}$

E. Pyroxmangite analyses

\begin{tabular}{|c|c|c|c|c|c|c|c|c|}
\hline \multirow[b]{2}{*}{$\mathrm{kad}$} & \multicolumn{7}{|c|}{ wt. 8} & \multirow[b]{2}{*}{ Total } \\
\hline & MnO & FeO & MgO & $\mathrm{CaO}$ & $\mathrm{SiO}_{2}$ & $\mathrm{A1}_{2} \mathrm{O}$ & $\mathrm{TiO}_{2}$ & \\
\hline $301-1-1$ & 45.85 & 3.62 & 3.20 & 1.78 & 47.03 & 0.01 & 0.00 & 101.49 \\
\hline & & 4.26 & & & & & 0.01 & \\
\hline & & 3.52 & & 1.36 & & & 0.00 & \\
\hline & & 4.09 & & & & & 0.01 & 101.35 \\
\hline & & 8.16 & & 1.73 & & & 0.00 & \\
\hline & 9 & 4.69 & 3.41 & & 46.3 & 0. & 0.00 & 100.46 \\
\hline \multicolumn{8}{|l|}{ Tsutsumi } & \\
\hline $58052015-2-1$ & & & & & & & & \\
\hline & & & & & & & 0. & \\
\hline & & & 4. & & & & 0.00 & \\
\hline & & 0.7 & 4.6 & & 46. & & $0 . c_{0}$ & 100 \\
\hline & & 0.7 & 3.5 & & 45. & & 0.00 & 100 \\
\hline & & & 4. & & & & 0. & 101.12 \\
\hline & 48.90 & 0.75 & 4.63 & 0.37 & 46.32 & 0.02 & 0.00 & 100.99 \\
\hline
\end{tabular}

F. Tephroite analyses

\begin{tabular}{|c|c|c|c|c|c|c|c|c|}
\hline \multirow[b]{2}{*}{ shōwa } & \multicolumn{7}{|c|}{ wt. 8} & \multirow[b]{2}{*}{ Total } \\
\hline & MnO & $\mathrm{FeO}$ & $\mathrm{MgO}$ & $\mathrm{CaO}$ & $\mathrm{SiO}_{2}$ & $\mathrm{Al}_{2} \mathrm{O}_{3}$ & $\mathrm{TiO}_{2}$ & \\
\hline 570709-2-5 & 66.63 & 4.74 & 0.74 & 0.01 & 27.94 & 0.00 & 0.07 & 100.13 \\
\hline$-3-2$ & 66.58 & 4.26 & 0.74 & 0.02 & 27.00 & 0.00 & 0.32 & 98.92 \\
\hline & 66.77 & 3.48 & 0.89 & 0.03 & 27.80 & 0.01 & 0.08 & 99.06 \\
\hline Hagidaira & 65.77 & 4.79 & 0.74 & 0.04 & 27.13 & 0.01 & 0.38 & 98. \\
\hline $570728-3-2$ & 67.20 & & & 0.10 & 28.90 & 0.01 & 0.02 & 99.64 \\
\hline & 67.13 & 0.39 & 2.97 & & & & & \\
\hline & 67.28 & 0.36 & 3.05 & 0.08 & 28.91 & & 0.00 & 99.69 \\
\hline $570730-1-1$ & 67.13 & 0.41 & 3.06 & 0.11 & 28.08 & & 0.01 & 98.80 \\
\hline & 67.15 & 0.42 & 3.03 & & 28.40 & & 0. & \\
\hline & .42 & 0.39 & 3.06 & & 28.23 & & 0. & \\
\hline & 67.85 & 0.37 & 3.03 & & 28. & & 0.03 & \\
\hline & 66.88 & 0.42 & 3.06 & & 28. & & 0.02 & \\
\hline-2 & 66.94 & 0.41 & 3.11 & & & & 0.02 & \\
\hline & & 0.44 & 3.00 & & & & & 99.14 \\
\hline & 67.46 & 0.4 & 3.15 & & & & 0.00 & \\
\hline & 67. & 0.4 & 2.5 & & 27. & & 0.00 & \\
\hline & 67.8 & 0. & 2.9 & & 28.04 & 0. & 0.01 & 99. \\
\hline & 67.40 & 0.43 & 3.10 & 0.09 & 28.48 & 0.01 & 0.02 & 99.53 \\
\hline
\end{tabular}

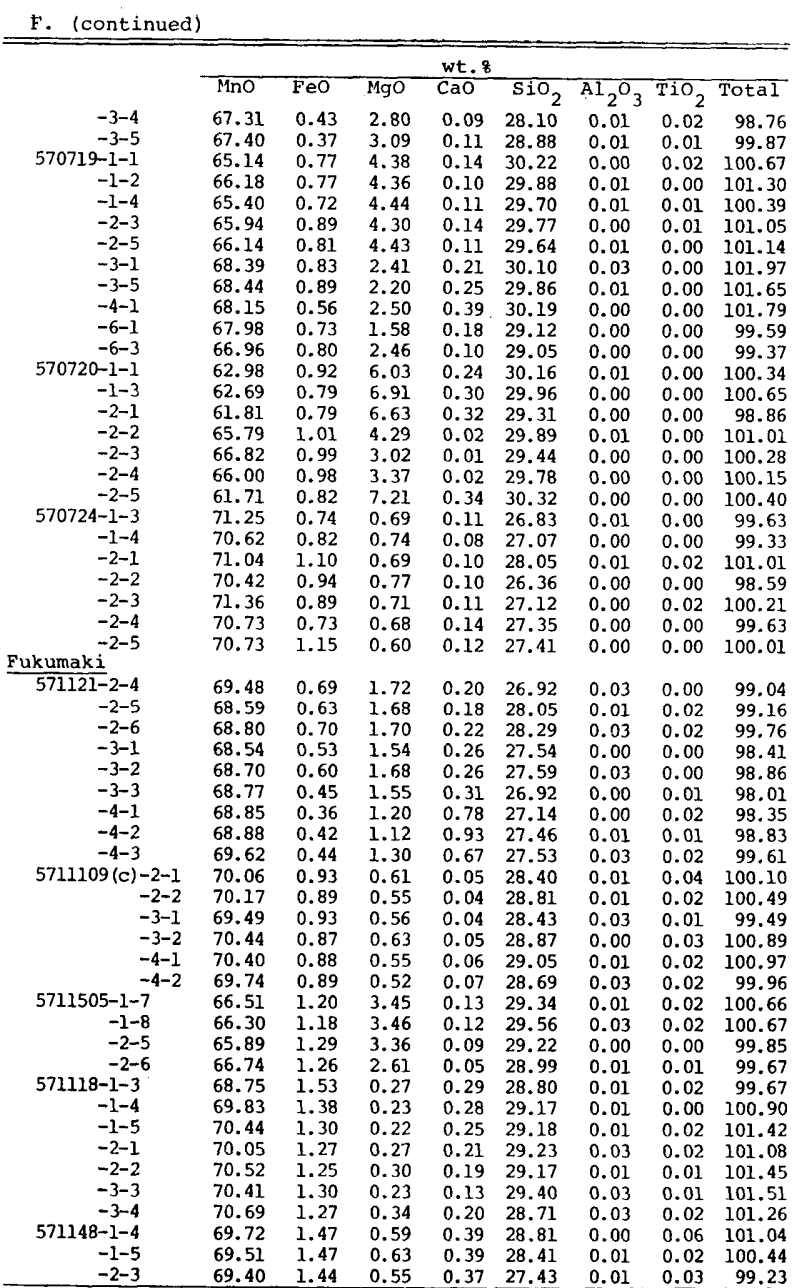

A-14 
F. (continued)

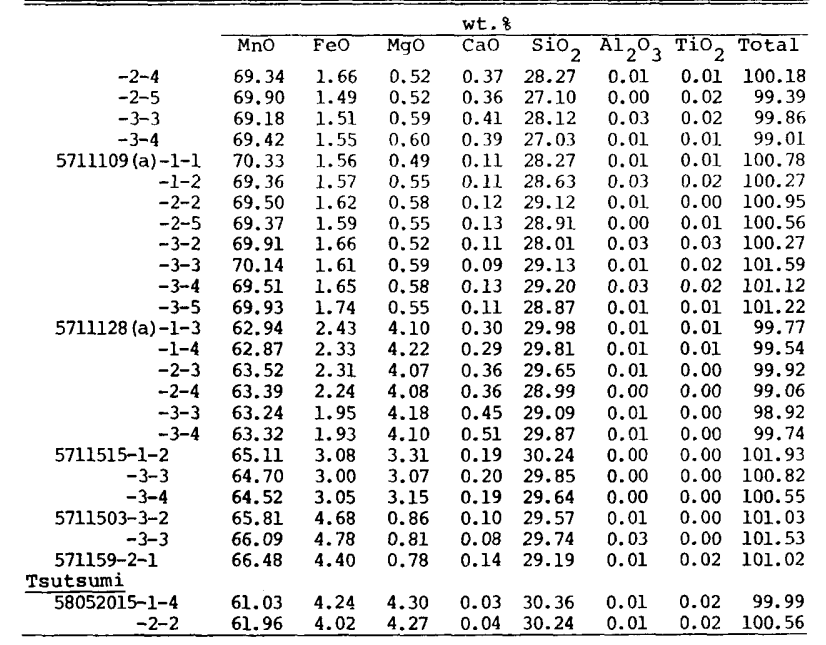

G. Alleghanyite analyses

\begin{tabular}{rllllllll}
\hline & \multicolumn{10}{c}{ wt.8 } \\
\cline { 2 - 10 } Hanawa & MnO & FeO & MgO & CaO & $\mathrm{SIO}_{2}$ & $\mathrm{Al}_{2} \mathrm{O}_{3}$ & $\mathrm{TiO}_{2}$ TOtal \\
\hline $570733-1-1$ & 66.47 & 0.22 & 4.03 & 0.03 & 23.06 & 0.02 & 0.08 & 93.91 \\
$-1-2$ & 65.97 & 0.22 & 3.95 & 0.02 & 23.27 & 0.01 & 0.04 & 93.48 \\
$-1-4$ & 65.88 & 0.21 & 4.22 & 0.02 & 23.59 & 0.13 & 0.16 & 94.21 \\
$-2-1$ & 65.06 & 0.23 & 4.96 & 0.03 & 23.98 & 0.01 & 0.15 & 94.42 \\
$-2-4$ & 65.35 & 0.24 & 4.76 & 0.02 & 24.07 & 0.00 & 0.06 & 94.50 \\
$-2-5$ & 65.58 & 0.23 & 5.29 & 0.02 & 23.72 & 0.03 & 0.02 & 94.88 \\
$-3-1$ & 66.42 & 0.22 & 4.45 & 0.02 & 23.72 & 0.01 & 0.13 & 94.97 \\
$-3-2$ & 65.97 & 0.18 & 4.32 & 0.01 & 24.12 & 0.03 & 0.12 & 94.75 \\
$-3-4$ & 66.91 & 0.25 & 4.40 & 0.03 & 23.71 & 0.01 & 0.07 & 95.38 \\
$-4-2$ & 66.15 & 0.20 & 4.47 & 0.02 & 23.87 & 0.05 & 0.06 & 94.82 \\
$-4-4$ & 64.85 & 0.26 & 4.64 & 0.01 & 23.69 & 0.00 & 0.15 & 93.60 \\
Showa & & & & & & & & \\
\hline $570708-1-2$ & 69.33 & 0.11 & 1.08 & 0.03 & 23.24 & 0.03 & 0.15 & 93.97 \\
$-2-2$ & 69.06 & 0.14 & 1.31 & 0.05 & 22.54 & 0.01 & 0.10 & 93.21 \\
$-3-4$ & 68.89 & 0.16 & 1.49 & 0.05 & 22.58 & 0.01 & 0.15 & 93.33 \\
$570706-1-1$ & 69.01 & 0.10 & 2.31 & 0.04 & 23.85 & 0.00 & 0.15 & 95.46 \\
$-1-2$ & 68.46 & 0.16 & 2.28 & 0.04 & 23.33 & 0.00 & 0.08 & 94.35 \\
$-1-3$ & 68.15 & 0.16 & 2.81 & 0.04 & 23.73 & 0.01 & 0.04 & 94.94 \\
$-2-1$ & 69.01 & 0.15 & 2.13 & 0.02 & 23.34 & 0.00 & 0.06 & 94.71 \\
$-2-2$ & 67.72 & 0.14 & 3.28 & 0.03 & 24.08 & 0.01 & 0.03 & 95.29 \\
$-2-3$ & 68.75 & 0.18 & 2.45 & 0.00 & 23.53 & 0.00 & 0.02 & 94.93 \\
\hline
\end{tabular}

A-15

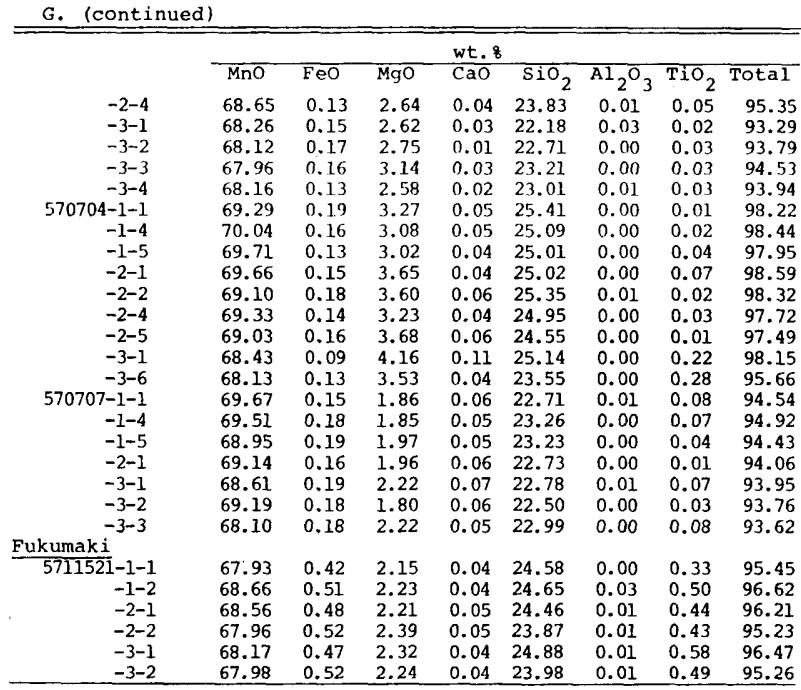

H. Sonolite analyses

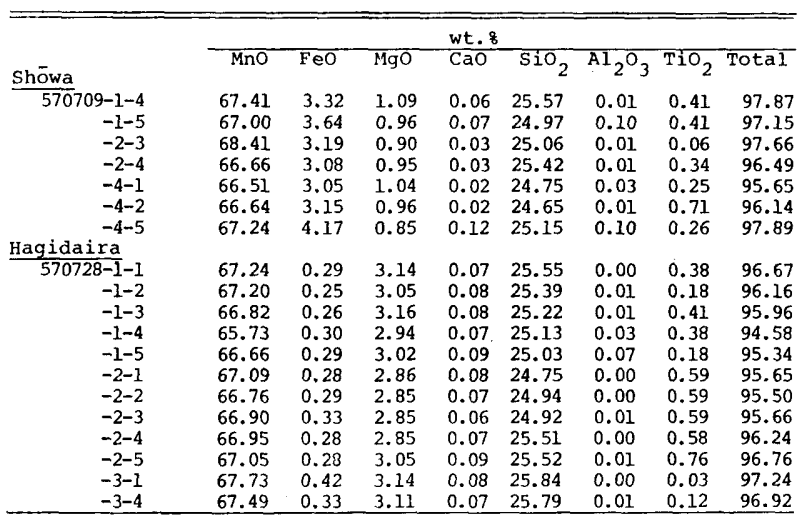

A-16 


\begin{tabular}{|c|c|c|c|c|c|c|c|c|}
\hline \\
\hline & MnO & FeO & MgO & $\mathrm{CaO}$ & $\mathrm{SiO}_{2}$ & $\mathrm{Al}_{2} \mathrm{O}_{3}$ & $\mathrm{TiO}_{2}$ & Total \\
\hline $570719-1-3$ & 65.78 & 0.61 & 4.57 & 0.08 & 27.08 & 0.03 & 0.19 & 98.34 \\
\hline & & & & & & & 0.10 & \\
\hline & & & 4.3 & & & & 0.13 & $\begin{array}{l}98.83 \\
97.50\end{array}$ \\
\hline & 7 & 0.56 & 3.01 & & & & 0.00 & 97. \\
\hline & .85 & 0.51 & 2.8 & .15 & & & 0.00 & 97.59 \\
\hline & & 0. & 1. & & & & 0.00 & 96. \\
\hline & & 0.49 & 3.14 & 15 & & 0.00 & 0.00 & 97.04 \\
\hline & 9 & 0.53 & 3.39 & & & 0.00 & 0.00 & 96.81 \\
\hline $570720-1-4$ & .94 & 0.61 & 10.50 & .12 & 7.49 & 0.00 & 0.61 & 97.27 \\
\hline Fukumaki $^{-1-5}$ & 57.71 & 0.63 & 9.83 & 42 & .52 & 0.00 & 0.96 & \\
\hline$\frac{\text { Fukumaki }}{5711516-1-1}$ & 68.88 & 0.15 & 1.68 & 0.05 & 25.14 & 0.01 & & \\
\hline & & & $\begin{array}{l}1.08 \\
1.71\end{array}$ & & & & & \\
\hline$-1-3$ & 9.83 & 0.21 & $\begin{array}{l}1.72 \\
1.72\end{array}$ & .06 & 75 & $\begin{array}{l}0.01 \\
0.01\end{array}$ & $\begin{array}{l}0.31 \\
0.32\end{array}$ & \\
\hline$-2-2$ & & & $\begin{array}{l}1.68 \\
1.68\end{array}$ & & 25. & $\begin{array}{l}0.00 \\
0.00\end{array}$ & 0.07 & \\
\hline$-2-3$ & & & 1. & & 25. & 0.00 & & \\
\hline$-3-2$ & & & & & & & & \\
\hline $571121-1-1$ & & & & & & & & \\
\hline$-1-2$ & & & & & & 0.01 & & \\
\hline$-1-3$ & & $0.4>>$ & 2. & & & 0.01 & & \\
\hline$-1-4$ & & & & & & 0.01 & & \\
\hline$-2-1$ & & & & & & & & \\
\hline$-2-2$ & & 0.5 & & & & & & \\
\hline$-2-3$ & & & & & & 0.01 & & \\
\hline 571193-1-1 & & & 2. & & & 0.01 & & \\
\hline & & & 2.7 & & & 0.03 & & 96. \\
\hline$-1-$ & & & & & & 0.01 & & \\
\hline & & & & & & 0.0 & & \\
\hline$-1-5$ & & & & & & 0.0 & & \\
\hline 571145-1-1 & & & & & & 0.0 & & \\
\hline & & & 3. & & & 0.0 & & 97.35 \\
\hline & & & 3. & & & & & \\
\hline & & 0. & 3.1 & & & & & \\
\hline $\begin{array}{l}-1-5 \\
-2-1\end{array}$ & & 0.5 & 3.1 & 0.06 & & 0.00 & & \\
\hline${ }^{-2-1}$ & & 0.5 & 3.5 & 0.06 & 25. & 0.00 & & 7.37 \\
\hline 5711109 (c) $-1-1-1$ & & 0.6 & 0.6 & 0.07 & 25. & 0.03 & & 96.98 \\
\hline & & & 0.5 & 0.06 & & & & 96.94 \\
\hline & & & & 0.1 & & & & 98.14 \\
\hline & & 0. & $\begin{array}{l}4.60 \\
4.45\end{array}$ & $\begin{array}{l}0.13 \\
0.12\end{array}$ & & $\begin{array}{l}0.00 \\
0.00\end{array}$ & $\begin{array}{l}1.01 \\
1.22\end{array}$ & $\begin{array}{l}98.39 \\
97.74\end{array}$ \\
\hline & & 0.8 & $4.4 \quad \longrightarrow$ & 0.11 & 26. & 0.00 & 1. & 97.40 \\
\hline$-2-$ & & 0. & & & & & & 98.39 \\
\hline$-2-8$ & 64.91 & 0.88 & 4.63 & 0.09 & 26,73 & 0.00 & 0.74 & 97.98 \\
\hline
\end{tabular}

I. Rhodochrosite analyses

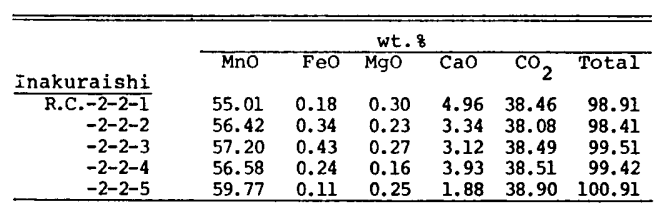

I. (continued)

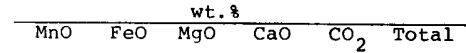

$\begin{array}{llllllr}-2-3-1 & 60.43 & 0.44 & 0.36 & 0.64 & 38.66 & 100.53 \\ -2-3-2 & 60.03 & 0.45 & 0.39 & 0.62 & 38.43 & 99.92\end{array}$

$\begin{array}{llllllll}-2-3-3 & 59.35 & 0.48 & 0.38 & 0.68 & 38.43 & 99.92 \\ -2-3-4 & 61.01 & 0.17 & 0.32 & 0.51 & 38.22 & 90.31\end{array}$

$-2-3-5$

$\begin{array}{rrrrrr}59.35 & 0.48 & 0.38 & 0.88 & 38.22 & 99.31 \\ 61.01 & 0.17 & 0.32 & 0.50 & 38.70 & 100.70 \\ 60.57 & 0.31 & 0.43 & 0.87 & 38.92 & 101.10\end{array}$

\begin{tabular}{rlllllll}
\hline $570733-3-5$ & 58.78 & 0.12 & 0.36 & 2.62 & 38.99 & 100.87 \\
$-4-5$ & 59.22 & 0.07 & 0.38 & 2.06 & 38.81 & 100.54
\end{tabular}

\begin{tabular}{clllllll} 
Shōwa $^{-4-5}$ & 59.22 & 0.07 & 0.38 & 2.06 & 38.81 & 100.54 \\
\hline $570708-1-1$ & 61.77 & 0.11 & 0.03 & 0.56 & 38.86 & 101.33
\end{tabular}

$\begin{array}{llllllr}-2-1 & 60.20 & 0.08 & 0.00 & 0.47 & 37.77 & 98.52 \\ -2-3 & 59.34 & 0.09 & 0.00 & 1.15 & 37.77 & 98.35 \\ -2-4 & 60.11 & 0.08 & 0.02 & 0.72 & 37.93 & 98.86\end{array}$

$\begin{array}{llllll}59.34 & 0.09 & 0.00 & 1.15 & 37.77 & 98.35 \\ 60.11 & 0.08 & 0.02 & 0.72 & 37.93 & 98.86 \\ 59.86 & 0.10 & 0.11 & 0.99 & 38.09 & 99.14\end{array}$

$\begin{array}{rrrrrrr}59.86 & 0.10 & 0.11 & 0.99 & 38.09 & 99.14 \\ 61.40 & 0.10 & 0.30 & 0.69 & 39.02 & 101.51\end{array}$

$\begin{array}{lllllll}59.35 & 0.12 & 0.39 & 0.91 & 38.03 & 98.80 \\ 59.37 & 0.09 & 0.31 & 1.40 & 38.33 & 99.50\end{array}$

$\begin{array}{lllllll}57.65 & 0.12 & 0.55 & 2.82 & 38.65 & 99.79\end{array}$

$\begin{array}{lllllll}62.05 & 0.13 & 0.05 & 0.03 & 38.65 & 100.91 \\ 55.23 & 0.11 & 0.39 & 5.80 & 39.31 & 100.84\end{array}$

$\begin{array}{lllllll}55.23 & 0.11 & 0.39 & 5.80 & 39.31 & 100.84 \\ 52.52 & 0.07 & 0.48 & 7.58 & 39.10 & 9.75\end{array}$

$\begin{array}{lllllll}61.56 & 0.10 & 0.00 & 0.48 & 38.63 & 100.77\end{array}$

$\begin{array}{llllll}61.74 & 0.10 & 0.03 & 0.00 & 38.40 & 10.27 \\ 61.97 & 0.13 & 0.14 & 0.19 & 38.83 & 101.26\end{array}$

$\begin{array}{lllllll}61.97 & 0.13 & 0.14 & 0.19 & 38.83 & 101.26 \\ 61.00 & 0.18 & 0.19 & 0.80 & 38.79 & 100.96\end{array}$

$\begin{array}{llllll}61.00 & 0.18 & 0.19 & 0.80 & 38.79 & 100.96 \\ 61.46 & 0.11 & 0.05 & 0.40 & 38.57 & 100.59\end{array}$

$\begin{array}{lllllll}59.07 & 0.14 & 0.28 & 2.57 & 39.06 & 101.12\end{array}$

$\begin{array}{llllll}61.89 & 0.18 & 0.24 & 0.23 & 38.95 & 101.49 \\ 57.49 & 0.81 & 0.58 & 3.08 & 39.21 & 101.17\end{array}$

$\begin{array}{rrrrrrr}57.49 & 0.81 & 0.58 & 3.08 & 39.21 & 101.17 \\ 56.15 & 0.59 & 0.55 & 3.45 & 38.51 & 99.25\end{array}$

$\begin{array}{rrrrrr}56.15 & 0.59 & 0.55 & 3.45 & 38.51 & 99.25 \\ 57.36 & 0.56 & 0.50 & 3.07 & 38.88 & 100.37\end{array}$

$\begin{array}{llllll}56.08 & 0.31 & 0.64 & 4.63 & 39.31 & 100.97 \\ 56.54 & 0.18 & 1.01 & 4.16 & 39.56 & 101.45\end{array}$

Hijikuzu

$\begin{array}{lllllll}60.88 & 0.09 & 0.00 & 0.76 & 38.42 & 100.15\end{array}$ $\begin{array}{lllllll}095-1-1-3 & 60.88 & 0.09 & 0.00 & 0.76 & 38.42 & 100.15 \\ -1-3-2 & 59.59 & 0.07 & 0.00 & 1.00 & 37.80 & 98.46 \\ -1-4-5 & 58.36 & 0.13 & 0.00 & 2.31 & 38.10 & 98.90\end{array}$

\begin{tabular}{crrrrrr} 
Hagidaira & 58.36 & 0.13 & 0.00 & 2.31 & 38.10 & 98.90 \\
\hline $570730-1-2$ & 33.50 & 0.06 & 1.22 & 24.18 & 41.13 & 100.09 \\
$-1-4$ & 32.39 & 0.07 & 1.45 & 25.00 & 41.34 & 100.25
\end{tabular}

$\begin{array}{rrrrrrr}570719-1-6 & 36.71 & 0.10 & 1.98 & 19.41 & 40.23 & 98.43 \\ 570720-3-1 & 52.23 & 0.16 & 4.70 & 2.22 & 39.38 & 98.69 \\ 570724-3-3 & 51.15 & 1.38 & 1.38 & 7.31 & 39.82 & 101.04\end{array}$

$\begin{array}{ccccccc}570720-3-1 & 52.23 & 0.16 & 4.38 & .22 & 49.38 & 98.69 \\ 570724-3-3 & 51.15 & 1.38 & 1.38 & 7.31 & 39.82 & 101.04 \\ 570716-1-4 & 53.75 & 0.29 & 0.85 & 5.68 & 38.91 & 99.48\end{array}$

$\begin{array}{lllllll}53.75 & 0.29 & 0.85 & 5.68 & 38.91 & 99.48 \\ 52.95 & 0.30 & 0.85 & 6.55 & 39.10 & 99.75\end{array}$

$\begin{array}{llllll}50.43 & 0.30 & 0.86 & 8.06 & 38.74 & 98.39\end{array}$

$\begin{array}{lllllll}50.69 & 0.25 & 0.86 & 8.74 & 39.40 & 99.94\end{array}$

$\begin{array}{rrrrrrr}52.61 & 0.31 & 0.29 & 8.31 & 39.67 & 101.19\end{array}$

$\begin{array}{rrrrrr}49.41 & 2.05 & 1.14 & 7.70 & 39.20 & 99.50\end{array}$

$\begin{array}{lllllll}48.47 & 2.16 & 1.09 & 8.37 & 39.15 & 99.24\end{array}$

$\begin{array}{lllllr}48.82 & 2.06 & 1.06 & 8.12 & 39.08 & 99.14 \\ 50.98 & 1.38 & 1.23 & 7.31 & 39.55 & 100.45\end{array}$

\begin{tabular}{rrrrrrr}
$-3-4$ & 50.98 & 1.38 & 1.23 & 7.31 & 39.55 & 100.45 \\
$-3-5$ & 54.77 & 1.17 & 1.09 & 4.95 & 39.77 & 101.75 \\
$570725-1-4$ & 50.44 & 2.60 & 1.82 & 6.37 & 39.87 & 101.10 \\
$-2-4$ & 57.57 & 1.14 & 0.16 & 3.24 & 39.13 & 101.24 \\
\hline
\end{tabular} 


\begin{tabular}{|c|c|c|c|c|c|c|}
\hline & \multicolumn{6}{|c|}{ wt. 8} \\
\hline & $\mathrm{MnO}$ & $\mathrm{FeO}$ & $\mathrm{MgO}$ & $\mathrm{CaO}$ & $\mathrm{CO}_{2}$ & Total \\
\hline $\operatorname{kadani} i^{-3-1}$ & 57.88 & 1.06 & 1.00 & 1.55 & 38.87 & 100.36 \\
\hline $\begin{array}{l}50122801-2-5 \\
\text { Fukumaki }\end{array}$ & 50.81 & 4.12 & 2.54 & 3.42 & 39.50 & 100.39 \\
\hline $5711516-2-1$ & 55.92 & 0.11 & 1.37 & 4.06 & 39.44 & 100.90 \\
\hline & 55.80 & 0.12 & 1.44 & 4.60 & 39.87 & 101.83 \\
\hline & 55.65 & 0.09 & 1.24 & 4.30 & 39.31 & 100.59 \\
\hline${ }^{-3-4}$ & 61.82 & 0.10 & 0.00 & 0.57 & 38.86 & 101.35 \\
\hline 5711521-1-4 & 55.46 & 0.09 & 1.74 & 3.77 & 39.32 & 100.38 \\
\hline & 61.82 & 0.10 & 0.03 & 0.30 & & 100.93 \\
\hline & 61.28 & 0.11 & 0.09 & 0.81 & 38.82 & 101.11 \\
\hline $\begin{array}{l}-3-4 \\
-3-5\end{array}$ & 56.50 & 0.16 & 1.49 & 3.36 & 39.41 & 100.92 \\
\hline $571121-3-5$ & 61.62 & 0.12 & 0.05 & 0.51 & 38.76 & 101.06 \\
\hline $571121-2-7$ & 51.99 & 0.11 & 0.28 & 8.59 & 39.37 & 100.34 \\
\hline $\begin{array}{r}571193-1-7 \\
-1-9\end{array}$ & 59.96 & 0.22 & 0.19 & 1.09 & 38.40 & 99.86 \\
\hline & 60.15 & 0.31 & 0.13 & 0.83 & 38.30 & 99.72 \\
\hline $\begin{array}{l}-1-10 \\
-1-11\end{array}$ & 59.67 & 0.61 & 0.22 & 0.88 & 38.32 & 99.70 \\
\hline $571145-2-11$ & $\begin{array}{l}59.66 \\
59.93\end{array}$ & 0.19 & $\begin{array}{l}0.16 \\
0.11\end{array}$ & $\begin{array}{l}0.59 \\
1.63\end{array}$ & $\begin{array}{l}37.77 \\
38.70\end{array}$ & $\begin{array}{r}98.37 \\
100.57\end{array}$ \\
\hline 5711109 (c) $-3-3$ & 61.68 & 0.24 & 0.03 & 0.47 & 38.82 & 101.24 \\
\hline $\begin{array}{l}-4-4 \\
0\end{array}$ & $\begin{array}{l}01.06 \\
61.73\end{array}$ & 0.20 & 0.00 & 0.11 & 38.51 & 100.55 \\
\hline $5711505-1-1$ & $\begin{array}{l}31.97 \\
31.97\end{array}$ & 0.13 & 1.29 & 25.25 & $\begin{array}{l}41.14 \\
41.31\end{array}$ & 99.78 \\
\hline & 32.48 & 0.14 & 1.32 & 25.29 & 41.52 & 100.75 \\
\hline$-1-4$ & 30.91 & 0.10 & 1.22 & 26.73 & 41.55 & 100.51 \\
\hline & & 0.13 & 1.62 & 16.98 & 39.79 & 98.20 \\
\hline $571118-2-7$ & 47.24 & 0.14 & 0.06 & 12.36 & 39.16 & 98.96 \\
\hline & & 0.18 & 0.08 & 11.68 & 39.71 & 100.56 \\
\hline$-3-6$ & & 0.15 & 0.05 & 11.88 & 39. & 99.38 \\
\hline $571148-3-5$ & 56.82 & 0.12 & 0.08 & 4.80 & 39.18 & 101.00 \\
\hline $571159-1-5$ & 56.14 & 0.12 & 0.64 & 3.81 & 38. & 99.30 \\
\hline & 56.92 & 0.16 & 1.46 & 3.50 & 39.75 & 101.79 \\
\hline$\frac{\text { Tsutsumi }}{58052015-3-3}$ & 53.34 & $0.49 \quad \longrightarrow$ & 4.51 & 1.01 & 39.11 & $98,46 \quad>$ \\
\hline
\end{tabular}

* : showing wurtzite-like optical properties.

* : The data were calculated assuming mineral stoichiometry and a perfect electron microprobe analysis.

* : The data were reduced with the fixed stoichiometry mode with $\mathrm{C}=\mathrm{Mn}+\mathrm{Ca}+\mathrm{Mg}+\mathrm{Fe}$. 


\section{Appendix II.}

Atago

Dainichizawa

Fukadani

Fukumaki

Furujuku

Furumiya

Hagidaira

Hamayokogawa

Hanawa

Hata

Hazu

Hijikuzu

Hokkōji

Hongō

Inakuraishi

Ioi

Iwato

Jūniyashima

Kaso

Kinkō

Konakayama

Kuranosawa

Kuratani

Kurosakaishi

Kurumazawa

Kusugi

Kyūrasawa

Mitsune

Mizutani

Mogurazawa

Mori

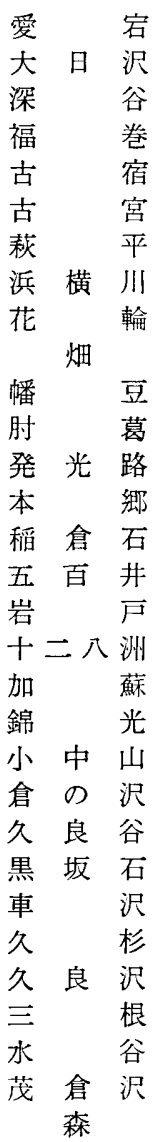

Nakanoyama

Namiita

Nishikata

Nodatamagawa

Nomine

Ōe

Ōidani

Ōishi

Ōmori

Ritō

Sankei

Sanyō

Shimozuru

Shōwa

Taguchi

Takahira

Takamatsu

Takanosu

Takashima

Taki

Tamamori

Tennō

Toyoka

Tsutsumi

Wagi

Yaei

Yagisawa

Yakumo

Yamada

Yamanaka

Yūbaridake
中野山

浪板

西方

野田玉川

野峯

大 江

大伊谷

大 石

大 盛

利東

三 恵

三 陽

下 鶴

昭 和

田口

高 平

高松

鷹 单

高島

滰

玉 盛

天 尾

豊 稼

堤

和 木

弥栄

八木 沢

八 䇗

山田

山中

夕張 岳 